\title{
Planning and Dealing: Piecemeal Land Controls as a Problem of Local Legitimacy
}

\author{
Carol M. Rose
}

\section{TABLE OF CONTENTS}

PAGE

I. Plan Jurisprudence as Reform ................... 848

A. The Assertion of Judicial Control over Piecemeal

Changes .................................... 848

1. Traditional Planning Law and Plan Jurisprudence.. 848

2. The Fasano Case ......................... 851

B. The Federahist No. 10 and Local Land Decisions ..... 853

C. A Historical Excursion into Plan Jurisprudence: Of

Variances and Referenda...................... 857

1. Variances and the Quasi-Judicialization of Land Use Decisions .............................. 857

2. Referenda and the Problem of Controlling Majoritarian Rule .......................... 863

II. Problems in Plan Jurisprudence ................. 867

A. The Treatment of Local Governmental Decisions as Quasi-Judicial .............................. 867

B. Finding the Line Between Legislative and Quasi-Judicial Decisions ..................................... 870

C. Is the Plan Really a Standard?.................. 873

1. Modern Planning Doctrine .................... 874

2. The Pattern of Local Practice ................. 879

III. Alternative Traditions, Alternative Approaches .. 882

A. The Local Context: Alternative Bases of Legitimacy... 882

B. Piecemeal Changes as Property Disputes: Mediation as a Resolution Process .............................. 887

IV. An Alternative Jurisprudence: Piecemeal Changes as Mediation ................................... 893

A. Due Consideration as Voice .................... 894

1. Identification of Disputants and Sources of Disputes.................................. 894

2. Exploration of Issues ...................... 896 
[Vol. 71:837

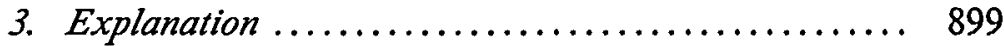

B. Fairness and Exit .......................... 900

1. Fairness as a Distributive or Redistributive Restraint ............................... 901

2. From Redistributive Fairness to Predictability:

Lessons from the Market-Mimicking Model....... 903

Conclusion: Why Local Land Use Control?............. 910 


\title{
Planning and Dealing: Piecemeal Land Controls as a Problem of Local Legitimacy
}

\author{
Carol M. Rose $\dagger$
}

Land use control in America has always been an intensely local area of the law. Modern land use law, with its roots in the turn-of-thecentury City Beautiful movement, was intended to deal especially with the growing population concentrations of urban localities. ${ }^{1}$ From the beginning, those localities and their governments were implicitly deemed the appropriate agencies for planning and ordering the physical development associated with their own startling growth. ${ }^{2}$ But during the last two decades, judges and legal scholars have shown mcreasing doubt that local governments make land development decisions fairly and rationally - that is, with a reasonable distribution of burdens among individuals, and with the care and deliberation commensurate with the long-term implications of land developinent. ${ }^{3}$

$\dagger$ Visiting Professor of Law, Northwestern University School of Law. Acting Professor of Law, Boalt Hall School of Law, University of California, Berkeley. B.A. 1962, Antioch College; M.A. 1963, University of Chicago; Ph.D. 1969, Cornell University; J.D. 1977, University of Chicago School of Law. A number of people have read and commented on earlier drafts of this paper. For their very helpful criticisins and suggestions I owe special thanks to Steve Barnett, Robert Ellickson, David Feller, Willy Fletcher, Gerald Frug, Toin Grey, Plyllis Palmer, Len Rubinowitz, and Sho Sato. All errors, of course, are purely iny own.

1. See, e.g., Baker, Zoning Legislation, 11 CORNELL L.Q. 164 (1926); Young, City Planning and Restrictions on the Use of Property, 9 MiNn. L. REv. 518, 519-20 (1925); see also Village of Euchd v. Ambler Realty Co., 272 U.S. 365, 386-87 (1926).

2. Baker, supra note 1, at 166; M. Scott, American City Planning Since 1890, at 101 (1969).

3. The idea of fairness as a matter of even distribution of burdens does not seem to have changed substantially in recent years. Compare Pennsylvania Coal Co. v. Mahon, 260 U.S. 393, 416 (1922), with Agins v. City of Tiburon, 447 U.S. 255, 260 (1980). But the idea of rationality has changed somewhat more. Perlaps under the influence of law and econonrics thinking, commentators have increasingly focused "rationality" discussions on the issue of efficiency; that is, a rational regulation is one, roughly speaking, whose benefits outweigh its costs. See, e.g., Michelman, Property, Utility, and Fairness: Comments on the Ethical Foundations of "Just Compensation" Law, 80 HaRv. L. Rev. 1165, 1215 (1967); Weisbrod, Conceptual Perspective on the Public Interest, in PubLIC INTEREST LAW 4 (B. Weisbrod ed. 1978). Because of the difficulties of assessing costs and benefits in environmental issues, such as land use, see infra notes 288, 319 and accompanying text, I use "rational" to mean "careful" or "duly considered," and thus address efficiency only indirectly, in that a carefully cousidered ineasure is likely to be efficient. The courts also normally treat the efficiency issues only indirectly, leaving cost-benefit analyses to regulatory bodies at least initially on the assumption that those bodies are institutionally competent to weigh costs and benefits carefully. See infra notes 58-62 (legislative competence) \& 130-32 (administrative conpetence), On "institutional competence," see Freedman, Book Review, 43 U. CHI. L. Rev. 307 
This doubt stems from several causes and takes different forms. Much of the criticism concentrates on the extralocal effects of local land use decisions, particularly the exclusion of low imcome outsiders, and the shifting of environmental problems to neighboring communities. ${ }^{4}$ But an older criticisin has cut even deeper, and is the subject of

(1976) (reviewing S. Barber, The Constirution and the Delegation of Congressional POWER (1975)).

4. The increased vulnerability of local land regulations is attributable in part to the civil rights movement and antipoverty efforts of the 1960's. These efforts focused attention on the cumulative consequences of what had until then seeined to be benevolent land controls: local "tight hittle islands," in their over-concentration on adequate space and on capacious and wellbuilt single family hoines, $m$ effect used land decisions to exclude the minorities and the poor who could only afford more modest quarters. R. BABCOCK, THE ZONING GAME 58-59, 149-52 (1966); Sager, Tight Little Islands: Exclusionary Zoning, Equal Protection and the Indigent, 21 STAN. L. REv. 767 (1969).

From a different perspective, environmentalism heightened national awareness of other consequences of local land use decisions allowing too much new developinent, e.g., downstream siltification, increased auto fumes, and the loss of historical landınarks and fragile ecosystems. See, e.g., R. Healy \& J. Rosenbero, LaNd Use and the STates $17-29$ (2d ed. 1979); F. Popper, The Politics of LaNd USE Reform 46-55 (1981); U.S. Council on ENVTL. QUality, THe QUiET ReVolution IN LAND Use CONTROL 1-3 (1971).

Civil rights and environmental complaints about local land decisions could easily be frained in the economists' language of "externalities," in that they focused on decisions that imposed costs on persons and resources outside the local boundarics. R. BABCOCK, supra, at 146; F. POPPER, supra, at 49. See Village of Arlington Heights v. Metropolitan Hous. Dcv. Corp., 429 U.S. 252 (1977) (refusal to rezone to permit an integrated housing project), on remand, 558 F.2d 1283 (7th Cir. 1977), cert. denied, 434 U.S. 1025 (1978); Umited States v. City of Black Jack, 508 F.2d 1179 (8th Cir. 1974) (zoning ordinance prohibiting multi-family dwellings), cert. denied, 422 U.S. 1042 (1975); Westfield-Palos Verdes Co. v. City of Rancho Palos Verdes, 73 Cal. App. 3d 486, 141 Cal. Rptr. 36 (1977) (environmental excise tax affecting housing projects); Daniels v. Borough of Point Pleasant, 23 N.J. 357, 129 A.2d 265 (1957) (exaction of tribute in the form of public improvements froin new developers and their new residents). See also City of Milwaukee v. Illinois, 451 U.S. 304 (1981) (dumping of local sewage into other cities' drinking water); Illinois v. City of Milwaukee, 406 U.S. 91 (1972); Ellickson, Suburban Growth Controls: An Economic and Legal Analysis, 86 YALE L.J. 385, 429, 475-89 (1977) (developinent changcs). In all these instances, the outsiders had to pay the costs of local land use decisions, without sharing the benefits or having any say in selecting the decisionmakers. For the critics, such instances showed the nced for sharper supervision by legislatures and courts over parochial, ill-considered, or self-serving local land decisions. R. BABCOCK, supra, at 154-74; Delogu, The Dilemma of Local Lond Use Control: Power Without Responsibility, 33 ME. L. Rev. 15 (1981); U.S. COUNCIL ON ENVTL. QUALITY, supra, at 3; see also R. HEALY \& J. RoseNBERG, supra, at 7-13; F. POPPER, supra, at 15-16.

To cope with these extra-local spillover effects, some state legislatures have responded in the last decade with a "Quiet Revolution" in land use statutes, bringing much greater state oversight over local regulations. The name comes from U.S. Council on ENvTL. QuaLITY, supra. For inore recent descriptions of these state and regional programs, see R. HeAlY \& J. Rosenbero, supra, and F. POPPER, supra. Such statutes, together with far-reaching court decisions in soine jurisdictions have imposed a new duty on local governments to match their planning and regulations to wider regional and state needs. See, e.g., Associated Home Builders of the Greater Eastbay, Inc., v. City of Livermore, 18 Cal. 3d 582, 557 P.2d 473, 135 Cal. Rptr. 41 (1976) (injunction against ordinance prohibiting future building permits); Southern Burlington County NAACP v. Township of Mount Laurel, 67 N.J. 151, 336 A.2d 713, appeal dismissed and cert. denied, 423 U.S. 808 (1975); Berenson v. Town of New Castle, 38 N.Y.2d 102, 341 N.E.2d 236, 378 N.Y.S.2d 672 (1975). 
this Article. It is that we need a new jurisprudence of local land decisions, not because of the external consequences of those decisionsserious though they may be-but because local governments cannot be trusted to deal fairly or carefully even in land decisions with only local consequences. ${ }^{5}$

Since the middle 1960 's, legal scholars have complained that local land decisions can make a mockery of orderly and predictable planned development. Individual land decisions, the critics say, amount to deals with landowners and developers; these deals gut the local plan (if indeed any exists) and are merely ad hoc impulse choices that neither safeguard the surroundings for present and future residents, nor enable those residents and would-be developers to predict future actions. ${ }^{6}$

These critics object most to the piecemeal changes in local land regulations: the all-pervasive "variance,"7 the "conditional use permit," 8 or the small-scale "rezoning" ordmance." These small adjustments are the everyday fare of local land regulations. Whatever the formal designation, any of these ad hoc adjustments alters preexisting general regulations governing the use of some individual parcel or other finite area within the community. Each such change is small on its face, appearmg to have little effect outside the immediate community and to concern only the individual developer, the neighboring owners, and the local government.

5. On judicial suspicion of local decisionmaking, see D. MANDELKER, The ZoNing DILEMMA 104 (1971); Sullivan, From Kroner to Fasano: An Analysis of Judicial Review of Land Use Regulation in Oregon, 10 WILLAMETTE L.J. 358, 364-66 (1974); Tarlock, Consistency with Adopted Land Use Plans as a Standard of Judicial Review: The Case Against, 9 URB. L. ANN. 69, 75, 88-101 (1975).

6. See, e.g., R. BABCOCK, supra note 4, at 7-16, 130-33; Heyman, Innovative Land Regulation and Comprehensive Planning, 13 SANTA Clara Law. 183, 187-200 (1972). See also R. ELLICKSON \& D. TARLOCK, LAND USE CONTROLS $234-76$ (1981) (refering to pattern of zoning changes as "dealmaking"); NAT'L INST. OF LAW ENFORCEMENT \& CRIMINAL JUSTICE, U.S. DeP'T of JUSTICE, AN ANALYSIS OF ZoNing Reforms: Minimizing the InCENTIVES for CorrupTION 6 (1979) ("negotiated zoning" a source of corruption) thereinafter cited as MiNIMIZING THE INCENTIVES FOR CORRUPTION].

7. A variance is in theory an exception to a zoning regulation granted where, because of circumstances unique to a particular property, strict enforceinent of the existing regulation would cause special hardship. In practice they have often been freely granted. See generally D. Hagman, Urban Planning and Land Development Control Law 196-206 (1971).

8. A "conditional use" or "special" permit allows a structure or use not permitted as of right within a given zone, but foreseen as permissible in limited numbers or with special conditions within that zone. For example, a church inay be allowed within a residential zone as a "conditional use." See generally D. HAGMAN, supra note 7, at 206-11. The discretionary character of such special permits makes them attractive to inunicipalities wishing to exercise case-by-case control. For one inunicipality's unsuccessful effort to require virtually all development to proceed via conditional use permits, see People v. Perez, 214 Cal. App. 2d Supp. 881, 29 Cal. Rptr. 781 (App. Dep't Super. Ct. 1963).

9. Such ordinances are normally amendinents to more general zonimg ordinances. See, e.g., Fritts v. City of Ashland, 348 S.W.2d 712 (Ky. 1961). 
The problem with these small changes, critics charge, is that they are so difficult to control. Judicial review of small changes is limited. Traditionally, they were tested only withm the ample girth of a loose reasonableness standard. ${ }^{10}$ This was particularly true where individual properties were reciassified through actual amendments to the ordinances; these rezonings, as "legislative" acts, were insulated froun close review by the courts, which required only that they not be arbitrary. ${ }^{11}$ But the arbitrariness standard cannot really control small changes. It is too broad to treat seriously the fairness claims of the individual property owners with interests at stake in piecemeal changes, and it fails to account for the cumulative effect of many nonarbitrary decisions that seem to shave away, in salami slices, any larger concepts underlying the origmal, more general land regulations.

Thus, the traditional legislative reasonableness standard is inadequate to assure fairness and due consideration. Minor regulatory changes seem impervious to other, nonjudicial controls as well, including most of the land use reforn ideas of the last decade. The state and regional controls in the so-called "Quiet Revolution" statutes are meant to monitor only the regional impact of local changes, not to disturb local discretion over individual parcel changes lacking wider ramifications. ${ }^{12}$ Similarly, new state statutes requiring environmental review of proposed changes only add to local discretion over piecemeal

10. 4 R. ANDerson, American Law of Zoning \$ 25.26 (1977). See also Bryden, Zoning: Rigid, Flexible, or Fluid?, 44 J. URB. L. 287, 301 (1967); Griffin \& Becker, Zoning, Kentucky Law Survey, 67 KY. L.J. 627, 655-56 (1978-79).

11. Village of Euclid v. Ambler Realty Co., 272 U.S. 365, 395 (1926). Permissive substantive and procedural standards are also applied in variance and conditional use decisions. See $3 \mathrm{R}$. ANDERSON, supra note $10, \S 20.01$.

It is noteworthy that the designation "legislative" las long troubled the courts. See, e.g., Borough of Creskill v. Borough of Dumont, 15 N.J. 238, 104 A.2d 441 (1954); Eves v. Zoning Bd. of Adjustment, 401 Pa. 211, 164 A.2d 7 (1960); see also Ward v. Village of Skokie, $26111.2 \mathrm{~d} 415$, 419-24, 186 N.E.2d 529, $531-32$ (1962) (Klingbiel, J., concurring). The older prohibitions on socalled "spot zoning" were often direeted at piecemeal clianges that appeared to give special privileges to a particular owner or property. See, e.g., Fritts v. City of Ashland, 348 S.W.2d 712 (Ky. 1961). See generally 1 R. ANDERSON, supra note 10, \& 5.11 (1976); Note, Spot Zoning and the Comprehensive Plan, 10 SYRACUSE L. REv. 303 (1959). Many courts lave noted that decisions revolving around highly individual ownership interests hardly fit the normal conception of generalized legislation. See, e.g., Hyson v. Montgomery County Council, 242 Md. 55, 67, 217 A.2d 578, 585 (1966).

12. For remarks on the Quiet Revolution, see supra note 4. Contimued local predominance is acknowledged even by the chief spokesmen for the Quiet Revolution. See U.S. CouNCIL oN ENVTL. Quality, supra note 4, at 3. See also R. Healy \& J. Rosenberg, supra note 4, at 133-34, 251; R. Linowes \& D. Allensworth, The States and Land-Use Control 47 (1975); DeGrove, The Political Dynamics of the Land and Growth Management Movement, 43 LAw \& ConTEmP. Probs. 111, 140 (1979); Pelhain, Regulating Developments of Regional Impact: Florlda and the Model Code, 29 U. FLA. L. REv. 789, 803, 814-15 (1977).

Indeed, the ultimate impact of the "Revolution" inay be to strengthen the local grip on land regulation. Callies, The Quiet Revolution Revisited, 46 J. AM. PLAN. Ass'N 135, 136, 139 (1980). 
changes, ${ }^{13}$ and in the view of one commentator even serve to legitimize ad hoc local decisions. ${ }^{14}$ Another set of ideas, the self-styled "deregulation" proposals, einbraces a variety of approaches, but they all envision a fairly high residue of local regulatory authority, and some even aim at freemg local discretion from state or regional supervision. ${ }^{15}$ Finally,

13. The first of these was California's Environmental Quality Act, CAL. PuB. Res. COdE $\$ \S 21000-21175$ (West Supp. 1982). For a discussion of local discretion under this and similar acts, see, for example, NAACP Santa Rosa-Sonoma County Branch v. Hills, 412 F. Supp. 102, 111-12 (N.D. Cal. 1976); Polygon Corp. v. City of Seattle, 90 Wash. 2d 59, 578 P.2d 1309 (1978). See generally DiMento, Citizen Environmental Litigation and the Administrative Process: Empirical Findings, Remaining Issues and a Direction for Future Research, 1977 DukE L.J. 409; DiMento, Citizen Environmental Legislation in the States: An Overview, 53 J. URB. L. 413 (1976); Pearlman, State Environmental Policy Acts: Local Decision Making and Land Use Planning, 43 J. AM. INST. PlanNers 42 (1977).

14. Hagman, NEPA's Progeny Inhabit the States-Were the Genes Defective?, 7 URB. L. ANN. 3, 35-36 (1974).

15. Perhaps the best-known and most persistent advocate of deregulation is Bernard Siegan. See B. Siegan, LANd USE Without Zoning (1972); Siegan, Non-Zoning in Houston, 13 J.L. \& EcoN. 71 (1970). See also Kmiec, Deregulating Lond Use: An Altemative Free Enterprise Development System, 130 U. PA. L. REv. 28 (1981) [heremafter cited as Kmiec, Deregulation]; Lefcoe, California's Land Planning Requirements: The Case for Deregulation, 54 S. CAL. L. REV. 447 (1981); Nelson, A Private Property Right Theory of Zoning, 11 URB. LAw. 713, 729 (1979) (favoring deregulation of undeveloped land). Deregulation is a misnomer for some of these proposals. Lefcoe's "deregulation" is largely directed against state imtrusions on local autonomy. Kmiec's "deregulation" is based explicitly on Henry George's "simgle tax" on real estate value, and would restructure local land use regulation into an in-kind taxation on the development value of land: developers would chose among a group of locally defined developinent models, and then provide public improvements at a value roughly equal to the difference between the developed and undeveloped value of the land. This siplioning off of development value hardly seems to give much comfort to the usual audience for deregulation. In addition, $\mathrm{Kmiec}$ contemplates considerable dickering between developers and local regulators. For a brief synopsis of his proposal, see Kmiec, The Role of the Planner in a Deregulated World, LAND UsE L. \& ZoNING Dig., June 1982, at 4. Siegan uses Houston as an example of a city without zoning, but Houston certainly has a variety of land use regulations. See B. SiEgAN, LAND USE Without ZoNING 26-33 (1972). Indeed, now that land control is moving imto previously unregulated rural counties and as Houston (once the Mecca of deregulators) lias finally adopted a zoning ordinance, deregulation seeins an unlikely vehicle for controlling local discretion in piecemeal changes. For Houston's current move toward zoning, see King, Houston's Council Tries to Control City Growth, N.Y. Tines, June 23,1982 , at $A 12$, col. 1. On the expansion of land use regulation in unincorporated areas, see Weber \& Peroff, Local Government Responses to State-Mandated Land Use Laws, 43 J. AM. INST. PLANNers 352 (1977). Deregulation takes another form in proposals for "enterprise zones," that is, high unemployment areas in which tax breaks and somc land use regulatory concessions are allowed in order to attract businesses. See generally Note, Enterprise Zones: New Life for the Inner City, 4 HARv. J.L. \& PUB. PoL'Y 243 (1981). Such schemes presuine thc continuation of land regulation outside the enterprise zones, however; otherwise regulatory rehef would have no appeal to the industries to be lured. Perliaps the inost important argunent for deregulation is that land use regulations raise the cost of housing. See Ellickson, The Irony of "Inclusionary" Zoning, 54 S. CAL. L. REv. 1167, 1188 (1981); Siegan, Regulating the Use of Land, in THE INTERACTION OF Economics AND LAW 159, 162-63 (B. Siegan ed. 1977); see also CAL. Gov'T CodE § 65583(4) (West Supp. 1983) (requiring local plans to include analysis of the "governmental constraints" on housing, including those imposed by land use regulation). In response to this argunent, the California legislature in 1981 passed a bill to establish five areas free of local land use controls, ostensibly to permit the developinent of low- and noderate-income housing without the impediments of local regulation. The bill was vetoed, however, amidst rumors of undue influence by a developer 
there is considerable academic mterest im proposals to reform local land use and control small changes by structuring regulations to copy a hypothesized market model of private transactions; but these proposals have not had great practical impact to date, perhaps because they would require a forbidding array of changes in current land use regulatory practice. ${ }^{16}$

How, then, to satisfy critics' charges that local governments make piecemeal changes unfairly and carelessly? The courts, urged on by academic commentators, have developed one much-discussed reform model to control these changes, which I call "plan jurisprudence." The model first postulates that some form of plan is necessary. Then, drawing heavily on administrative law doctrines, it regards all piecemeal changes as "judicial" or "quasi-judicial." According to this model, then, piecemeal land use decisions must conforin to standards set out in preexisting plans; moreover, because the individual decision applies a general standard to a specific mstance, the decision is to be inade according to adjudicative procedures.

As we shall see, plan jurisprudence has generated inuch discussion-particularly of its leading case, Fasano v. Board of County Commissioners ${ }^{17}$-but its actual influence has been limited. In some

who expected to gain from it. See Wiegard, Governor Vetoes 'New Cities' Bill, San Francisco Chron., Oct. 1, 1981, at 1, col. 6; Wiegard, Brown's Dilemma on 'New Cities,' id., Sept. 30, 1981, at 8, col. 1 .

16. The best known is Ellickson, Alternatives to Zoning: Covenants, Nuisance Rules, and Fines as Land Use Controls, 40 U. CH1. L. Rev. 681 (1973), which proposes a substitution of local "nuisance boards" for the present apparatus of zoning. Kmiec's "deregulation," dcscribed at supra note 15, is best seen as a market-mimicking proposal. Nelson proposes creation of a new market: he would recognize land use controls as a collective neighborhood property right and permit purchase and sale of such rights. R. NELSON, ZONING AND PROPERTY RIGHTS 173 passim (1977). See also Nelson, supra note 15.

The reform proposals in land use show a remarkable similarity to those in administrative law. See generally Stewart, The Reformation of American Administrative Law, 88 HARv. L. REv. 1667 (1975). Thus, the Quiet Revolution corresponds to reform proposals that Stewart dcscribes as revived "nondelegation doctrines," in that they impose greater central control through increased detail in authorizing statutes. Id. at 1693-97. State environmental impact requirements correspond to Stewart's "interest representation," which brings a wider range of interest groups into the regulatory process to counteract capture of an agency by regulated groups. Id. at 1723. See generally id. at 1711-800. "Deregulation" and "inarket-mimicking" proposals in land use reflect extensive corresponding proposals in administrative law. Id. at 1689-93, 1702-11. Much of this Article will deal with the doctrine requiring local governments to confonn their land decisions to preexisting plans. This too has an analogue in adninistrative law reform proposals for "structuring" discretion through the prior adoption of rules and plans. See id. at 1698-702.

17. 264 Or. 574, 507 P.2d 23 (1973). For commentary, see, for example, Freilich, Fasano v. Board of County Commissioners of Washington County: Is Rezoning an Administrative or Legislalive Function?, 6 URB. Law. vii (1974); Mandelker \& Netter, Comprehensive Plans and the Law, in LAND USE LAW: Issues for tHe Eighties 55, 56 (E. Netter ed. 1981); Sullivan, supra note 5; Sullivan \& Kressel, Twenty Years After: Renewed Significance of the Comprehensive Plan Requlrement, 9 URB. L. ANN. 33, 48-52 (1975); Webster, The Fasano Procedures: Is Due Process Enough?, 6 EnVtL. L. 139 (1975); Comment, Developments in the Lak-Zoning, 91 HARV. L. REv. 
jurisdictions it has been adopted completely; ${ }^{18}$ in others, it has been ultimately applied only in certain forms of piecemeal changes,; ${ }^{19}$ in still

1427, $1547-49$ (1978). For authorities recognizing Fasano as a leading case in a discretion-structuring approach to land decisions, see, for example, R. ElLICKson \& D. TARLOCK, supra note 6, at 78; MINIMIZING THE INCENTIVES FOR CORRUPTION, supra note 6, at 14-20 (1979); C. WEAVER \& R. BABCOCK, Ciry Zoning: The ONCE AND Future Frontier 271 (1979); Curtin \& Shirk, Land Use, Planning and Zoning, 9 URB. LAw. 724,739 (1977); Kolis, Zoning Amendments: Legislative vs. Quasi-Judicial Hearings, URB. LAND, July-Aug. 1979, at 24. Several cases before Fasano, lowever, also saw zoning amendments as quasi-judicial. See City of Louisville v. McDonald, 470 S.W.2d 173 (Ky. 1971); Hyson v. Montgomery County Council, 242 Md. 55, 217 A.2d 578 (1966); Fleming v. City of Tacoma, 81 Wash. 2d 292, 502 P.2d 327 (1972).

18. Oregon's legislature has now incorporated the Fasano plan jurisprudence approach into its land use enabling statutes. OR. REv. STAT. $\$ \S 227.160-180$ (1981). Kansas adopted the Fasano approach to zoning annendments in Golden v. City of Overland Park, 224 Kan. 591, 584 P.2d 130 (1978). Kentucky courts adopted a quasi-judicial approach to some zoning clianges even before Fasano. See City of Louisville v. McDonald, 470 S.W.2d 173 (Ky. 1971). Washington courts have taken the same line, see Barrie v. Kitsap County, 93 Wasl. 2d 843, 852, 613 P.2d 1148, 1153 (1980); Parkridge v. City of Seattle, 89 Wasl. 2d 454, 460-61, 573 P.2d 359, 363 (1978) (citing Fasano), but are somewhat less stringent about the plan as a standard, see Barrie, 93 Wash. $2 \mathrm{~d}$ at 850, 613 P.2d at 1152. See also Citizens Ass'n of Georgetown, Inc. v. District of Coluunbia Zoning Conm'n, 402 A.2d 36, 4 l (D.C. 1979) (rezoning decision must be supported by substantial evidence); Town v. Land Use Comm'n, 55 Hawaii 538, 546-48, 524 P.2d 84, 89-91 (1974) (rezoning decision is quasi-judicial action under state administrative procedure act).

19. See Arnel Dev. Co. v. City of Costa Mesa, 28 Cal. 3d 511, 620 P.2d 565, 169 Cal. Rptr. 904 (1980) (reversing lower court opinion which cited Fasano in holding rezonings- here by initiative-to be "quasi-judicial"); see also Ensign Bickford Realty Corp. v. City Council, 68 Cal. App. 3d 467, 137 Cal. Rptr. 304 (1977). The California courts, however, have held other piecenneal changes to be quasi-judicial. Horn v. County of Ventura, 24 Cal. 3d 605, 596 P.2d I134, 156 Cal. Rptr. 718 (1979) (subdivision approvals); Patterson v. Central Coast Regional Comm'n, 58 Cal. App. 3d 833, 130 Cal. Rptr. 169 (1976) (coastal zone developinent permit); City of Fairfield v. Superior Court, 14 Cal. 3d 768, 537 P.2d 375, 122 Cal. Rptr. 543 (1975) (planned unit developinent); Topanga Ass'n for a Scenic Community v. County of Los Angeles, 11 Cal. 3d 506, 522 P.2d 12, 113 Cal. Rptr. 836 (1974) (en banc) (variance). See generally Mountain Defense League v. Board of Supervisors, 65 Cal. App. 3d 723, 728, 135 Cal. Rptr. 588, 590 (1977) (decision is quasijudicial when it determines specific rights under existing law based on specific facts).

The Michigan Supreme Court briefly adopted the quasi-judicial approach to piecemeal rezoning amendments, but changed its mind in Kirk v. Township of Tyrone, 398 Mich. 429, 247 N.W.2d 848 (1976) (discussing earlier cases). Judge Levin led the effort to quasi-judicialize such decisious; he approved judicial proceedings to determine the reasonableness of proposed changes, but rejected plan consistency as a standard. See Sabo v. Township of Monroe, 394 Mich. 531, 232 N.W.2d 584 (1975); Kropf v. City of Sterling Heights, 391 Mich. 139, 164, 215 N.W.2d 179, 190 (1974) (Levin, J., concurring); see also Cunningham, Rezoning by Amendment as an Administrative or Quasi-Judicial Act: The "New Look" in Michigan Zoning, 73 MicH. L. Rev. 1341, 1344 (1975); Cunningham, Reflections on Stare Decisis in Michigan: The Rise and Fall of the "Rezoning as Administrative Act" Doctrine, $75 \mathrm{MICH}$. L. Rev. 983, 985-87 (1977). For the most recent argument in the Michigan court on this subject, see Ed Zaagnıan, Inc. v. City of Kentwood, 406 Micl. 137, 277 N.W.2d 475 (1979) (rejecting quasi-judicial approach).

The Colorado Supreme Court also adopted the Fasano approach to rezonings in Snyder v. City of Lakewood, 189 Colo. 421, 542 P.2d 371 (1975), but has backed away from it insofar as it would remove rezonings froin "legislation" subject to referenda. See Margolis v. District Court, 638 P.2d 297 (Colo. 1981). See also Kelly, Comment on Margolis, Wright, Young, Land UsE L. \& ZoNing DiG., Mar. 1982, at 14.

The Minnesota Supreine Court in State v. City of Rocliester, 268 N.W.2d 885 (Mnin. 1978) lias also rejected the Fasano approach (by name) for rezoning amendenents, but adopts a quasijudicial approach for other pieceineal changes. In Rochester, the court distinguislied "special use 
others, it has been rejected entirely. ${ }^{20}$ Newer statutes have been similarly mixed: the American Law Institute's Model Land Development Code calls for the quasi-judicialization of piecemeal changes, but is ambiguous as to plan conformity. ${ }^{21}$ On the other hand, some new state statutes mandate planning and "consistency" of land regulations with plans, but are silent as to the quasi-judicial character of individual decisions. ${ }^{22}$

These hesitations about plan jurisprudence suggest it may have both practical and theoretical defects, and that it may not ensure that local land use decisions are fair and careful. In this Article I will argue that plan jurisprudence fails to solve the problems it sets out to ineet, and instead creates new ones, particularly by its advocacy of an outmoded version of local land planning. We need some other approach to test the reasonableness of these decisions.

My thesis is that piecemeal local land decisions should not be classed as either "legislative" or "judicial"; these rubrics are drawn from a separation-of-powers doctrine more appropriate to larger governmental units. Piecemeal changes are quintessentially local matters, and any jurisprudential test of the reasonableness of piecemeal changes must identify and build upon the factors that lend legitimacy and imstitutional competence to local decisionmaking. In this Article I undertake that task. I will begim by analyzing plan jurisprudence, so as to point out its flaws and to draw on its merits. In Part I, I discuss the assertion of judicial control over piecemeal changes, especially in plan jurisprudence's ideal type, Fasano, and then explore The Federalist No. 10 as a doctrinal background for Fasano's underlymg suspicion of the vahidity of local land decisions. I will then trace the specific development of plan jurisprudence froin some specialized issues in zoning im the 1950's and 1960's, issues that crystallized Federalist-type objections to local decisionmaking by illuminating certain problems of fairness and due consideration in local land decisions.

permits," which are quasi-judicial under the rule of Zylka v. City of Crystal, 283 Minn. 192, 167 N.W.2d 45 (1969), and rejected the plaintiff's argument that rezoning amendments and special use permits were functional equivalents. 268 N.W.2d at 888-89. More tentatively, Texas also regards rezoning amendments as legislative, but sees variances and special exceptions as "perhaps quasijudicial" administrative acts. See Board of Adjustment v. Leon, 621 S.W.2d 431, 436 (Tex. Civ. App. 1981). Cf. Harris, Rezoning-Should It Be a Legislative or Judicial Function?, 31 BAYLOR L. REv. 409 (1979) (urging that Texas courts should follow Fasano and treat rezonings as adjudicative functions).

20. See, e.g., Hall Paving Co. v. Hall County, 237 Ga. 14, 226 S.E.2d 728 (1976) (per curiam) (rezoning ordimances require no findings of facts or conclusions). For the Minnesota view, see supra note 19.

21. Model LAND Dev. CODE $\$ \S 2-201$ (3), 2-304 \& note, 2-312(2), (3), 3-101 \& note 2 (1975).

22. See, e.g., FLA. STAT. ANN. $\$ \S 163.3167$ (mandatory planning), 163.3194 (consistency) (West Supp. 1983). For a review of mandatory planning and consistency statutes and decisions thereunder, see Mandelker \& Netter, supra note 17. 
In Part II, I will analyze in detail plan jurisprudence as a solution to those problems of fairness and due consideration, and will conclude that it is seriously flawed both in its procedural characterization of local land decisionmaking as quasi-judicial, and in its substantive reliance on the plan as a standard.

Then, in Part III, I will attempt to salvage the chief merit of plan jurisprudence, its recognition that we need a theory to legitimize local decisionmaking, particularly when the locality decides what are essentially conflicting property claims. In this Part, I outline a non-Federalist tradition that identifies the pecuharly local claim to legitimacy in two factors that the economist Albert Hirschman calls "voice" and "exit": the opportunity to participate, or to go elsewhere. ${ }^{23}$ I will go on to analyze local piecemeal changes as mediations of property disputes.

In Part IV, I will use these ideas - as well as those of other land use reform proposals-to develop an alternative jurisprudence of piecemeal changes. This jurisprudence treats piecemeal changes as dispute mediations, and tests fairness and due consideration in the light of the local opportunity for participation or departure. I attempt to develop standards that refine the processes local governments actually use, that encourage the use of up-to-date planning techniques, and that generally heighten the institutional competence of these local decisions. ${ }^{24}$ Finally, in the Conclusion I comment on why land use decisions have invariably been committed to local governments.

As may already be obvious, this Article makes several presuniptions. First, I presnme that the jurisprudence of land decisions is bound to fail unless it takes account of how these decisions are actually made. Given the constitutionality of local land use controls, ${ }^{25}$ and the likelihood of their continued and even expanded use, ${ }^{26}$ such a jurisprudence should attempt to clarify and refine actual practice. This in turn suggests not only an inquiry into local institutional legitimacy, but also a direct approach to the "dealing" characteristics of local land controls. Second, I presume that a jurisprudence of local land controls should not distort nodern thinking about land planning, but should rather incorporate and encourage innovative planning and land regulation. And finally, I presnme that such a jurisprudence should not unnecessarily disrupt the existing judicial imterpretations of piecemeal change, but should rather build on their insights about this form of resolving disputes. Hence I frame my proposals as a new version of the "reason-

23. A. Hirschman, Exit, Voice, and Loyalty (1970).

24. See Freedman, supra note 3.

25. Village of Euclid v. Ambler Realty Co., 272 U.S. 365, 388-90 (1926).

26. Mandelker \& Netter, supra note 17. 
ableness" standard of review, one that will genuinely promote fairness and care in local decisions.

Taking this conservative approach, I turn to plan jurisprudence as the current leading candidate for reform of piecemeal changes.

I

\section{Plan Jurisprudence as Reform}

\section{A. The Assertion of Judicial Control Over Piecemeal Changes}

Pieceineal changes in land use worry critics because they are hard to control. This Part looks at two ways in which plan jurisprudence seeks to control sinall changes. First, it examines judicial enforceinent of conformity to a plan. It then takes a historical look at how the plan itself became favored as a way of solving problems of fairness and due consideration.

\section{Traditional Planning Law and Plan Jurisprudence}

In administrative law, one well-known postulate is that adininistrative agencies, though they may retain wide discretion, should delimit that discretion, operating according to rules that they make for theinselves. ${ }^{27}$ An analogous view in land use law is that local governments should first set out a general land use plan, and then apply the plan's standards as they enact specific land use controls. ${ }^{28}$

The planning idea is not new, although it las only recently been taken seriously. In fact, the preference for "structured" land decisions harks back to one of the oldest methods of assurmg both fairness and due consideration in local land use regulation. The Department of Cominerce's Standard Zoning Enabling Act (SZEA), first published in 1922 and adopted by most states over the next few years, ${ }^{29}$ required that local land use controls be "in accordance witl" a general plan. ${ }^{30}$ This plan presumably would be created by the local planning comınission, whose inipartiality and technical expertise would ensure the dura-

27. See, e.g., Soglin v. Kauffiman, 418 F.2d 163, 167-68 (7th Cir. 1969); Hornsby v. Allen, 326 F.2d 605, 608 (5th Cir. 1964); see also K. Davis, Administrative Law Treatise $§ 2.00$ (Supp. 1976); K. DAVIS, DiscretionaRY JUSTICE 52-55 (1971).

28. See Bross, Circling the Squares of Euclidean Zoning: Zoning Predestination and Planning Free Will, 6 ENVTL. L. 97, 115 (1975), for a comparison of planning requirements with "rule refinement" doctrine in administrative law.

29. Standard State Zoning Enabling Act (U.S. Dep't of Commerce rev. ed. 1926) [hereinafter cited as SZEA], reprinted in MODEL LAND DEv. CODE app. A at 210-21 (Tent. Draft Nq. 1, 1968); Standard CitT Planning Enabling Act (U.S. Dep't of Commerce 1928), reprinted in MODEL LAND DEv. CODE, supra, app. B at 222-71. By the mid-1920's more than half the states had adopted it in whole or in part; by the early 1970 's, all but three had. Baker, supra note 1, at 170. See Krasnowiecki, Zoning Litigation and the New Pennsylvania Procedures, $120 \mathrm{U}$. PA. L. Rev. 1029, 1041 (1972). See also R. LINOWES \& D. ALLENsworTH, supra note 12, at 42-43.

30. SZEA, supra note 29, §3. See also Sullivan \& Kressel, supra note 17, at 36-47. 
bility and rationality of the overall plan. ${ }^{31}$ The plan, in turn, would ensure the rationality and stability of the ordinances that implemented it. It was widely assumed that localities could indeed set their goals far in advance, that changes in land regulation would therefore seldoin be necessary, and that citizens would not face fluctuations in the status of their own or their neighbors' land. ${ }^{32}$

But botl in law and in practice these assumptions proved false. The courts did little to establish advance planning as a legal prerequisite for local land regulation. They noted that the Standard Planning Enabling Act was issued several years after the SZEA, that it had been much less widely adopted, and concluded that state legislatures adopting the SZEA could not have ineant to require an independent plan as a prerequisite to local zoning. ${ }^{33}$ Following the example of the leading Supreme Court case of Village of Euclid v. Ambler Realty Co. ${ }^{34}$ courts regarded the zoning ordinances (and their amendinents) as "legislative" acts, which were to be uplield unless they were clearly arbitrary and unreasonable.

The idea of a plan as an independent control on local regulation only began to take hold in the 1950's, when federal urban aid programs began to require (and fund) local planning as a condition to grants-inaid. ${ }^{35}$ Even then, the courts were reluctant to require a plan as a prerequisite to actual regulation; well into the 1950's they routinely upheld zoning ordinances and amendments which disclosed soine "plan" in themselves. ${ }^{36}$

Experience also quickly confounded any expectation that stable regulations would flow automatically from well-considered long-term plans. Controls soon became ad hoc responses to individual development proposals. ${ }^{37}$ Local officials encouraged this pattern by zoning areas for uses less intense than those expected, then altering regulations on a parcel-by-parcel basis-sometimes after striking a bargain with the individual developer. ${ }^{38}$ The real estate industry understood this

31. M. ScotT, supra note 2, at 245.

32. See Heyman, supra note 6 , at 184.

33. For a discussion of this pattern, see Haar, "In Accordance with a Comprehensive Plan," 68 HARv. L. REv. 1154, 1157 (1955). See also Sullivan, supra note 5, at 362-64. Cf. SZEA, supra note 29.

34. 272 U.S. 365 (1926).

35. Sullivan \& Kressel, supra note 17, at 36 n.15, 47.

36. See $1 \mathrm{R}$. ANDERSON, supra note 10, §5.04, at 266-68 (1976); authorities cited id. A leading case is Kozesnik v. Township of Montgomery, 24 N.J. 154, 131 A.2d 1 (1957) (ordimance struck down on other grounds).

37. D. MANDELKER, supra note 5, at 103-04; R. Ellickson \& D. TARLOCK, supra note 6, at 58-59; see also Heyman, Legal Assaults on Municipal Land Use Regulation, 5 URB. L. 1, 2 (1973).

38. Model Land Dev. Code § 3-106 note, at 70-73 (Tent. Draft No. 1, 1968); id. art. 8 commentary, at 196-97; R. ELLICKSON \& D. TARLOCK, supra note 6, at 58-59. 
process well, and frequently conditioned land purchases on changes in existing zoning. ${ }^{39}$

As this pattern of land regulation through pieceineal changes becaine uncomfortably obvious, the idea of a plan to guide actual land decisions took on renewed force. Within the last decade, a number of states have begun to sharpen the older SZEA requirements by adoptimg mandatory planning statutes, and by requiring that local land use controls be "consistent" with local plans. ${ }^{40}$ These new planning statutes generally require local governments to plan, and inay even prescribe "elements" or subjects about which the local governments must have plans, but they set no substantive criteria against which to test the local plan. ${ }^{41}$

Even procedurally, they are general: they require each community to consider its own locally defined goals, and then to state those goals in such a way as to direct future decisions. Beyond this, the mandatory planning and the planning consistency statutes prescribe no particular procedure that the local government must follow.

It was the courts, rather than the legislatures, that first took a further procedural step and judicialized local land use regulations. That is, instead of seeing small changes as legislative acts that are judicially reviewable only for arbitrariness, courts began to say that im making changes, local governmental bodies were acting in judicial or quasijudicial capacities. ${ }^{42}$

39. This pattern appears frequently in the reported cases. See, e.g., HFH, Ltd., v. Superior Court, 15 Cal. 3d 508, 542 P.2d 237, 125 Cal. Rptr. 365 (1975), cert. denied, 425 U.S. 904 (1976); Town of Largo v. Imperial Hoines Corp., 309 So. 2d 571 (Fla. Dist. Ct. App. 1975); Manley v. City of Maysville, 528 S.W.2d 726 (Ky. 1975).

40. Sullivan \& Kressel, supra note 17, at 53-63; DiMento, Improving Development Control Through Planning: The Consistency Doctrine, 5 Colum. J. EnvTL. L. 1, 4 n.6 (1978); Hicks, New and Significant Decisions: The Interest Groups Involved in the Planning and Zoning Process, 1978 INST. ON PLAN. ZONING \& EMINENT DOMAIN 1, 13-26. For a breakdown of state statutes on mandatory planning and consistency, see Mandelker \& Netter, supra note 17, at 6-8. See also Note, Urban Planning and Land Use Regulation: The Need for Consistency, 14 WAKE FOREST L. REV. 81 (1978). California was among the first states to adopt mandatory planning and consistency legislation. For a discussion of California's consistency requirements, see DiMento, Developing the Consistency Doctrine: The Contribution of the California Courts, 20 SANTA Clara L. REv. 285 (1980).

41. See, e.g., CAL. Gov'T Code $\S 65302$ (West Supp. 1983). There are exceptions on specific subjects. California's inandatory planning statute, for example, requires that the "housing element" in local plans meet substantive regional goals for low incoine housing. CAL. Gov'T CODE $\$ \$ 65583-65584$ (West Supp. 1983). The tests of the other eleinents ask whether the planning process followed prescribed steps and collected sufficient data. See, e.g., Camp v. Mendocino County Bd. of Supervisors, 123 Cal. App. 3d 334, 176 Cal. Rptr. 620 (1981). See also Creative Displays, Inc., v. City of Florence, 602 S.W.2d 682, 683 (Ky. 1980). Tarlock criticizes "consistency" legislation as paying insufficient attention to the content of the plans themselves. Tarlock, supra note 5 , at $84,99-101$.

42. Golden v. City of Overland Park, 224 Kan. 591, 584 P.2d 130 (1978); City of Louisville v. 


\section{The Fasano Case}

Fasano v. Board of County Commissioners ${ }^{43}$ is the leading case in the quasi-judicialization of local land decisions. I use Fasano and its Federalist underpinnings to show how and why courts thought they should enforce conformity to a plan. This 1973 Oregon case involved a small change: the rezoning of a thirty-two acre parcel to permit mobile homes. According to the traditional jurisprudence of planning and zoning, the local council's rezoning ordinance would be cast as a "legislative" act, whatever the size or scope of the parcel rezoned; and as such it enjoyed a strong presumption of validity. ${ }^{44}$ But the Fasano court, clearly concerned that a local government's unrestrained discretion might lead to sweetheart deals with developers, rejected the traditional presumption favoring legislative acts. Instead, the court took an administrative law approach to the local decision, labelling this decision judicial rather than legislative.

The court's reasoning had two separate strands. The first, and more developed, concerned the nature of the piecemeal land decision itself; the second, the character of the decisioninaking body. As to the nature of the change itself, the Fasano court distinguished individual parcel rezonings from adoption of general plans or general land use controls. The latter are broad policy decisions, the court reasoned, and are properly viewed as legislative; but the former apply preexisting policy standards--embodied in the general plan itself-to an individual

McDonald, 470 S.W.2d 173 (Ky. 1971); Fasano v. Board of County Comm'rs, 264 Or. 574, 507 P.2d 23 (1973); Fleming v. City of Tacoma, 81 Wash. 2d 292, 502 P.2d 327 (1972) (en banc).

43. 264 Or. 574,507 P.2d 23 (1973). For commentary on the development of judicial control over land use, see authorities cited supra note 17.

44. Such rezonings, as "legislative" ordinances, are presumed to be valid, and are overturned only if arbitrary and capricious. See, e.g. , Hall Paving Co. v. Hall County, 237 Ga. 14, 226 S.E.2d 728 (1976) (per curiam); Rodgers v. Village of Tarrytown, 302 N.Y. 115, 96 N.E.2d 731 (1951); see also Cheney v. Village 2 at New Hope, Inc., 429 Pa. 626, 241 A.2d 81 (1968) (planned unit development). Implicitly contrary to the presumption of validity, however, was the longstanding (but theoretically uncertaim) restraint on small-scale rezonings as so-called "spot zones." See, e.g., Fritts v. City of Ashland, 348 S.W.2d 712 (Ky. 1961); Bucholz v. City of Omaha, 174 Neb. 862, 120 N.W.2d 270 (1963). See generally 1 R. ANDERSON, supra note 10, $\$ \$$ 5.08-.19, at 285-384. Some jurisdictions' courts developed fairly elaborate doctrines to protect residents against changes in zoning. The most notable example is Maryland. Here the courts have developed a doctrine whereby localities are required to justify changes in zoning by showing either a substantial change of condition since the original regulation, or a mistake in the original regulation; these decisions implicitly alter the presumption of validity of zoning ordinance amendments. See, e.g., Chapman v. Montgomery County Council, 259 Md. 641, 271 A.2d 156 (1970); MacDonald v. Board of County Comm'rs, 238 Md. 549, 210 A.2d 325 (1965); Wakefield v. Kraft, 202 Md. 136, 96 A.2d 27 (1953). But see the extensive critique in Barnes' dissenting opinions im MacDonald and Chapman. For a discussion of the influeuce of the Maryland cliange/mistake rule in a number of other jurisdictions, see Burke, The Change-Mistake Rule and Zoning in Maryland, 25 AM. U.L. REv. 631 (1976). See generally 1 R. ANDERSON, supra note $10, \S 5.07$. 
parcel. ${ }^{45}$ Such rezonings entail the consideration of what administrative law calls "adjudicative facts"-that is, specific details about specific properties brought forth by specially interested parties; and they entail the application of standards (i.e., the plan) to the facts presented. ${ }^{46}$ According to Fasano, such decisions are judicial rather than legislative. ${ }^{47}$ Therefore, in making these decisions, the local governmental body should operate with at least soine of the procedural trappings of a court: it should act as an impartial tribunal and receive no ex parte contacts; it should allow the interested parties to present and rebut evidence; it should inake decisions on a record, together with appropriate findings; judicial review of its decisions should be stricter than the traditional loose review for inere legislative arbitrariness, and should instead require substantial evidence to support the decision, with the burden on the local government to show plan conformity. ${ }^{48}$

In concluding that soine zoning ordinances were judicial rather than legislative, the Fasano court also suggested a second strand of reasoning, relating to the nature of the local decisionunaking body. The court rejected the argument that a local government's rezoning decision was legislative simply because it was undertaken by an elected council, and remarked that local governimg bodies could not be equated with state or national legislatures. ${ }^{49}$ Indeed, the court's bold recharacterization of the local ordinance depended on seeing the local decisionmaking body not as a full "legislature," but rather as soinething less. A full state or national legislature inay adopt legislation even on highly individualized subjects without special quasi-judicial hearings; these are required only of "subordinate bodies" such as administrative agencies.

This less developed strand of Fasano-the treatment of a local governing body as something less than a full legislature-is thus critical to its functional administrative law analysis of the local government's land regulations. But the court's discussion of this central issue is remarkably cryptic as to why a local representative body, at least in some

45. 264 Or. at 582-83, 507 P.2d at 26-27.

46. $1 \mathrm{~K}$. Davis, Administrative Law Treatise $\$ 7.02$ (1958). See also City of Louisville v. McDonald, 470 S.W.2d 173, 177-78 (Ky. 1971); Hyson v. Montgomery County Council, 242 Md. $2 d 55,64-65,217$ A.2d 578, 585 (1966).

47. 264 Or. at 581,507 P.2d at 26.

48. Id. at 583-84, 507 P.2d at 29-30.

49. Id. at 581,507 P.2d at 26.

50. Londoner v. City of Denver, 210 U.S. 373 (1908). In Anderson v. Board of County Comm'rs, 77 Kan. 721, 95 P. 583 (1908), the Supreme Court of Kansas, interpreting Minnesota's constitutional prohibition against special legislation, observed that when a legislature "acts upon a public bill, [it] legislates; when it acts upon a private bill, it adjudicates," id. at 731, 95 P. at 586 (quoting Orth, Special Legislation, 97 ATL. MONTHLY 69, 69 (1906)), but went on to comment on the prevalence of special legislation in state legislatures in the absence of constitutional limitations on such bills. 
of its decisions, is not a legislature but is more akin to an administrative body. ${ }^{51}$

It is all the more important to ask this question because Fasano so sharply intrudes imto the entire structure of local decisionmaking on land use matters. As I have argued, local governments from the outset had dealt with land development on a piecemeal, bargaining basis. In challenging and restructuring this bargaining process, Fasano broke with a pervasive pattern. ${ }^{52}$

Moreover, Fasano's challenge rests on a troublesome suspicion of local legislative bodies, ${ }^{53}$ and is related to a long line of legal doctrines that have limited the powers of local government - unduly so, in the eyes of some commentators. ${ }^{54}$ Let us then pursue that crucial undeveloped portion of Fasano: In what way is a local governing body not fully a legislature?

\section{B. The Federahist No. 10 and Local Land Decisions}

One reason that a local representative body is not a legislature is the mere fact of its subordination to a state governinent. Municipalities, after all, are creatures of the state rather than independent "sovereigns."55 But this answer is too easy. Fasano may have cited administrative law cases, but local governments are not merely administrative bodies that fill in the interstices of statutes passed by state legislatures, or that carry out preestablished state policies. Rather, they exercise wide police powers within their jurisdictions, at least insofar as state legislation is not preemptive. Indeed, many state constitutions guarantee the local powers of home rule against state legislative incursions. ${ }^{56}$ Moreover, local governing councils, like larger legislatures, are composed of elected representatives for fixed terms of office. Why, then, even despite subordination to state governunent, are local governments not "legislative" bodies?

As one pair of administrative law authors has said, the American

51. Anderson comments on other courts" failures to explain the "administrative" treatment of local governments' land use decisions, relating the failure to snspicion of local governments. 4 R. ANDERSON, supra note $10, \$ 25.06$, at 210 . See also MacDonald v. Board of County Comm'rs, 238 Md. 549, 586-88, 210 A.2d 325, 346-47 (1965) (Barnes, J., dissenting) (criticizing the "adninistrative" characterization of a local governing body).

52. See supra notes $37-38$ and accompanying text.

53. 4 R. ANDERSON, supra note 10, § 25.05, at 208-10.

54. See generally Frug, The City as a Legal Concept, 93 HARv. L. Rev. 1057 (1980).

55. See generally 1 E. MCQuillan, The LaW of Municipal Corporations $\$ \$ 1.38,2.08 a$ (3d rev. ed. 1971). In Community Communications Co. v. City of Boulder, 455 U.S. 40, 50-51 (1982), the Supreme Court recently reemphasized that localities are not "sovereign."

56. 2 E. MCQUILLAN, supra note $55, \S 9.08$. See generally Vanlandingham, Municipal Home Rule in the United States, 10 WM. \& MARY L. REv. 269 (1968). For a discussion of home rule authorization of local land use control, see R. ANDERSON, supra note 10, §§ 2.14-.18. 
understanding of governance through separate branches was "developed by Locke and Montesquieu and refined by Madison."57 Madison's chief refinement has to do precisely with the legislature, and with the qualities that inake a legislature's decisions fair and reliable. His celebrated The Federalist No. 10 inerits study here, for it suggests why a local elected government should not always be seen as a legislature.

Madison's essay begins with the argument that the chief obstacle to fairness im a legislative body is "faction": the tendency of one interest group to impose its will at the expense of others. ${ }^{58}$ The antidote to faction, Madison says, lies im a constituency of sufficient size and variety; The Federalist No. 10 argued that the great advantage of the "extended republic" (i.e., the proposed national government) was that it would contam such a variety of mterests that no one "faction" could tyrannize the others. ${ }^{59}$ Where the constituency is large, action is possible only through persuasion and coalitions of interest groups. Through a pattern of shifting alliances and vote trading, every imterest can obtain at least partial satisfaction in the legislature of the "extended republic." 60

Thiat all of the participatimg parties can expect some satisfaction of at least some of their desires is one assurance of fairness im legislation. Fairness is also advanced by the conditions that attend coalition-building itself: no interest group can safely go for the jugular of another, because all know that they may need to call on eacli otlier in different coalitions. Thus the very expectations built into the coalition-building process impose a modicum of mutual forbearance on the various interest groups. ${ }^{61}$

Hannah Pitkin, in her analysis of The Federalist No. 10, has stressed a second characteristic of its legislature, one that assures due consideration of the public interest: the clash of multiple interests pre-

57. S. Breyer \& R. Stewart, Administrative Law and Regulatory Policy 37 (1979). See also D. WalKer, Toward a Functioning Federalism 23-43, $227-28$ (1981). $351-53$.

58. The Federalist No. 10, at 56-57 (J. Madison) (J. Cooke ed. 1961); see also id. No. 51, at

59. Id. No. 10, at 63-65; see also id. No. 51, at 351-53.

60. A. Bickel, The Supreme Court AND the IdeA of Progress 37 (1970); Michelman, Political Markets and Community Self-Determination: Competing Judicial Models of Local Government Efficiency, 53 IND. L.J. 145, 173 (1977-78). For a practical example, see S. HAYs, CoNSER VATION AND THE GOSPEL OF EFFICIENCY 231-40 (1980) (tracing passage of the Rivers and Harbors Act). But see J. Ely, DEMOCRACY AND DisTRUST 80-88 (1980) (Madisonian plurahist coalitionbuilding model may not always protect minority imterests, even at the federal level). See also J. Buchanan \& G. Tullock, The Calculus of Consent: logical Foundations of ConstiTUTIONAL DEMOCRACY 131-45 (1962) (coalition-building model of legislative action leads to inefficient over-regulation or over-taxation so long as inmority voters are not compensated by winning coalitions).

61. The Federalist No. 10, at 63-64 (J. Madison) (J. Cooke ed. 1961); id. No. 51, at 352-53. 
vents hasty and ill-considered decisions and forces the legislators to take the time to reflect on the true public welfare. ${ }^{62}$ Because of these factors, then, the courts can safely trust the larger legislature to make fair and careful decisions under most circumstances, and can give broad leeway to those decisions.

But this justification of large legislatures' decisions contains an imphicit criticism of small-scale government: A legislative body drawn from too small or too homogeneous a constituency may be dominated by a simgle interest or faction. ${ }^{63}$ Factional domination may take varying forms. One is sheer corruption, made possible im smaller representative bodies because a limited number of persons have influence which inust be bought. ${ }^{64}$ Another possibility is domination by a few who are perceived by others as the powerful. The decisions of these few can affect many within the cominunity; others must curry their favor, and even larger interests find difficulty in organizing against their "cabals."65 Finally, and perhaps most feared by Madison, is the factional domination created by a popular "passion"-sometimes a sudden whim, sometimes a longstanding prejudice-that carries a majority before it. $^{66}$ Under any of these various forms of factional domination, all of which are far more likely to occur in a smaller legislature than in a larger one, a dominant group may subject others to sudden destruction or to permanent political disability.

In a small-scale government, then, there may be no clash of multiple interests leading to at least temporary stasis and ultimately to an

62. H. Pitkin, The Concept of Representation 195-96 (1967).

63. The Federalist No. 10, at 61-63 (J. Madison) (J. Cooke ed. 1961).

64. For a discussion of local corruption in land use regulation, see MINIMIZING THE INCENTIVES FOR CORRUPTION, supra note 6, at 1-13; see also NAT'L INST. OF LAW ENFORCEMENT \& Criminal Justice, Corruption in Land Use and Building Regulation (1979); Nelson, supra note 15, at 724 (1979); Shapiro, The Case for Conditional Zoning, 4 I TEMPLE L.Q. 267, 28283 (1968). Cf. Ellickson, supra note 4, at 405-10 ("influence" stronger in larger governments). Ellickson uses The Federalist as a basis for this argument, although it appears to contradict The Federalist's comments about the greater opportunities for corruption in smaller governments. See The Federalist No. 10, at 63-64 (J. Madison) (J. Cooke ed. 1961). See also 2 Debates IN tHe Several State Conventions on the adoption of the Federal Constitution 256-57 (J. Elliot ed. 1836) (Hamilton's comments on corruption in small-scale government in his remarks at the New York ratifying convention) [heremafter cited as Elliot].

65. The Federalist No. 10, at 62-64 (J. Madison) (J. Cooke ed. 1961); 2 Elliot, supra note 64, at 256-57 (Hamilton speeclr). For a discussion of faction in the contemporary Britisl Parliament and its influence on American thinkers, see B. BAILYN, THE ORIGINS OF AMERICAN POLIIICS 124-26 (1967). The danger of influence, or in 18th-century parlance "cabal," in local government is highlighted in Note, City Government in the State Courts, 78 HARv. L. Rev. 1596, $1598-99$ (1965). On the organizational problems of large groups vis-a-vis sinall groups, see M. Olson, The Logic of COLlective Action 28-29, 46-48, 53-57 (1965).

66. The Federalist No. 10, at 58-62 (J. Madison) (J. Cooke ed. 1961). See also Frug, supra note 54 , at 1072. 
adequate and careful consideration of the public well-being. ${ }^{67}$ Moreover, as Frank Michelman has recently suggested, there may not be enough items of political interest to permit the developınent of coalitions and the benefit-trading and mutual forbearance they entail. ${ }^{68}$ Thus, a local representative council cannot (or cannot always) be trusted to act with the "legislative due process" envisioned by The Federalist No. 10 in a larger legislature.

In a nation whose view of legislative legitimacy is so heavily influenced by Madison's arguments, ${ }^{69}$ local governments nay thus always be viewed with some bemusement or even suspicion. ${ }^{70}$ Indeed, several authors in recent years have argued, on Federalist considerations, that no local decisions are fully legislative (and hence presumptively valid) for purposes of judicial review. Because of the lack of multiple interests at the local level, these authors say, the imternal structure of local government fails to assure a sufficient regard for the interests of local minorities, whose support need never be sought by the stable local majorities. ${ }^{71}$

However much or little local governments may structurally reseinble the Federalist legislature in general, they are very unlikely to be restrained by the Federalist safeguards in making specific piecemeal land decisions. In making these decisions, which mvolve only a few imterested parties meeting only on single issues, legislatures are restrained neither by a coalition-building process that assures the fairness of the decisions, nor by a clasl of interests that gives time for sober consideration. Courts sliould therefore not assume that these safeguards have worked. If these decisions are to be found reasonable, the finding requires some alternative source of fairness and due consideration.

It seems, then, that any model suggestimg that local governments are just like larger legislative bodies is unrealistic. It follows that courts should not give local governments' ad hoc land decisions the deference they accord to ineasures taken by state legislatures. Fasano's plan ju-

67. H. PITKIN, supra note 62, at 195-96.

68. Michelman, supra note 60 , at 173-77. Not only is coalition-building in many local governments limited by the relatively sinall size of the local constituency, but in many areas special purpose districts even further reduce the range of issues on which coahtions can be formed in the local governmental process. See U.S. AdvisORY COMM'N ON INTERGovernMENTAL RELATIONS, The Problem of Special Districts in America (1964).

69. D. WALKER, supra 'note 57 , at $36-43,227-28$.

70. For a discussion of the longstanding suspicion of local government in Aınerica, see Frug, supra note 54, at 1067, 1106-12; see also J. ELY, supra note 60, at 80. For the same discussion in the context of local land regulation, see 4 R. ANDERSON, supra note 10, § 25.05.

71. Sandalow, The Limits of Municipal Power Under Home Rule: A Role for the Courts, 48 MinN. L. Rev. 643, 709-11 (1964); Waggoner, Log-rolling and Judicial Review, 52 U. CoLo. L. REv. 33, 43 (1980); Note, supra note 65, at 1597-99. 
risprudence attempts to solve the problem by agreeing that the local government is not a true legislature; rather, it is more like a court, and its decisions should therefore be made according to judicial standards. The substantive standards for these adjudicative decisions derive from the locahty's own plan; the procedures derive from the courts.

But the skittishness of soine jurisdictions about Fasano ${ }^{72}$ suggests that some courts find that quasi-judicialization is also mappropriate for controlling at least soine pieceineal changes, and that we should seek alternatives to plan jurisprudence. This Article will argue that the better approach is to abandon analogies to the separate branches, and to fashion tests of fairness and due consideration that are based directly on the "dealing" character of pieceneal changes. Before arguing this thesis, however, I shall examine the history of the recent revival of the plan as a device to structure and test local land use discretion, for that history clarifies the precise nature of the problems that modern plan jurisprudence attempts to address.

\section{A Historical Excursion into Plan Jurisprudence: Of Variances and Referenda}

Although the civil rights and environmental moveinents, pointing as they did to unfairness toward outsiders in the local land use regulation process, undoubtedly had soine role in reviving the idea of a general plan, it was the mternal problems in local administration that provoked the criticisin and analysis ultimately reflected in plan jurisprudence. Among these problems, the most prominent were the notoriously leaky variance process and the worrisome questions surrounding referenda on land use decisions. The next two Subsections trace the history of the issues involved in controlling variances and referenda.

\section{Variances and the Quasi-Judicialization of Land Use Decisions}

In the early SZEA model of land use control, the variance process allowed exceptions from general zoning regulations where, due to special circumstances, the owner of a particular property would suffer special hardship by the strict apphication of the general ordinance, and where relaxing the regulation would not be "contrary to the public interest."73 In such hardship cases, the possibility of getting a variance allayed charges that the general ordinance was an unconstitutional "taking" of property. ${ }^{74}$

Even in the early years of zoning, however, one of the leaders of

72. See supra notes $19-22$ and accompanying text.

73. SZEA, supra note $29, \S 7$.

74. 4 R. ANDERSON, supra note $10, \S 17.11$. See also Nectow v. City of Cambridge, 277 U.S. 183 (1928). 
the city planning movement complained that variance boards granted variances simply when they thought no harm would be done. ${ }^{75}$ During the mid-1950's and 1960's, academic studies of the variance process confirmed this pattern: Zoning adjustinent boards granted variances in a seemingly haphazard fashion, disregarding both the statutory standards of special hardship or umique circumstances and such procedural miceties as notice to interested parties, establishment of a record, and statements of findings. ${ }^{76}$

A chief complaimt about the variance proceeding was that it could eviscerate a zoning ordmance and any plan on whicl the ordinance was based. Easy variances made cities' plans the victims of importuning land developers. ${ }^{77}$ One Chicago study in the 1950's noted that the city's board of adjustment approved the vast majority of variance applications with very little attention to the views of the professional planners. ${ }^{78}$ Later studies in Philadelphia ${ }^{79}$ and Alameda County, Califorma ${ }^{80}$ came to the same conclusion. A Kentucky study remarked that one group of applicants-would-be gas station operators-viewed variances more or less as a matter of right. ${ }^{81}$ The only Band-Aid on the variance hemorrhage was the possibility that the neiglibors miglit complain: contested variances were granted considerably less often than uncontested ones. ${ }^{82}$ But to the critics, this fact only higlilighted the political and arbitrary character of the variance process and low it engendered disrespect for law. ${ }^{83}$

While soine cominentators attributed the variance flood to the ri-

75. E. Bassett, Zoning: The Laws, administration and Court Decisions During THE FIRST TwENTY YEARs 142 (2d ed. 1940). See also Anderson, The Board of Zoning AppealsVillain or Victim?, 13 SYRAcuse L. Rev. 353, 378 (1962).

76. Dukeminier \& Stapleton, The Zoning Board of Adjustment: A Case Study in Misrule, 50 KY. L.J. 273 (1962); Comment, Zoning Amendments and Variations, and Neighborhood Decline in Illinois, 48 Nw. U.L. REv. 470, 480 (1953); see also Goldston \& Scheuer, Zoning of Planned Residential Developments, 73 HARv. L. REv. 241, 252 (1959). For a discussion of the related problem of "special exceptions" granting discretionary permits to churches, see Note, Churches and Zoning, 70 HARV. L. REV. 1428, 1432-34 (1957).

77. Dukeminier \& Stapleton, supra note 76, at 337-39; Reps, Discretionary Powers of the Board of Zoning Appeals, 20 LAW \& CONTEMP. ProBs. 280, 281-82 (1955); Comment, supra note 76, at 476; see also Topanga Ass'n for a Scenic Community v. County of Los Angeles, 11 Cal. 3d 506, 518, 522 P.2d 12, 19, 113 Cal. Rptr. 836, 843 (1974); Comment, Judicial Control over Zoning Boards of Appeal: Suggestions for Reform, 12 U.C.L.A. L. REV. 937, 951 (1965).

78. Comment, supra note 76 , at 480 .

79. See Note, Zoning-Variances and Exceptions: The Philadelphia Experience, 103 U. PA. L. REv. 516, 541-42 (1955) (planners' views virtually ignored as factor in study of zoning variances).

80. Comment, Zoning: Variance Administration in Alameda County, 50 CALIF. L. REv. 101, 108 (1962).

81. Dukeminier \& Stapleton, supra note 76, at 298.

82. Id. at 328-29; Note, Administrative Discretion in Zoning, 82 HARv. L. REv. 668, 675 (1969) [heremafter cited as Note, Administrative Discretion]; Note, supra note 79, at 541-42.

83. Babcock, The Unhappy State of Zoning Administration in Illinois, 26 U. CHI. L. REv. 509, 
gidity of the general zoning ordinances, ${ }^{84}$ they also proposed a narrower solution to the variance problem: variance boards should be held to the procedures of "quasi-judicial" or "administrative" bodiesterms that were often used interchangeably ${ }^{85}$ The position had several arguinents in its favor. First, the SZEA required mimutes in variance proceedimgs and allowed decisions to be appealed to a court; ${ }^{86}$ this implied that a board's record should at least be sufficient for a court to review. ${ }^{87}$ Second, board nembers were usually appointed and had duties comparable to those of administrative officers-applying the statutory standards of hardship and umque circumstances to individual cases. ${ }^{88}$ Fimally, and perhaps most important, quasi-judicial procedures might counterbalance zoning boards' tendency to be, as one court delicately put it, "msufficiently insulated" from developers seeking variances. 89

There were, however, certain problems with this characterization of the variance board's duties. "Unnecessary hardship" and "special circumstances" scarcely seeined to be matters calling for special administrative expertise, ${ }^{90}$ and the criterion "not contrary to the public interest" seemed even less to be a standard applied quasi-judicially. Indeed, in the 1930's, courts in Illinois ${ }^{91}$ and Maryland ${ }^{92}$ had overturned general variance authorization as an overbroad delegation of legislative

538 (1959); Dukeminier \& Stapleton, supra note 76, at 274-75, 303; Comment, supra note 76, at 482-83.

84. See, e.g., Dukeminier \& Stapleton, supra note 76, at 350; see also Note, Administrative Discretion, supra note 82, at 680, 683. But see Comment, supra note 76, at 474.

85. Dukeminier \& Stapleton, supra note 76, at 349-50; Reps, supra note 77, at 294-96; see also Babcock, supra note 83, at 538-39. Cf. Bryden, supra note 10, at 316-17 (proposing abolition of use variances, leaving aggrieved owners to a judicial remedy in the ordinary courts). For a discussion of the interclangeable use of the designations "administrative" and "quasi-judicial," see E. BASSETr, supra note 75, at 131. Cf. Comment, supra note 77, at 940-41; Note, Administrative Discretion, supra note 82, at 684.

86. SZEA, supra note $29, \S 7$. This section required mmutes of proceedings, records of examinations, and records of votes, but did not require findings or conclusions. Reviewing courts were entitled to take additional evidence, suggesting de novo proceedings rather than review of a quasi-judicial proceeding by the variance board.

87. Krasnowiecki, supra note 29 , at 1040 . But see Dukeminier \& Stapleton, supra note 76 , at 322 (referring to the variance board decision as quasi-judicial); id. at 330-35 (arguimg that findings of fact and statements of reasons were less important for judicial review than for forcing local decisionmakers to develop reliable and impartial procedures). For a similar view, see Comment, supra note 77 , at $947,952-53$.

88. E. BASSETr, supra note 75, at 121-22; Comment, supra note 80, at 101; cf. Babcock, supra note 83 , at 512 .

89. Topanga Ass'n for a Scenic Community v. County of Los Angeles, 11 Cal. 3d 506, 518, 522 P.2d 12, 19, 113 Cal. Rptr. 836, 843 (1974). 946-47.

90. Note, Administrative Discretion, supra note 82 , at 672,675 ; Comment, supra note 77 , at

91. Welton v. Hamilton, 344 IIl. 82 , 176 N.E. 333 (1931).

92. Sugar v. North Baltimore Methodist Protestant Churcl, 164 Md. 487, 165 A. 703 (1933). 
power. ${ }^{93}$

The vagueness of the variance criteria, and the lay status of the variance boards ${ }^{94}$ suggest that these boards were less expert administrators than representative groups of concerned but fair-minded citizens, compromising and smoothing conflicts among neighbors. ${ }^{95}$ The boards' own activities certamly suggested that they saw their duties as being akin to a mediatimg forum for development requests and neighbors' protests. They attempted to take into account genuinely interested objections, they granted requests where no such objections appeared ${ }^{96}$ or where the grant accorded with other uses in the vicinity, ${ }^{97}$ and they often mollified objectors by making conditional grants. ${ }^{98}$ Their real flaw, on this "nnediation" view, was their frequent failure to notify and grant a hearing to potential objectors.

If this view of board-as-unediator had prevailed, we might have seen a very different jurisprudence of local land use matters. But it did not. By the 1960's the general wisdom held that in order both to preserve an overall zoning scheme and to protect the parties immediately interested, variances should be guided through procedures more rigorous than developer pressure as tempered by neighborhood uproar. Administrative law inodels suggested an analogy of the variance to quasijudicial procedures, and perhaps it is not surprising that the courts grasped the analogy, at least to the extent of requiring records and findings that related variance decisions to what were considered the applicable standards. ${ }^{99}$ If nothing else, such procedures gave the courts a stable point of departure in reviewing variance proceedings.

Meanwhile, in two celebrated articles in the mid-1950's, Charles Haar extended the variance criticism to the zoning ordinance itself, ar-

93. Babcock, supra note 83 , at 515-19.

94. Anderson, supra note 75 , at 358 ; Comment, supra note 77 , at 942.

95. Anderson, supra note 75 , at 358 . For one case taking a mediative view of boards of adjustment, see Burger King Corp. v. Amelkin, 70 A.D.2d 627, 416 N.Y.S.2d 528 (1979) (citing Lemir Realty Corp. v. Larkin, 11 N.Y.2d 20, 25, 181 N.E.2d 407, 409, 226 N.Y.S.2d 374, 377 (1962)). Bryden, supra note 10 , at 296 , noted the lay character of the boards, but thought this contrary to an eartier notion of variance boards as comprising experts. Id. at 291-92.

96. See supra note 82 .

97. Note, supra note 79, at 534, 542. For examples of this practice of zoning boards, see Morris v. City of Catlettsburg, 437 S.W.2d 753, 755 (Ky. 1969); Lindburg v. Zoning Bd. of Appeals, 8 Ill. 2d 254, 133 N.E.2d 266 (1956) (board's grant of variance overturned).

98. Babcock, supra note 83, at 536; see generally 3 R. ANDERSON, supra note 10, § 304.

99. See, e.g. , Lindburg v. Zoning Bd. of Appeals, 8 Ill. 2d 254, 133 N.E.2d 266 (1956); Morris v. City of Catlettsburg, 437 S.W.2d 753 (Ky. 1969); Zimck v. Zoning Bd. of Appeals, 345 Mass. 394, 187 N.E.2d 665 (1963); Harrington GIen, Inc. v. Municipal Bd. of Adjustment, 52 N.J. 22, 243 A.2d 233 (1968); R-N-R Assocs. v. Zoning Bd. of Review, 100 R.I. 7, 210 A.2d 653 (1965). See generally Comment, supra note 77, at 940-41. For an influential later case, see Topanga Ass'n for a Scenic Community v. County of Los Angeles, 11 Cal. 3d 506, 522 P.2d 12, 113 Cal. Rptr. 836 (1974). For an interesting comparison, see P. NoNET, ADMINISTRATIVE JuSTICE (1969) (tracing the "legalization" of the California Industrial Accident Commission). 
guing that unless bound to the standards of a preexisting plan, zoning ordinances too could be passed merely to grant special favors or to accommodate developers' pressures. ${ }^{100}$ Haar's articles were the first inajor critiques of the courts' treatment of the relationship between planning and zoning. Even though the SZEA required that land use controls be "im accordance with a comprehensive plan," Haar argued, the courts had vitiated that requirement by viewing it as satisfied if the zoning ordinance was citywide, or covered a variety of uses, or indeed was merely "well-considered." 101 Haar contended that the plan should be viewed as a "constitution," 102 and that zoning ordinances should be judged by their conformity with it.

Some courts began to find Haar's ideas useful im reviewing challenged zoning ordinances. The difference between variances and sinall zoning amendments had always been blurred in practice; locahities had long used the two techniques as inore or less interchangeable inethods to arrive at piecemeal changes. ${ }^{103}$ If variances required adherence to standards and findings, why should amendments be treated differently? Thus, as in the case of variances, plan conformity offered the courts a way to structure their review of these rezoning ordinances, particularly when the neighbors challenged the ordinance on vague public imterest grounds. ${ }^{104}$ From the point of view of the courts, plan conformity saved them from resting on their own unaided version of the "public interest," and instead channeled their review along procedural lines. ${ }^{105}$ Moreover, requiring the community to adhere to its own prior plan seemed to increase fairness to the neighbors, not only by protecting them against surprise, but also by giving them a starting poimt for their legal arguinents.

Later commentators, going beyond Haar's view of the plan as a

100. Haar, supra note 33, at 1174; Haar, The Master Plan: An Impermanent Constitution, 20 LAW \& Contemp. ProBs. 353, 365-66 (1955) [hereinafter cited as Haar, The Master Plan].

101. Haar, supra note 33, at 1170-73.

102. Haar, The Master Plan, supra note 100, at 375; see also Curtin \& Shirk, Land Use, Planning and Zoning, 9 URB. LAW. 724, 725-26 (1977).

103. E. BASSETT, supra note 75, at 144-46; Babcock, supra note 83, at 515-19; Comment, supra note 80 , at 104 n.18.

104. See Eves v. Zoning Bd. of Adjustment, 401 Pa. 211, 164 A.2d 7 (1960); Krasnowiecki, Planned Unit Development: A Challenge to Established Theory and Practice of Land Use Control, 114 U. PA. L. Rev. 47, 73-77 (1965) [hereinafter cited as Krasnowiecki, Planned Unit Development]. See also Krasnowiecki, supra note 29, at 1038 n.29. But see Kozesnik v. Township of Montgoinery, 24 N.J. 154, 165-66, 131 A.2d 1, 7 (1957) (citing Haar's work to hold that the phrase "in accordance with a general plan" did not require an independent plan-a strained use of Haar's articles, in view of his criticisin of that position).

105. See Eves v. Zoning Bd. of Adjustunent, 401 Pa. 211, 215-17, 164 A.2d 7, 11-12 (1960). As one observer, Jan Krasnowiecki, astutely remarked, casting the courts' decisions in terms of plan conformity allowed the courts to call on the planners' expertise. Krasnowiecki, Planned Unit Development, supra note 104, at 67. 
guide to legislation, easily took the next procedural step: If the plan was the standard for zoning, then individual rezoning ordinances were not legislative decisions but quasi-judicial apphications of the plan, and the decisioninakers should be held to quasi-judicial procedures. ${ }^{106}$ The basic argument these commentators made was that in rezoning individual parcels, city councils essentially acted as judges, measuring specific facts against the standards of the plan.

These commentators distinguished individual parcel rezonings from large-scale citywide rezonings on the basis of the familiar administrative law distinction between legislative and adjudicative subject matter: large-scale rezonings involved policy decisions balancing great multitudes of facts, and were thus appropriate for legislative treatınent, whereas small-scale rezonings involved particular parties and limited nunbers of facts, which should be measured against the preexisting general pohicies. ${ }^{107}$ Commentators also referred to political considerations suggestive of The Federalist No. 10 to support the distinction: general rezonings affected large numbers of citizens, who would let their councilmen know their views and therefore would protect theinselves through the ordinary political process; but in small-scale rezonings, the number of interested parties was limited, and those among them with contacts might have grossly disproportionate political infiuence. ${ }^{108}$ As in the variance context, there loomed behind the small-

106. In 1966, Richard Babcock took this view in his popular and influential critique of local land practice, The Zoning Game. R. BABCoCK, supra note 4, at 158. Two years later, the Anerican Law Institute (ALD, in its first tentative draft of a new Model Land Redevelopment Code, strongly suggested that local governing councils, like local variance boards, should be held to quasi-judicial proceedings in small-scale land decisions. MODEL LAND DEV. CODE \$\& 3-106, 8104, 8-202 (Tent. Draft No. 1, 1968). In 1971, Kentucky's highest court, interpreting a new state planning and zoning enabling statute, found that a local council acted in a quasi-judicial capacity in making an exception to the statutory requirements for plan conformity; explicitly referring to administrative law doctrine, the court held that the local council would have to hold a "trial type" hearing (as opposed to an "argument" hearing) to determine whether the statutory criteria for rehef had been inet. City of Louisville v. McDonald, 470 S.W.2d 173, 177-78 (Ky. 1971). The next year, an Ohio State Law Journal Conıment, perhaps unimportant in itself except for its later citation in Fasano and other plan jurisprudence cases, mamtained this same position. See Coininent, Zoning Amendments-the Product of Judicial or Quasi-Judicial Action, 33 OH1O ST. L.J. 130 (1972). For cases citing the Conument, see Fasano, 264 Or. at 581, 588, 507 P.2d at 26-27, 30; Snyder v. City of Lakewood, 189 Colo. 421, 426, 542 P.2d 371, 376 (1975); Kropf v. City of Sterling Heights, 391 Mich. 139, 169 n.5, 215 N.W.2d 179, 192 n.5 (1974) (Levin, J., concurring). See also Ed Zaagman, Inc. v. City of Kentwood, 406 Mich. 137, 200 n.31, 277 N.W.2d 475, 498 n.31 (1979) (Levin, J., concurring in part and dissenting in part).

107. Comment, supra note 106, at 137; see also Fleming v. City of Tacoma, 81 Wash. $2 d 292$, 299, 502 P.2d 327, 331 (1972); Booth, A Realistic Reexamination of Rezoning Procedure: The Complementary Requirements of Due Process and Judicial Review, 10 GA. L. REv. 753, 776, 780 (1976).

108. Comment, supra note 106, at 132. See also Freilich \& Larson, Conficts of Interest: A Model Statutory Proposal for the Regulation of Municipal Transactions, 38 UMKC L. Rev. 373, 390-98 (1970). Later plan jurisprudence cases continued to stress the possibihity that development interests might have disproportionate influence. See, e.g., Topanga Ass'n for a Scenic Community 
scale rezoning the specter of the influential developer, from whom the neighbors needed refuge im a quasi-judicial forum whose decisions met the standards of the duly considered plan.

Thus by the early 1970 's, a perception that localities were yielding too easily to haphazard development pressures had brought courts and commentators well along toward plan jurisprudence. Some courts not only required that local land use decisions conform to an independent plan, but also recharacterized at least some of the those decisions as quasi-judicial, not legislative. Apparently, they thought that local legislatures were no stronger than variance boards in standing up to the factional influence of developinent pressure. To protect a semblance of due consideration, as well as the neighbors' interests, they began to hold the local decisionmakers to another procedural model-i.e., the quasi-judicial application of a preexisting plan.

\section{Referenda and the Problem of Controlling Majoritarian Rule}

In the variance context, the developers represented a "factional" influence of special economic imterests. But the voters themselves sometimes seeined to represent another type of faction-that of popular prejudice or caprice. Indeed, voter decisions rather than developer influence generated a second set of worries about local land use administration: Could zoning changes be made by referenda or even more troublesome, by mitiative? Could the voters reject the city council's zoning amendments, or, to up the ante, could they come up with zoning amendments of their own? And if they could do either, what happened to the idea of zoning according to a general plan?

Questions like these came up when voters threatened to disapprove commercial developments or apartment projects approved by planning commissions and city councils but challenged by referenda. In the state courts, these questions frequently revolved around the issue of whether individual zoning ainendments were legislative acts settimg general policy, or administrative acts merely executing existing legislative policy; if the former, then rezonings were subject to voter approval; if the latter, then only the city council, as executor of existimg policy, could inake the decisions. ${ }^{109}$

v. County of Los Angeles, 11 Cal. 3d 506, 518, 522 P.2d 12, 19, 113 Cal. Rptr. 836, 843 (1974); South of Sunnyside Neighborhood League v. Board of Comm'rs, 280 Or. 3, 14, 569 P.2d 1063, 1073 (1977).

109. For cases holding that zoning amendments are administrative and thus not subject to referendum or initiative, see, for example, West v. City of Portage, 392 Mich. 458, 471-72, 221 N.W.2d 303, 309-10 (1974); Kelley v. John, 162 Neb. 319, 323-24, 75 N.W.2d 713, 715-16 (1956); Forman v. Eagle Thrifty Drugs \& Mkts., Inc., 89 Nev. 533, 537-38, 516 P.2d 1234, 1236-37 (1973). See also City of Scottsdale v. Superior Court, 103 Ariz. 204, 207-08, 439 P.2d 290, 293-94 (1968) (en banc) (statutory approval process required); Olson v. Town of Avon, 143 Conn. 448, 451-54, 
These problems agam focused attention on the general plan as the existimg pohicy to be carried out administratively. As several courts noted, amendments by popular vote could destroy piecemeal the comprehensive and harmonious scheme that zoning was designed to promote. ${ }^{110}$ A second issue was the procedural suitability of a popular vote on an individual's property, where popular emotions were unrestramed even by ordinary city council processes. The planning con1mission reports, the pubhic hearmgs, and the collegial discussion and decisioninaking were all dispensed with. ${ }^{11}$

State courts had grappled with these issues for several years when the Umited States Supreme Court made two major constitutional decisions upholdimg local referenda. Both concerned voter objections to multifamily housimg projects. First, in its 1971 decision in James $\nu$. Valtierra, ${ }^{12}$ the Court upheld California's requirement that subsidized low-income housmg projects be approved by local referenda. Then, in its 1976 decision in City of Eastlake v. Forest City Enterprises, Inc. ${ }^{113}$ the Court upheld a local charter amendment adopted by referendum after the city council rezoned to permit a multifamily housmg project; the charter amendment required that any future rezoning pass a fiftyfive percent referendum majority. The Ohio Supreme Court had held that this referendum procedure violated due process requirements, smce a referendum made the rezoning decision "dependent upon the potentially arbitrary and unreasonable whims of the votnig pubhic."114 But the United States Supreme Court reversed, notmg that the Ohio court had ruled that rezonings were legislative rather than administrative acts. ${ }^{115}$ The local council merely acted for the people in such legis-

123 A.2d 279, $281-82$ (1956) (town meeting decision improper); State ex rel. Powers v. Donohue, 368 S.W.2d 432 (Mo. 1963) (en banc). But see San Diego Bldg. Contractors Ass'n v. City Council, 13 Cal. 3d 205, 212-18, 529 P.2d 570, 574-78, 118 Cal. Rptr. 146, 150-54 (1974) (zoning ordinance is legislative; notice not required in imitiative context), appeal dismissed, 427 U.S. 901 (1976); Denney v. City of Duluth, 295 Minn. 22, 28, 202 N.W.2d 892, 895-96 (1972) (zoning ainendinent is legislative, not administrative).

110. West v. City of Portage, 392 Mich. 458, 466-69, 221 N.W.2d 303, 307-08 (1974); Kelley v. John, 162 Neb. 319, 321-23, 75 N.W.2d 713, 714-15 (1956); Forman v. Eagle Thrifty Drugs \& Mkts., Inc., 89 Nev. 533, 537-38, 516 P.2d 1234, 1236-37 (1973); Bird v. Sorenson, 16 Utah 2d 1, 2, 394 P.2d 808, 808 (1964); see also Elliott v. City of Clawson, 21 Mich. App. 363, 376, 175 N.W.2d 821, 828 (1970); Township of Sparta v. Spillane, 125 N.J. Super. 519, 525, 312 A.2d 154, 157 (1973); Dewey v. Doxey-Layton Realty Co., 3 Utah 2d 1, 6-7, 277 P.2d 805, 808-09 (1954); Note, Limitations on Initiative and Referendum, 3 STAN. L. REv. 497, 502-04 (1951).

111. See supra note 110 and authorities cited therein; City of Scottsdale v. Superior Court, 103 Ariz. 204, 207-08, 439 P.2d 290, 293-94 (1968); Hancock v. Rouse, 437 S.W.2d 1 (Tex. Civ. App. 1969).

112. 402 U.S. 137 (1971).

113. 426 U.S. 668 (1976).

114. Forest City Enters., Inc. v. City of Eastlake, 41 Ohio St. 2d 187, 195, 324 N.E.2d 740, 746 (1975).

115. 426 U.S. at $673-74$. 
lative acts, the Court reasoned, and the sovereign people could constitutionally reserve to itself a type of decision that otherwise would have been made by the local council in its legislative capacity. ${ }^{116}$

It might seem that Eastlake leaves to the states the characterization of local land changes. So viewed, the case might well allow a state to characterize piecemeal changes as neither legislative nor judicial but as something else - a point to which I shall return. ${ }^{117}$ But the Court's discussion of the "legislative" rubric, together with Justice Stevens' dissenting citation of Fasano and its "judicial" characterization of piecemeal changes, ${ }^{118}$ directed the ensuing academic and legal discussion into conventional separation-of-powers channels, where the only choices among processes are legislative and judicial (or an administrative variant of the latter).

Certainly Valtierra and Eastlake did not settle the controversy over zoning amendments by popular vote; on the contrary, the decisions only fueled the debate. Academic commentators criticized Eastlake's "reserved powers" argument, and commented on the procedural due process problems entailed in leaving complex decisions (particularly on such subjects as public housing) to an overheated populace; no one could reahistically expect that the people at large-as distinguished from their city councils-would hold hearings, sift through reports, debate issues, or record their views on the relevant evidence and appropriate conclusions. ${ }^{119}$ Eastlake critics also pointed out that a decision by referendum was especially unlikely to be guided or restrained by the local general plan. ${ }^{120}$

These considerations led soine state courts, even after Eastlake, to invalidate referenda on land use decisions; they saw the issues as ad-

116. Id. at 677 .

117. See infra Part III.

118. 426 U.S. at 684.

119. Hogue, Eastlake and Arlington Heights: New Hurdles in Regulating Urban Land Use?, 28 CASE W. Res. L. Rev. 41, 53-66 (1977); Kahn, In Accordance with a Constitutional Plan: Procedural Due Process and Zoning Decisions, 6 Hastings Const. L.Q. 1011, 1018-20, 1045-48 (1979); see, e.g., Sager, Insular Majorities Unabated: Warth v. Seldin and City of Eastlake v. Forest City Enterprises, Inc., 91 HARv. L. Rev. 1373, 1402-25 (1978); Wolfstone, The Case for a Procedural Due Process Limitation on the Zoning Referendum: City of Eastlake Revisited, 7 EcoLOGY L.Q. 51, 78-84 (1978); Note, The Proper Use of Referenda in Zoning, 29 STAN. L. Rev. 819, 832-37 (1977) [hereinafter cited as Note, Proper Use of Referenda]. Sce also San Diego Bldg. Contractors Ass'n v. City Council, 13 Cal. 3d 205, 22I-24, 529 P.2d 570, 580-82, 118 Cal. Rptr. 146, 156-58 (1974) (Burke, J., dissenting); Glenn, State Law Limitations on the Use of Initiatives and Referenda in Connection with Zoning Amendments, 51 S. CAL. L. REv. 265, 286, 304-05 (1978); Note, Arnel Developmeut Co. v. City of Costa Mesa: Rezoning by Initiative and Landowners' Due Process Rights, 70 CaLlF. L. Rev. 1107, 1125-29 (1982); Comment, Zoning by Initiative in California: A Critical Analysis, 12 Loy. L.A.L. Rev. 903, 910-15 (1979). But see Comment, The Initiative and Referendum's Use in Zoning, 64 CALIF. L. Rev. 74 (1976) (defending use of referendum in land use decisions).

120. Hogue, supra note 119, at 61-66; Note, Proper Use of Referenda, supra note 119, at 843. 
ministrative or even judicial rather than legislative. ${ }^{121}$ Whichever characterization they used, ${ }^{122}$ these state courts held that nonlegislative decisions were to be made by fixed processes according to the standards already set out in the plan.

But if the land use changes were not legislative for purposes of a referendum, then why should they be legislative when made by a city council? The council meinbers, after all, were bound to be swayed by the interests of their constituents. ${ }^{123}$ This anomaly bolstered the step taken in Fasano: the treatment of all small-scale land use decisions not as legislative acts but as quasi-judicial decisions, so that even elected representatives must follow courtlike procedures in applying the overall policies of the plan to individual properties. ${ }^{124}$

Indeed, the referendum cases pointedly illustrated why individual land changes might require some check on arbitrariness, regardless of whether these changes were made by variance boards or elected councils or the citizens themselves. Perhaps the most miportant feature of the referendum discussion was that it justified The Federalist's mistrust of the militant local community as a type of faction. Referenda on housing projects were particularly troubling, but even the shopping center cases showed how an aroused local populace could trample the legitimate property expectations of an individual owner or developer. ${ }^{125}$ To check unfairness to the individual owner, and to halt the seeming irrationality of pieceineal changes, soine courts turned to procedures involving soine version of consistency with a larger plan. The content of any given plan seemed less important in these discussions than the need to restrain local action by some legal standard set out in advance, which the courts could call upon as a test of reasonableness.

Thus at least two strands of zoning decisions and coinmentaries

121. See, e.g., Wright v. City of Lakewood, 43 Colo. App. 480, 608 P.2d 361 (1979), rev'd, 638 P.2d 297, 304 (Colo. 1981); City of West Haven v. Impact, 174 Conn. 160, 164-65, 384 A.2d 353, 355 (1978); Leonard v. City of Bothell, 87 Wash. 2d 847, 851-53, 557 P.2d 1306, 1309-10 (1976) (en banc). But see Amel Dev. Co. v. City of Costa Mesa, 28 Cal. 3d 511, 521, 620 P.2d 565, 571, 169 Cal. Rptr. 904, 910 (1980).

122. It is not always clear whether the rezoning is being cast as an "administrative" or a "quasi-judicial" act. See, e.g., Wright v. City of Lakewood, 43 Colo. App. at 481, 608 P.2d at 362. Wolfstone collapses these "judicial," "quasi-judicial," and "admimistrative" designations into the single category "nonlegislative." Wolfstone, supra note 119, at 87. All require some degree of due process. The author maintains that the degree of process should depend on the interests involved. Perhaps this blurring is not surprising. Vile notes the historic blurring of executive and judicial functions in the doctrine of the separation of powers. M. VILE, CoNSTITUTIONALISM AND THE Separation of Powers 88-90, 137-38, 327 (1967).

123. See Udell v. Haas, 21 N.Y.2d 463, 469, 235 N.E.2d 897, 901, 288 N.Y.S.2d 888, 894 (1968).

124. Developments in the Law-Zoning, 91 HARv. L. Rev. 1427, 1502-49 (1978); see also D. LAUber, The Hearing EXAMINer in ZoNing ADMinistration 8-9, 16 (1975).

125. See, e.g., Note, Proper Use of Referenda, supra note 119, at 847-48. 
urged plan jurisprudence as a control on local land use decisions. The variance and referenda cases, turning as they did on developer demands at the one extreme and popular pressures at the other, illustrated the potentially "factional" nature of piecemeal changes, as well as their particular vulnerability to partial judgments, haste, and lack of consideration or fairness.

The courts' and commentators' analyses of these two problems suggested quasi-judicial application of a general plan as a solution. Like the discretion-structuring model from administrative law, this solution seemed to safeguard carefulness and fairness where the ordimary legislative process might fail. In addition, it was ideal for judical review. It prescribed readymade standards in the forn of a local plan, thus relieving the courts from having to imvent substantive public interest criteria for themselves. At the same time, it enabled thein to prescribe a familiar and regularized adjudicative procedural forn for the local decisionmakers. Thus, plan jurisprudence clarified for the courts both the substance and the procedure for review of local piecenneal changes, and did so in such a way as to permit considerable judicial control over all these troublesome "deals."

Although plan jurisprudence offers administrative law principles as a substitute for the safeguards in larger legislative bodies, it has soine difficulties. The following Part deals with three of them: first, the logical and practical problems in fitting local land decisions into the mold of quasi-judicial administrative determinations; second, the equally serious problems with the courts' distinctions between legislative and quasi-judicial (or administrative) ${ }^{126}$ land use regulations; third and most fundamentally, the reasons to doubt that a fixed land use plan, made im advance of actual control decisions, can or should be the standard by which those decisions are tested.

II

Problems in Plan Jurisprudence

\section{A. The Treatment of Local Governmental Decisions as Quasi-Judicial}

In characterizing local governments' land use changes as quasijudicial administrative decisions, the courts must make a prior assumption, namely that local governing bodies can be likened to administrative agencies of the state government. ${ }^{127}$ According to plan jurisprudence, the courts view local governing bodies as if they, like administrative agencies, could move back and forth between the tradi-

126. See supra note 122 .

127. See supra note 51 and accompanying text. 
tional legislative and judicial functions, wearing a judicial hat when, for a particular task, the "legislative" rubric cannot ensure fairness and due consideration. This raises a question: Are local bodies equipped to make these switches so that, when they supposedly act judicially, fairness and due consideration are ensured?

The judicial or quasi-judicial function has its own criteria for fairness and due consideration, notably the presence of preexistimg standards and procedural rules that channel discussion and decision of each individual case toward those standards. ${ }^{128}$ But The Federalist's examination of judicial due consideration and fairness had another element as well: secure tenure of office, in order to promote judicial steadiness, impartiality, and insulation from irrelevant pressures. ${ }^{129}$ Administrative agencies, and, even more, elective local governing offcials, lack this additional legitimizing aspect of the federal judicial branch.

In the traditional doctrine of administrative law, the chief substitute for the guarantee of institutional competence provided by life tenure is technical expertise; mastery of the subject matter ensures that the agency will come to the correct conclusion. ${ }^{130}$ Even in inany adininistrative agencies, technical expertise has become more debatable of late as an assurance of sound decisions, though no very good alternativc has been identified. ${ }^{131}$ But in local governments' land changes, technical expertise is no assurance at all, because local governinents simply do not have it.

Administrative agencies traditionally exercise their discretionary powers within a defined subject matter-consumer product safety, for example, or environmental protection, or a given forin of transporation. ${ }^{132}$ Local governing bodies, on the other hand, exercise general powers of governinent, ${ }^{133}$ limited by geographic area rather than by subject matter. Land use issues nnight to soine degree be regarded as specialized matters, but on closer examination their specialized quality

128. See, e.g., Goldberg v. Kelly, 397 U.S. 254, 271 (1970) (due process hearing requires decision based on legal rules). See also The Federalist No. 78, at 529 (A. Hamilton) (J. Cooke ed. 1961).

129. The Federalist No. 78, at 522-24, 527-29 (A. Hamilton) (J. Cooke ed. 1961). See also S. BREYER \& R. STEWART, supra note 57, at 103-04; Freedman, Crisis and Legitimacy in the Admin. istrative Process, 27 STAN. L. Rev. 1041 (1975).

130. See, e.g., NLRB v. Gissel Packing Co., 395 U.S. 575, 612 n.32 (1969); ICC v. Chicago, R.I. \& P. Ry., 218 U.S. 88, 102 (1910); J. LANDIS, The Administrative Process 23-24, 30-31 (1938); Sabatier, Social Movements and Regulatory Agencies: Toward a More Adequate-and Less Pessimistic-Theory of "Clientele Capture," 6 PoL'Y SCI. 301, 302 (1975).

131. S. BREYER \& R. STEWART, supra note 57, at 104; Freedman, supra note 129, at 1058-60; Stewart, supra note 16 , at 1682-85.

132. J. LAND1S, supra note 130 , at 25-26.

133. 2 E. MCQUILLAN, supra note $55, \S \S 4.08,4.80$. 
evaporates. It is true that local governments are advised by planning commissions, but the commissioners are normally ordinary citizens with no special expertise. ${ }^{134}$ Planning commission advisory staffs are professionals, but even professional planners have come to see their tasks as more political than technical. ${ }^{135}$ The local governing bodies who pass zoning ordinances and amendments have more and more come to use land use controls as a general ineans of governing. ${ }^{136}$ If they have any "expertise" in land as such, it derives less from professional or technical education or information than from slieer familarity with a locality taken as a whole, in all its complexity. ${ }^{137}$ This expertise is of a quite different order from that which substitutes for life tenure, and the difference has bedeviled the quasi-judicialization of local land use decisions.

Indeed, any notion of adjudicative impartiality is threatened by the kind of expertise local decisionmakers do have: namely, political expertise. Can local decisionmakers really be expected to be imipartial in their quasi-judicial capacity when they are not in their other capacities? A number of recent cases have focused on council ineinbers' ex parte contacts in quasi-judicial land decisions, and have raised some particularly knotty problems. For example, inay council members, at the same time that they act quasi-judicially on a rezoning application, correspond with the applicant about a possible city purchase of some of the applicant's adjoining land? ${ }^{138}$ May they informally solicit the views of their neighbors and the local inerchants before decidimg to permit a proposed shopping center? ${ }^{139}$ Should they be disqualified because they have previously stated their opposition to a proposed shopping center? 140

134. 4 R. ANDERSON, supra note 10, § 21.20; Tarlock, Kentucky Planning and Land Use Control Enabling Legislation: An Analysis of the 1966 Revision of K.R.S. Chapter 100, 56 KY. L.J. 556, $586-87$ (1968).

135. A. Catanese \& W. Farmer, Personality, Politics and Planning 180-91 (1978); see $i d$. at 193 (advocacy planning tends to favor groups considered to be underrepresented politically).

136. See, e.g., Young v. American Mini Theatres, Inc., 427 U.S. 50 (1976) (upholding zoning to restrict location of adult movies and bookstores); Village of Belle Terre v. Boraas, 416 U.S. 1, 910 (1974) (upholding zoning to exclude nonfamily multiple person households); $c f$. Framingham Clinic, lnc. v. Board of Selectmen, 373 Mass. 279, 284-87, 367 N.E.2d 606, 610-11 (1977) (overturning zoning that prohibits abortion clinics).

137. See infra note 142 and accompanying text.

138. Neuberger v. City of Portland, 288 Or. 585, 589-90, 607 P.2d 722, 725-26 (1980) (yes, where the contact did not suggest bias on the zoning change).

139. Tierney v. Duris, 21 Or. App. 613, 627-29, 536 P.2d 435, $442-43$ (1975) (yes, where the questioned persous were relatively disinterested, the questious concerned the merits of the permit, and the contacts were inade a part of the record).

140. City of Fairfield v. Superior Court, 14 Cal. 3d 768, 780-81, 537 P.2d 375, 382-83, 122 Cal. Rptr. 543, 550-51 (1975) (no, because council inembers are obligated to talk to constituents and express their views). See also Turf Valley Assoc. v. Zoning Bd., 262 Md. 632, 644, 278 A.2d 574, 580-81 (1971) (campaign promises do not disqualify council members absent showing of conflict 
In each of these cases the courts have refused to disturb the council members' actions, despite the supposedly quasi-judicial nature of the decision. As the California Supreme Court observed in the case that furnished the last example, ${ }^{141}$ a councilman "has not only a right but an obhigation to discuss issues of vital concern with his constituents and to state his views on matters of public importance." The court went on to quote an earlier case on the role of the council member:

A city councilman is elected usually because of his acquaintanceship and popularity. He may not be instructed on many of the technical matters to which he is called upon to pass judgment. He is frequently an extrovert, who circulates widely in the community and talks with busmessmen and voters about all sorts of questions that may come before the council. ${ }^{142}$

These problems with ex parte contacts, and with the closely related appearance-of-fairness doctrine ${ }^{143}$ point to a fundamental contradiction in the attempt to use administrative law analogies to discipline local land use decisions. A local council is hard put to take on even that most fundamental attribute of a judicial body, impartiality. ${ }^{144}$ The situation only worsens if a decision is viewed as quasi-judicial under administrative doctrine, where judicial attributes supposedly flow from expertise. If a council's administrative legitimacy rests on "expert" knowledge of the local area, that expertise comes from contact with the locality. A large part of a council member's activities rightly consists of talking to constituents and interested parties about local conditionsbut that contact, in turn, threatens impartiality. The result is that insisting upon quasi-judicialization, which includes impartiality, undermines the very justification for treating local governments as expert administrative agencies in the first place. Thus the hoary hornbook justification for administrative exercise of judicial powers-agency expertise over the subject inatter-argues against, rather than for, the quasi-judicial treatment of local land use decisions.

of interest). But see Marmah, Inc. v. Town of Greenwich, 176 Conn. 116, 121-23, 405 A.2d 63, 65 (1978) (procedures appearing to favor project opponents disqualified decision as biased).

141. City of Fairfield v. Superior Court, 14 Cal. 3d 768, 780, 537 P.2d 375, 382, 122 Cal. Rptr. 543,550 (1975). The case involved approval of a planned unit development, a decision that California courts treat as quasi-judicial. See also Woodland Hills Residents Ass'n, Inc. v. City Council, 26 Cal. 3d 938, 947, 609 P.2d 1029, 1033, 164 Cal. Rptr. 255, 260 (1980) (cainpaign contributions do not give rise to appearance of unfairness).

142. City of Fairfield v. Superior Court, 14 Cal. 3d 768, 780, 537 P.2d 375, 382-83, 122 Cal. Rptr. 543, 550-51 (1975). See also City of Beechwood Village v. Council of Saint Matthews, 574 S.W.2d 322, 324 (Ky. Ct. App. 1978) (presuming council meinbers' personal knowledge of facts).

143. See Fleming v. City of Tacoma, 81 Wash. 2d 292, 295-98, 502 P.2d 327, 329-30 (1972).

144. See Friendly, “Some Kind of Hearing", 123 U. PA. L. REv. 1267, 1279 (1975); cf. Verkuil, A Study of Informal Adjudication Procedures, 43 U. CHI. L. REv. 739, 787-89 (1976). 


\section{B. Finding the Line Between Legislative and Quasi-judicial Decisions}

Even supposing that local governments can make decisions as judges or administrators, the quasi-judicial treatment of local land use decisions faces another problem. By what criteria is a land use control decision quasi-judicial rather than legislative? Most of the case law and literature in plan jurisprudence has attempted to distinguish piecemeal changes from others by some index of the scope of the decision. But exactly when, and by what measure, does the decision become sufficiently broad to become legislative rather than adjudicative? And does any criterion of scope really make sense, im light of the purposes of treating these decisions as adjudicative?

In trying to define the scope of a decision sufficiently limited to merit quasi-judicial treatment, courts and commentators have suggested at least two measurements: the size of the lot or area involved in the decision, and the numbers of persons affected by the decision. ${ }^{145}$ Traditional administrative law doctrine might suggest that, by eitler of these criteria, small-scale decisions are appropriate for quasi-judicial treatment. Both a large area and a large number of parties might raise issues of general pohicy, whereas a smaller area, or a smaller number of parties, would be more likely to raise the mdividualized and specific facts appropriate for judicial treatment. ${ }^{146}$ But the two measures of scope do not appear to have equal weight. Commentators and at least some cases pay more attention to numbers of people than to lot size for political reasons that rest on considerations drawn from The Federalist No. 10: the more numerous the affected populace, the greater the interested parties' ability to protect themselves through the ordinary give-

145. See, e.g., Kropf v. City of Sterling Heights, 391 Mich. 139, 166 \& n.3, 215 N.W.2d 179, $191 \&$ n.3 (1974) (Levin, J., concurring); West v. City of Portage, 392 Mich. 458, 469, 221 N.W.2d 303, 304 (1974); Coon, The Initial Characterization of Land Use Issues, 6 EnvTL. L. 121, 126 (1975); Freilich, supra note 17, at vii, ix; Kahn, supra note 119, at 1032 (also suggesting party favoring change as criterion, e.g., private proposal may be quasi-judicial; category may be collapsible with criterion of numbers of persons affected). See also Developments in the Law-Zoning, supra note 124 , at $1510-13$.

146. Economic thinking might also suggest either criterion. In a sufficiently large area, the developer is more likely to "internalize externalities," and, except at the border, any regulatory issues are those of general development policy. See, e.g., Rodgers v. Village of Tarrytown, 302 N.Y. 115, 121-24, 96 N.E.2d 731, 734-35 (1951). In a smaller lot development, on the other hand, the predominating problems concern the external effects on the neighbors and call for a quasijudicial process to measure the respective owners' rights agamst some standard (i.e., the plan). $C f$. Ellickson, supra note 16, at 772-74 (favoring a judicial or quasi-judicial resolution of land use disputes between neighbors through "nuisance boards," but with standards drawn from community definitions of "neighborly" behavior).

As to numbers of interested persons, large numbers would be unable to transact to settle their rights by contract, suggesting a need for legislative intervention; but when only a few parties are involved, public intervention is required only to clarify their respective rights so that they can bargain thcreafter, suggesting a quasi-judicial application of standards. 
and-take of the legislative process, and the less the danger of unequal influence. ${ }^{147}$

Lot size has little bearing on the argument of The Federalist. Some commentators have noted that though a lot may be very large and may constitute a significant portion of a town's total land, the single owner's or developer's property interests might well collapse under the weight of a hostile majority of the citizens or representatives. ${ }^{148}$

A less-noted point, however, is that a numbers-of-people criterion might have equally little bearing in a local setting, where, at their greatest, total numbers must be relatively small on any issue. The argument of The Federalist is inapposite, for a local government is not always coinparable to an "extended republic" where the legislature is a foruin for many different issues, where different interests must trade off against each other in shifting coalitions, and where the entire process requires a sufficient pause and period of arguinent to take into account a inore general public interest. ${ }^{149}$ The local forum is necessarily a unuch smaller unit in which a single issue can split the entire jurisdiction, and in which a minority interest group may have no leverage as part of any coalition, or even time to asseinble arguments directed to a larger view of the cominunity welfare. Here, a quickly-assembled majority for, let us say, residential zoning and a short "ainortization" of existing uses may totally defeat owners of gas stations ${ }^{150}$ or grocery stores ${ }^{151}$-without the threat of the losers' political retahiation later. This can be true no inatter how niany losers there are. In fact, coininentators have pointed out that even broad and general plannimg ordinances have favored certain groups over others. ${ }^{152}$ Indeed, this is part of the arguinent for deregulation: that some interests can permanently capture and exploit local land use regulation at others' expense. ${ }^{153}$

147. See, e.g., Neuberger v. City of Portland, 288 Or. 155, 161, 603 P.2d 771, 775 (1979); Fleming v. City of Tacoma, 81 Wash. 2d 292, 294, 502 P.2d 327, 331 (1972); see also McKinstry v. Wells, 548 S.W.2d 169, 175 (Ky. App. 1977) (100 acre parcel rezoning is quasi-judicial). For commentary, see Coon, supra note 145, at 130-31; Glenn, supra note 119, at 303-06; Kahn, supra note 119 , at 1032-33.

148. Coon, supra note 145 , at 128-29.

149. See supra notes $63-68$ and accompanying text.

150. Standard Oil Co. v. City of Tallahassee, 183 F.2d 410, 413 (5th Cir.), cert. denied, 340 U.S. 892 (1950) (eight-month amortization period for nonconforming gas station upheld).

151. State ex rel. Dema Realty Co. v. McDonald, 168 La. 172, 178-79, 121 So. 613, 616, cert. denied, 280 U.S. 556 (1929). For a general discussion of amortization, see Graham, Legislative Techniques for the Amortization of the Nonconforming Use: A Suggested Formula, 12 WAYNE L. REv. 435, 440-46 (1966); Note, A Suggested Means of Determining the Proper Amortization Period for Nonconforming Structures, 27 STAN. L. REV. 1325 (1975).

152. See, e.g., H. Gans, People and Plans 62-65 (1968); see also R. Babcock, supra note 4, at $122-23$ (plan may be as arbitrary as zone); $f f$. A. Altschuler, THe City PlanNing Process $399-405$ (1965) (planners lack moral focus in the absence of professional standards).

153. Ellickson, supra note 4, at 404-10; Ellickson, supra note 15, at 1206-09; Kmiec, Deregulation, supra note 15 , at $41-42$. 
At least in the local context, then, the regulatory process may be a device for one group to dominate another and to bend decisions to its benefit. If this is true, then even when large numbers of persons are affected by a decision, they will be unprotected by the coalition-building safeguard. It follows that the number of persons affected will not be an accurate measure: If possible harm to minorities is the touclistone for the quasi-judicial characterization, then every local land use decision, even a citywide ordinance, is a candidate. ${ }^{154}$ At the local level, even the general ordinance inay oppress minority interests, and no decision deserves the loose standard of review implied by the "legislative" designation.

That is not all: the very notion of the plan-as-standard also militates for universal quasi-judicialization. If the plan is taken seriously, then all land use regulations, no matter how general in scope, should be quasi-judicial, because they all involve application of the plan's preestablished standards. If the plan lias already set the policy standards to be applied in approving the new zoning ordinance, or the new planned unit developinent, or the new subdivision approval, inust not all these regulatory decisions be viewed as adjudicative rather than legislative? Insofar as the plan is intended to discipline local decisionmaking, its logical outcoine is to make the nature of all land use regulatory decisions adjudicative.

In short, trying to draw a primcipled distimction between the judicial decisions and all others is impossible, given the criteria plan jurisprudence provides. But more important, the idea of a plan itself is equally problenatic, as the next Section will slow.

\section{Is the Plan Really a Standard?}

Plan jurisprudence's quasi-judicialization of land controls requires the application of a standard, which is normally the local master plan. Plan jurisprudence is significantly silent about the appropriate content of any master plan, ${ }^{155}$ perhaps because no general guidelines for content could possibly bear the weight that plan jurisprudence would put on thein. On several grounds a master plan cannot be the standard by which to measure individual land use regulatory decisions. Among these are (1) modern planning doctrine, and (2) actual local practice.

154. See Hurst v. City of Burlingame, 207 Cal. 134, 141, 277 P. 308, 311 (1929) (treating general zoning ordinance as quasi-judicial), overruled by Associated Home Builders of the Greater Eastbay, Inc. v. City of Livermore, 18 Cal. 3d 582, 596, 557 P.2d 473, 480, 135 Cal. Rptr. 41, 48 (1976) (en banc).

155. See, e.g., Green v. Hayward, 275 Or. 693, 698-700, 552 P.2d 815, 818-19 (1976) (court will not prescribe plan format where legislature has not done so). For a discussion of "plans" that are little more than undigested masses of data, see Tarlock, supra note 134, at 591-92. 


\section{Modern Planning Doctrine}

The previous Section suggested that a general plan may unfairly favor some groups at the expense of others. ${ }^{156}$ In Dan Tarlock's recent version of that argument, he points out that even if we require regulations to conform to a plan, we beg the question of the legitimacy of the plan itself ${ }^{157}$ for even plan consistency requirements leave the setting of goals to the same local governments whose other land use decisions are suspect.

The traditional answer to this objection is that the plan is adopted under different circumstances from the ordinary land use decision. Unlike a simple rezoning, the plan is created in an atmosphere of calm and deliberation, where expert opinions can be weighed and considered. ${ }^{158}$ Thus, the argument runs, the plan can be adequately considered precisely because the master plan precedes particular projects, with all their proponents and objectors and arguments. At the same time, the plan provides security and fair treatment to the citizenry by imposing consistent and inipartial results later, in actual land decisions. ${ }^{159}$ In the moments of popular excitement or developer enticement, the plan disciplines a wayward local government and prevents it from bargaining away its own well-considered views or its citizens' security. At best the plan should assure fairness and due consideration, without depending on the coalition-building nodel of the "extended republic."

This traditional answer may not be satisfactory. It is not at all clear that local governments-or indeed any governing bodies-operate very effectively in the cool circumstances envisioned by traditional planning theory. It is the legislative proposal itself that sets off a clash of interests in a legislative body, just as it is the actual case that focuses the attention of a court. ${ }^{160}$ Decision theorists have argued that concrete

156. See supra text accompanying notes 152-54.

157. Tarlock, supra note 5 , at $84,99-101$.

158. See, e.g., Udell v. Haas, 21 N.Y.2d 463, 470, 235 N.E.2d 897, 901, 288 N.Y.S.2d 888, 894 (1968); R. NelsoN, supra note 16, at 64; Haar, supra note 33, at 1155; Nelson, supra note 15, at 716-17 (quoting Dunham, Property, City Planning and Liberty, in LAV' AND LAND, ANOLO-AMERican Planning Practice 33-34 (C. Haar ed. 1964)).

159. Bownds v. City of Glendale, 113 Cal. App. 3d 875, 880-81, 170 Cal. Rptr. 342, 345-56 (1980); O'Loane v. O'Rourke, 231 Cal. App. 2d 774, 784-85, 42 Cal. Rptr. 283, 289 (1965); Haar, The Master Plan, supra note 100, at 365.

160. Alan Altschuler, in his classic study of planning in the Twin Cities, observed that local political figures did not think in the long-range and generalized terms implicit in general planning; they were bored by what they saw as abstract exercises and did not take the plans seriously. A. AlTSCHULER, supra note 152, at 139-41, 310-11; see also Lindblom, The Science of "Muddling Through," 19 PuB. AD. REv. 79, 88 (1959). Analogous complaints surfaced more recently in Florida as the state legislature considered its current mandatory planning act; local officials clearly resented the expense that they would have to undertake on a chore they regarded as at best marginally useful. Lewis, Florida's Cities Bite the Planning Bullet, Planning, Feb. 1979, at 25. 
problems help to focus attention, and lead to superior collection and evaluation of information. ${ }^{161}$ This view suggests that local councils might well give less careful consideration to an advance general plan than they do to an actual, specific proposal.

Moreover, since plans are supposed to reflect public participation-an increasingly important element in modern planning doctrine ${ }^{162}$-advance general planning might fail precisely because public attention may not coine into focus until the plan's implications become concrete. ${ }^{163}$ Consider, for exainple, De Sena v. Gulde, ${ }^{164}$ in which a municipality's general plan called for light industry in what appeared to be a black residential area. Apparently at a developer's request, a particular parcel was rezoned to conforin to the plan, and the neighborhood protested vigorously. The council backed down, and restored the residential zone. The developer sued and won; in the court's view, the city should have inaintained the light industrial rezoning, since inere protest was insufficient reason to abandon an ordinance that carried out a plan. ${ }^{165}$ The question raised here is whether the original plan itself received either as careful attention or as inucl public participation as the rezoning did; an actual project, and the controversy surrounding it, inay have focused inore attention and brought inore consideration to bear than the earlier and necessarily more abstract plan. Jane Jacobs, a notable critic of planning, has argued that in the absence of a specific project, planners might assume without real consideration that certain uses always aid or hann others; in fact, however, the "nonconforming" funeral hoine or factory may actually stabilize its residential neighborhood. ${ }^{166}$ Then too, a local government bent on circumventimg controversy might use an abstract plan, which inakes a finding of "consistency" easier to arrive at, as a ineans of shutting off the debate that accoinpanies an actual project.

In the traditional view of the dispassionately considered general plan, the plan should replace the protections of a larger legislature, preserving dispassionate fairness and unhurried consideration in each land use decision. But because soine emotional involvement is a necessary part of attentive decisionınaking, the price of basing a decision on an

16I. I. Janis \& L. ManN, Decision-Making 204-07 (1977).

162. Kaufman, Contemporary Planning Practice: State of the Art, in Planning IN AMERICA 115-16 (D. Godschalk ed. 1974). Kaufman stresses, however, that the practices and goals of planning have not changed greatly over the years. $I d$. at $118,128$.

163. Lefcoe, supra note 15, at 490-94; Lindblom, supra note 160 , at 81 . The same criticism applies to Kmiec's proposal, see Kmiec, Deregulation, supra note 15, for regulation of "land use intensity." Kmiec would limit public participation to the advance general discussion of desirable mixes of land use intensities, prior to any actual development project. Id. at 83-84.

164. 24 A.D.2d 165, 265 N.Y.S.2d 239 (1965).

165. Id. at 171,265 N.Y.S.2d at $245-46$.

166. J. Jacobs, The Death and Life of Great American Cities 232-33 (1961). 
advance plan may be that a vague, abstract, or incompletely aired "advisory opinion" is substituted for an overheated decision. ${ }^{167}$

Modern planning doctrine recognizes these problems. At least since Charles Lindbloin's 1959 plea for "muddling through,"168 modern planners have shown increasing dissatisfaction with the traditional "end-state" general plan, agaimst which current proposals are measured. They have derided the utopian character of such plans, ${ }^{169}$ and for the past decade have insisted that the plan should not be seen as an end-state depiction of goals determined in advance, but as a "process" of continual readjustments of goals and pohicies. ${ }^{170}$ Reflecting this view, the ALI's model land developinent statute calls for a periodically revised plan, ${ }^{171}$ and recent planning doctrine stresses that plans inust be up to date. ${ }^{172}$ Such a conception of planning rejects the notion of the plan as a portrait of the final goal toward which current land decisions strive, and instead treats planning inuch more as an ongoing process by which decisionmakers take a "hard look"173 at the long-terin decisions involved in land developinent. So conceived, planning blurs into the "inipact analysis" familiar in environmental law, and becomes equated with "being especially careful."174 The equation even seenus to justify some of the older zonmg decisions that took the SZEA language, "in accordance with a general plan," to nean only "well-considered."175

The modern idea does not mean that planning no longer occurs. It still does, but the steps taken to promote valued land uses may change the values themselves. Thus, for example, inodern federal planning

167. Brooks suggests that the general plan may paper over disagreements that only emerge at the point of implementation. Brooks, The Law of Plan Implementation in the United States, 16 URB. L. ANN. 225, 269-70 (1979). See also A. Altschuler, supra note 152, at 324.

168. See Lindblom, supra note 160.

169. H. GANS, supra note 152, at 62; M. SCOTT, supra note 2, at 245; Bolan, Mapping the Planning Theory Terrain, in PlanNiNg IN AMERicA, supra note 162, at 13, 24; Krasnowiecki, supra note 29, at 1032, 1038. See also Lindblom, supra note 160; Riesman, Some Observations on Community Plans and Uiopia, 57 YALE L.J. 173 (1947). For a discussion of Utopian planning, see L. Benevolo, The Origins of Modern Town Planning 39-84 (1971).

170. Lindblom, supra note 160 , is an early major source of the incrementalist view of planning. See also H. GANS, supra note 152 , at 65 . Soine recent planning enabling legislation attempts to incorporate the view of planning as a process, and provides for periodic review of plans. See, e.g., Fla. Stat. ANN. $\S 163.3191$ (West Supp. 1982); Model Land Dev. Code $\S \S 3-104,3-$ 105, 3-107 (1975).

171. See supra note 170 .

172. See, e.g., Mandelker \& Netter, supra note 17, at 57.

173. Natural Resources Defense Council, Inc. v. Morton, 458 F.2d 827, 838 (D.C. Cir. 1972).

174. MODEl LAND DEv. CODE \& 3-106 comment (ALI Code's scheme is to "focus legislative attention on problems of physical development . . a and on concrete programs aimed at their solution").

175. Haar, supra note 33 , at $1170-73$. 
statutes for historic preservation ${ }^{176}$ and for the federal agency management of public lands ${ }^{177}$ suggest that the very process of mventorying valued resources can jog the planners' imagmation as to what may be desirable for the future; ${ }^{178}$ and where desired ends compete (as, for example, preservation may compete with recreational use), ${ }^{179}$ the choice among desired goals alters the range of goals available in the future.

But the more modest, modern conception of planning as a rolling process is quite different from the conception inplicit in plan jurisprudence. ${ }^{180}$ Planning-as-process cannot be reconciled with a characterization of the plan as a standard by which to judge individual land decisions. If the plan is a "process," requiring constant (or at least periodic) alterations accordmg to new conditions, and if specific policy decisions are choices within a range of sometnnes competing long-term goals, ${ }^{181}$ then "plan consistency" is a shifting concept, and could mean a return to the case-by-case decisionmaking that consistency doctrimes were supposed to overcome.

By the same token, the quasi-judicial character of land decisions becomes much more problematic. Perhaps because of the difficulties of using planning-as-process as a standard for decision, some quasi-judicial treatments of land decisions have played down the role of the plan as a set standard. ${ }^{182}$ The difficulty here is that the absence of preexistimg standards weakens the case for treating these decisions as quasijudicial in the first place. ${ }^{183}$ They are so treated because they apply a

176. National Historic Preservation Act, Pub. L. No. 89-665, 80 Stat. 915 (codified as amended at 16 U.S.C. $\$ \S 470-470 \mathrm{a}, 470 \mathrm{~b}, 470 \mathrm{c}$ to $470 \mathrm{w}-6)$.

177. Federal Land Policy and Management Act of 1976, 43 U.S.C. § 1711 (1979).

178. Wemberg, Super List, Historic Preservation, July-Aug. 1982, at 10-11. For a discussion of the importance of inventorying in resource management, see S. HAYS, supra note 60, at 69 .

179. Sax, Fashioning a Recreation Policy for our National Parklands: The Philosophy of Choice and the Choice of Philosophy, 12 Creighton L. Rev. 973 (1979); see also Utah v. Andrus, 486 F. Supp. 995, 1003 (D. Utah 1979) (competing goals within federal land policy planning statute).

180. The Fasano court itself commented on the inflexibility that could accompany the quasijudicialization of land cliange decisions. 264 Or. at 587-88, 507 P.2d at 29-30.

181. Even in Oregon, a center of plan jurisprudence on the local level, the courts have recognized that state-level plans may "contain a variety of sometimes-mconsistent land-use objectives," and thus local efforts to meet these goals can do no more than "accommodate as inucli as possible all applicable planning goals." South of Sunnyside Neighborlıood League v. Board of Comm'rs, 27 Or. App. 647, 654, 557 P.2d 1375, 1380-81 (1976); see also 1000 Friends of Oregon v. Board of County Comm'rs, 32 Or. App. 413, 426-27, 575 P.2d 651, 656-57, petition denied, 284 Or. 41, 584 P.2d 1371 (1978).

182. Model LaNd Dev. Code $\$ \S 2-304,2-312$ (1975). See also Kropf v. City of Sterling Heights, 391 Mich. 139, 164, 215 N.W.2d 179, 190 (1974) (Levin, J., concurring).

183. An example is the very loose judicial review of modern federal statutes governing the management of the public domain. Several of these statutes envision multiple uses of the public lands, and thus "planning" here entails choice among competing goals rather than a fixed endstate; planning statutes of this sort lave been interpreted as allowing very broad discretion to managing agencies, reviewable only for arbitrariness. See, e.g., Perkins v. Bergland, 608 F.2d 803 (9th Cir. 1979). 
preexisting policy, and in the absence of a stable preexisting policy, the quasi-judicial process has no point of refcrence.

In some cases, to be sure, an end-state plan, or at least one that projects a desirable state for a long time, may be perfectly reasonableif we know what we want. An aspect of coastal planning is an example. For all the multimillion dollar questions of offshore mineral leases and coastal condominiums, one major issue in coastal manageinent is preserving the beach as a recreational and visual resource. ${ }^{184}$ At least one desirable end-state is easy to envision: its natural state. Even though it is impossible botli to use the beach and to leave it completely unspoiled, a utopian or fixed plan makes some sense here, because we do in fact liave an image of the ideal, and can determine its elements witl some precision. Similarly, built-up areas and established neighborloods are susceptible to a utopian vision, which again is often simply stasis, or at least no major change. It is no wonder that, as Richard Babcock and Clifford Weaver liave remarked, classic zoning is alive and well in urban neighborhoods. ${ }^{185}$ In these areas too we know what we want, i.e., essentially what is there now. This knowledge can shape an end-state plan; indeed, we have already arrived at the end-state, and the "plan" can provide a standard by which to judge imdividual land use decisions. ${ }^{186}$

But the traditional end-state plan is least appropriate for developing areas, where-im the absence of concrete proposals-we seldom have a clear vision of the end-state we desire, or even what the intermediate states along the way will look like. ${ }^{187}$ These are also areas in which land use controls can make a substantial difference to the ultimate cliaracter of development. ${ }^{188}$ It is precisely here, however, that local governments most strongly resist the limitations that end-state planning would impose on their discretion.

184. See, e.g., CAL. Pub. Res. Code $\$ 30251$ (West 1977) (development to be sited and developed to protect views of ocean and minimize alteration of natural land forms).

185. C. Weaver \& R. Babcock, City ZoNing: The ONCE AND Future Frontier 182 (1979).

186. Historic zones are the best examples of plans in which the test for alteration is "compatibility" with existing structures. See Rose, Preservation and Community: New Directions in the Law of Historic Preservation, 33 Stan. L. Rev. 473, 508 (1981). Perhaps "coinpatibility" is the unspoken test for many if not all land use decisions in developed areas; historic district zones simply make this exphcit, and have a more rigid test of compatibility. For a discussion of the ambiguities inherent in the idea of "compatibility" or "harmony" in historic districts, see id. at 510-11.

187. D. MANDELKER, supra note 5, at 63-66, 103-04, 165. The difficulties of planning for undeveloped areas have long been recognized. See, e.g., National Planning Conference, New Horizons in Planning 56-59 (1937) (remarks of Wallace Penfield).

188. D. MANDELKER, supra note 5, at 45. 


\section{The Pattern of Local Practice}

Local governments exhibit a marked talent for evading close examination of the conformity of their regulations to preexisting plans. A venerable avoidance technique is vagueness; if the local government adopts a sufficiently vague plan, any land use ordinance arguably conforms. ${ }^{189}$ In addition, local governments have continued to develop new devices to retain "flexibility." All of these put the locality into the desirable position of being able to bargain ad hoc with individual developers. Variances and conditional use permits-greatly expanded since SZEA days-are also traditional; ${ }^{190}$ and in inore recent years we have seen inore elaborate devices suclı as "floating zones," 191 "planned unit developinents," 192 and "developinent rights transfers,"193 all of which tacitly admit that a locality lias no fixed plan for appropriate developinent, but instead wants to deal with individual projects as they arise. ${ }^{194}$ And even if localities do have a plan, they often do not intend to stick by it; they retain case-by-case control by zoning land for uses slightly different froin the predicted developinent, and by modifying the original zoning with individual variances or rezoning ainendments on the developer's request. ${ }^{195}$

The inandatory planning statutes and Fasano-like decisions are efforts to force development decisions into a nore fixed pattern, ${ }^{196}$ and to avoid precisely the ad hoc decisioninaking that local legislatures clearly prefer. But such requireinents are unlikely to quash local inventiveness in retaining ad hoc control. When required to conform regulations to their respective inaster plans, for example, a number of California jurisdictions altered not the regulations but the plans. ${ }^{197}$ The California

189. See, e.g., Green v. Hayward, 275 Or. 693, 704, 552 P.2d 815, 821 (1976); McMillan v. American Gen. Fin. Corp., 60 Cal. App. 3d 175, 131 Cal. Rptr. 462 (1976).

190. R. BABCOCK, supra note 4, at 7-10. The discretionary "conditional use" permit, granted without respect to plan consistency, appears to be capable of surviving new nandatory planning and consistency requirements. See, e.g., Hawkins v. County of Marin, 54 Cal. App. 3d 586, 126 Cal. Rptr. 754 (1976); Sierra Club v. County of Alameda, 73 Cal. App. 3d 572, 140 Cal. Rptr. 864, officially depublished pursuant to CAL. CT. R. 976(d), 572 P.2d 755, 142 Cal. Rptr. 696 (Sup. Ct. 1977) (en banc).

191. See, e.g., Rodgers v. Village of Tarrytown, 302 N.Y. 115, 96 N.E.2d 731 (1951); cf. Eves v. Zoning Bd. of Adjustment, $401 \mathrm{~Pa} .211,164 \mathrm{~A} .2 \mathrm{~d} 7$ (1960) (invalidating township's attempted rezoning as not in accordance with coinprehensive zoning plan).

192. Krasnowiecki, Planned Unit Development, supra note 104.

193. See, e.g., Costonis, Development Rights Transfer: An Exploratory Essay, 83 YALE L.J. 75 (1973).

194. Model Land Dev. Code $\$ \S 196-200$ (Tent. Draft No. 1, 1968).

195. Id. See also Booth, supra note 107, at 764; Krasnowiecki, supra note 29, at 1033-34, $1048-49$.

196. Fasano, 264 Or. at 582-84, 507 P.2d at 27-28; Camp v. Mendocino Bd. of Supervisors, 123 Cal. App. 3d 334, 176 Cal. Rptr. 620 (1981); see also C. WEAVER \& R. BABCocK, supra note 185 , at $271-72$.

197. Brooks, supra note 167 , at $243-44$. For cases involving plan clianges inade simultane- 
legislation mandating local planning has now taken the precaution of forbidding localities to alter the underlying plan more frequently than three times a year. ${ }^{198}$ But California cities have already begun to circumvent the thrice-yearly limitation by saving up individual pieceineal changes for seasonal plan changes en masse. ${ }^{199}$ In the face of mandatory planning, Mendocmo County revived a classic flexibility device-the vague plan-in a "plan" that consisted of a box of various unrelated reports and memoranda. ${ }^{200}$ The insistence of the state's attorney general seems to have pushed the county into a more definite statement of its planning standards. ${ }^{201}$ But given the fertility of the local legislative imagination in protectimg ad hoc control over mdividual land development projects, we inay expect new flexibility devices to sprout in the wake of planning statutes and Fasano-like cases. ${ }^{202}$

Such irrepressible inventiveness casts some doubt on the legislative or judicial capacity to insist on a detailed advance plan as the standard by which later decisions are tested. If a master plan is vague, easily changeable, or packed with opportunities for the use of flexibility devices, then virtually any land use regulation can "conforn" to the plan. ${ }^{203}$ And if this is so, statutory consistency may be trivialized, and all the quasi-judicial procedures in applying the plan become an elaborate charade-and so does judicial review of those quasi-judicial decisions.

ously with zoning changes, see Mountain Defense League v. Board of Supervisors, 65 Cal. App. 3d 723, 135 Cal. Rptr. 588 (1977). See also Winkelman v. City of Tiburon, 32 Cal. App. 834, 108 Cal. Rptr. 415 (1973). For a Washington case involving simultaneous change, see Barrie v. Kitsap County, 93 Wash. 2d 843, 852, 613 P.2d 1148, 1154 (1980).

198. CaL. Gov't Code $\$ 65361$ (a) (West Supp. 1982).

199. Mandelker, Sullivan, Kane \& Beatty, Mandatory Comprehensive Planning: A Perspective from Three States, in LAND USE LAW: IsSUES FOR THE ElGHTIES 85, 89 (E. Netter ed. 1981).

200. Camp v. Mendocino County Bd. of Supervisors, 123 Cal. App. 3d 334, 349 n.8, 176 Cal. Rptr. 620, 630 n.8 (1981).

201. Id.

202. See, e.g., Hawkins v. County of Marin, 54 Cal. App. 3d 586, 126 Cal. Rptr. 754 (1976) (consistency requirement not apphed to individual conditional use permit where general zoning ordinance is consistent with plan). For a discussion of some gaps im California's mandatory planning and consistency requirement, widely regarded as the most stringent in the nation, see Hagman, Inconsistency on Mandatory Planning and Consistency, LAND UsE L. \& ZONINo DiG., May 1982, at 5,6. But see Stemer \& Abbot, id. at 7 (reply).

203. For California cases dealing with ambiguous or nonexistent plans or standards, see Sierra Club v. County of Alameda, 73 Cal. App. 3d 572, 140 Cal. Rptr. 864 ("general welfare" sufficient standard for conditional use perinit), officially depublished pursuant to $\mathrm{CAL}_{\mathrm{AL}} \mathrm{CT}$. $\mathrm{R}$. 976(d), 572 P.2d 755, 142 Cal. Rptr. 696 (Sup. Ct. 1977) (en banc); McMillan v. American Gen. Fin. Corp., 60 Cal. App. 3d 175, 131 Cal. Rptr. 462 (1976) (upholding local "consistency" finding where plans ambiguous). Cf. Save El Toro Ass'n v. Days, 74 Cal. App. 3d 64, 141 Cal. Rptr. 282 (1977) (invalidating subdivision approval because it could not be consistent with a nonexistent plan). For discussions of plan vagueness in other states, see Green v. Hayward, 275 Or. 693, 552 P.2d 815 (Or. 1976); Kalakowski v. John A. Russell Corp., 137 Vt. 219, 225-26, 401 A.2d 906, 910 (1979). 
Legal commentators have deplored local governments' evasions of planning, and their unwillingness to deal with development proposals in the generalized way implicit in the idea of planning. But except for beaches and other areas where we can envision the desired end-state, these repeated local efforts to evade end-state planning confirm the planning theorists' doubts about such plans, and suggest that the plan/implementing ordinance model simply may not be compatible with the local land use decisionmaking process. This local process seems to move in the direction of more bargaining, more participation, and more personal knowledge and one-on-one contact. An effort to make local decisionmakers behave in a markedly different manner might well backfire, encouraging false and evasive plans, and false and evasive escapes therefrom. We do not want plan consistency or quasijudicial procedures for themselves; we want them to ensure care and fairness in the local land decision process.

To a very considerable degree, the emergence of plan jurisprudence is the work of the courts, as they have sought some way to subject local land decisions to meaningful review in order to ensure carefulness and fairness. ${ }^{204}$ As the courts and critics have rightly perceived, these decisions should not be treated as legislative acts. They are too limited to bring forth the clash of interests and the coalitionbuilding processes that restrict legislatures when they enact general measures and that justify a loose review of those measures. But, as I have argued in this Part, the effort to quasi-judicialize these piecemeal changes, and to subordinate thein to an advance plan, at once asks too much and too little: too inuch in supposing that local governments, in the absence of concrete proposals, can look far into the future and state guidelines by which to adjudicate future decisions; too little in that the plan itself may be too abstract or too partisan to guide future development fairly, or indeed to check ineaningfully the exercise of local discretion-even where that discretion is dressed up as the quasi-judicial application of a plan.

Thus, piecemeal changes are no more quasi-judicial than they are legislative. Indeed, the rubric "quasi-judicial" leads to confusion about the procedures that are appropriate for piecemeal changes, and perpetuates a rigid, unrealistic conception of planning.

We have arrived, then, at a point where it appears that "piecemeal change" local land decisions defy our normal governmental categoriza-

204. Brooks, supra note 167, at 252-54; Griffin \& Becker, supra note 10, at 632-34; Krasnowiecki, Planned Unit Development, supra note 104, at 74-77. For an example of the courts' stress on their need for a basis of review, see, for example, City of Rancho Palos Verdes v. City Council, 59 Cal. App. 3d 869, 886-88, 129 Cal. Rptr. 173, 181-82 (1976); Parkridge v. City of Seattle, 89 Wash. 2d 454, 463-64, 573 P.2d 359, 365 (1978). Cf. P. Nonet, supra note 99, at 181. 
tions, and escape the safeguards built into those categories. Neither "legislative" nor "adjudicative" characterizations encompass the full range of considerations attendant upon these small changes; moreover, neither seeins capable of ensuring due consideration and fairness in these decisions. The remainder of this Article argues for a different approach to piecemeal local land decisions, an approach that treats them neither as legislation nor as adjudication, but as what they have been pejoratively called: deals.

\section{III}

\section{Alternative Traditions, Alternative Approaches}

This Article has concentrated on plan jurisprudence because, despite its difficulties, it contains at least two important ideas about piecemeal changes and why they are so problematic. As to the decisionmaker, plan jurisprudence recognizes that local governmental bodies cannot be treated as legislatures, whose actions are legitimized and safeguarded by the fragmentation of interests and the give-andtake of coalition-building. As to the changes themselves, plan jurisprudence recognizes that sucl changes are guided not so much by generally applicable rules as by a desire to adjust conflicting claims about property development made by limited numbers of claimants. ${ }^{205}$ Thus, piecemeal land use decisions cannot be legitimized by seeing them as parts of a legislative stacking of coalition decisions, since the parties deal with each other at inost intermittently.

Plan jurisprudence recognizes that alternative safeguards are needed precisely because the legislative safeguards may be missing. The msights of plan jurisprudence can, however, inform a jurisprudence that does not rely on the transforination of piecemeal changes into judicial actions. Let us then reexamine these two fundamental aspects of piecemeal changes: (1) the local character of the decisionmakers, and (2) the dispute-resolving character of the change decision.

\section{A. The Local Context: Alternative Bases of Legitimacy}

One of the most striking facts about pieceneal land changes is that they are constantly left to local governmental bodies. ${ }^{206}$ Why imdeed

205. See, e.g., Fleming v. City of Tacoma, 81 Wash. 2d 292, 299, 502 P.2d 327, 331 (1972) (zoning amendment adjusts rights of proponents and opponents of the zoning change); Hyson v. Montgomery County Council, 242 Md. 55, 65-67, 217 A.2d 578, 585 (1966) (legislative decisions involve general rules while quasi-judicial decisions settle contested cases). For zoning as a definition of collective property rights, see Nelson, supra note 15 , at 720 .

206. This is true even in the Quiet Revolution proposals to centralize some portions of land use control in the state; the bulk of everyday land control decisions would continue to be local. See supra note 12 and accoinpanying text. 
should local bodies, with their blurring of the tripartite separation of powers, ${ }^{207}$ their lack of conventional Federalist restraints, and their consequent susceptibility to corruption, unfair influence, and majoritarian pressure-why should this level of government be charged with these sensitive adjustments of individual property rights?

Albert Hirschman's highly imagmative book, Exit, Voice, and Loyalty $^{208}$ suggests some answers and soine bases for a theory of local legitimacy distinct from Federalist-based political thought. Hirschman began by asking why competition did not suffice to improve the quality of some firms' output-that is to say, why the customer's ever-present option to "exit" to a competitor failed to prod the firms into improving the quality of their products. He concluded that improvenent in quality often required that some customer make an articulated effort to change things, which Hirschman called "voice,"209 an effort which is precluded when exit is too easy. Thus in situations where quahty of output especially matters, the ideal institutional structure coinbimes opportumities for voice with at least a limited opportunity for exit as a threat behind voice. ${ }^{210}$ Reinforcing voice, without entirely foreclosing exit, is what Hirschman calls "loyalty": a preference for sticking with the institution, and for attempting to change matters rather than leaving. ${ }^{211}$

Hirschman found a potential for the ideal combimation of exit and voice, reinforced by loyalty, in certain types of institutions, notably political parties and volunteer organizations. ${ }^{212}$ But local government can also combine Hirschman's elements. Indeed, an alternative tradition in American political thought has virtually always stressed the possibility of participation and the option of going elsewhere to legitimize local authority.

Participation or voice is a particularly venerable legitimator of local government. ${ }^{213}$ While The Federalist is our chief text for the legiti-

207. For a recent example of the mixture of functions, see Village of Covington v. Lyle, 69 Ohio St. 2d 659, 433 N.E.2d 597 (1982) (upholding a "mayor's court"). The mixture of local functions is also refected in such quaimt local titles as "pohce jury" (Louisiana parish governing board) and "fiscal court" (Kentucky county governing board). Plan jurisprudence in effect reflects the mixture of legislative and judicial functions in local councils, and attempts to classify particular actions as belonging to one or another function.

208. See A. HiRschman, supra note 23.

209. Id. at 30 .

210. Id. at $53,55,120-23$.

211. Id. at 77 .

212. Id. at 121

213. See, e.g., Scheiber, Federalism and Legal Process: Historical and Contemporary Analysis of the American System, 14 LAW \& Soc'y REv. 663, 689-90 (1980); Sandalow, supra note 71, at 709-10. Sandalow is skeptical of the "closeness to the people" justiflcation, however, for reasons drawn from The Federalist No. 10. For a sympathetic account of the argument for local goverument as a focus for civic participation, see Frug, supra note 54, at 1068-71. 
macy of large-scale government, the Federalists' contemporary opponents, the so-called Antifederalists, advocated a government of local participation and citizen control.

The Antifederahists' treatment of representation is particularly striking for its doctrine of local participation. ${ }^{214}$ For them, representation was a second-best substitute for direct popular government, ${ }^{215}$ and was feasible only im small districts. Here representatives personally know and share the concerns of their constituents, and they can-in a widely shared eighteenth-century view of representation- "mirror" or "picture" the various constituencies. ${ }^{216}$ Thus the Antifederalists opposed the Federahists' large "consolidated government,"217 with its necessarily large electoral districts. These distant and false representatives would enact laws to which the people did not genuinely consent, because the laws were not made by the citizens themselves, or by persons like them. ${ }^{218}$

The Antifederalists' stress on the consensual and participatory character of government and their vision of the nation as a collection of self-defining communities ${ }^{219}$ had deep roots in the past and was reflected as well in contemporary European political thought and prac-

214. See generally Storing, What the Anti-Federalists Were For, in 1 THE CoMplete ANTIFEDERALIST 15-23 (H. Storing ed. 1981) [hereinafter cited as ANTI-FEDERALIST].

215. 2 Elliot, supra note 64, at 227-28 (speech of M. Sinith in New York ratifying convention); see also Speeches by Melancton Smith, in 6 ANTI-FEDERALIST, supra note 214, at 148-76. 1 cite Elliot in the hope that the reader inay be drawn to read the extraordinary exchanges between Smith and Alexander Hamilton. See also Storing, supra note 214, at 17-18.

216. C. KenYon, The ANtifederalists lii (1966). For the use of the "picture" metaphor, see 2 Elliot, supra note 64, at 245 (speech of M. Smith in New York ratifying convention); 3 id. at 32 (speech of G. Mason in Virginia ratifying convention). On this "pieture" version of the ineaning of representation generally, see H. PITKIN, supra note 62, at 60-61. See also Observations Leading to a Fair Examination of the System Of Government Proposed by the Late Convention; And to Several Essential and Necessary Alterations in It. In a Number of Letters from the Federal Farmer to the Republican [hereinafter cited as Letters from the Federal Farmer], in 2 ANT1-FEDERALIST, supra note 214, at 214, 267-69 (attributed to R.H. Lee); 3 Elliot, supra note 64, at 322 (speech of $P$. Henry in Virginia ratifying convention) (the people should be "acquainted with the candidates" and enjoy "a confidential connection between the electors and the elected"); Speeches of Patrick Henry in the Virginia State Ratifying Convention, in 5 ANTI-FEDERALIST, supra note 214, at 207-54; Speech of George Mason in the Virginia State Ratifying Convention, in 5 ANTI-FEDERALIST, supra note 214 , at 255-59.

217. C. KENYON, supra note 216, at xlii-xliii; Storing, supra note 214, at 10.

218. 2 Elliot, supra note $64,227,245-48$ (speech of M. Smith in New York ratifying convention). See also Letters of Centinel, in 2 ANTI-FEDERALIST, supra note 214, at 130, 142 (attributcd to Sainuel Bryan); Essays of Brutus, in 2 ANTI-FEDERALIST, supra note 214, at 358, 369, 379-80 (attributed to Robert Yates). These authors frequently expressed the view that only persons of wealth and stature-the "natural aristocracy"-could be electcd in large districts, and that sueh persons would not understand or sympathize with the interests of the "yeomanry." See, e.g., id. at 384-86; Letters from the Federal Farmer, supra note 216, in 2 ANTI-FEDERALIST, supra note 214, at 264-70.

219. Storing, The Problem of Big Government, in A Nation of States 67, 70-71 (R. Goldwin ed. 1974); see also Essays of Brutus, in 2 ANTI-FEDERALIST, supra note 214, at 274. 
tice. ${ }^{20}$ Perhaps it is not surprising that despite The Federalist's domination of mainstreain American thinking about representation, the quite antithetical Antifederahist tradition has stubbornly persisted in American discussions of local government, though in fragmentary form. The behef that locahities were best equipped to govern themselves underlay the "home rule" inovement in the nineteenth century, ${ }^{221}$ and the corollary that local government is particularly responsive has reemerged in the rhetoric of "citizen participation" and of local government's "closeness to the people" in inore recent federal programs to assist local governments. ${ }^{222}$ Indeed, it is implicit in the charge that local governments have not fully engaged the entire spectrum of the citizenry in their decisions. ${ }^{223}$ The charge suggests that we expect that local government should be a "picture" of the local populace, giving voice to its various eleinents.

Aside from scholarly work directly advocating decentralization of government, ${ }^{224}$ commentators occasionally lend inore oblique support to the notion of local responsiveness. In soine historians' recent reassessments of the inuch-decried corruption of nineteenth century cities, for example, the political bosses and machmes have been treated witl a certain sympathy, and with some respect for the inachines' achievement in integrating immigrants imto American life. ${ }^{225}$ Despite its cor-

220. Diamond, What the Framers Meant by Federalism, in A NATION OF STATES, supra note 219. at 25, 35-37. The most notable contemporary was of course Rousseau. See Rousseau, The Social Contract, in THE Social ConTract ANd Discourses bk. 2, ch. 9 (G. Cole trans. Dutton ed. 1950). Montesquieu also thought popular rule compatible only with small-scale government. See Diamond, supra, at 36. The then novel and experimental idea was the notion of representation in an extended republic where no popular consensus was required save a willingness to accept the adventitious outcomes of the coalition-building process. See Beer, Federalism, Nationalism, and Democracy in America, 72 AM. POL. ScI. ReV. 9, 13-14 (1978).

221. C. Adrian \& E. Griffith, A History of American City Government: The ForMATION OF TRADITIONS, 1775-1870, at 41-43 (1976); Sandalow, supra note 71, at 647-48 (home rule movement seen as a reaction against state corruption of local affairs). As a reaction against state imtrusion into local affairs, the home rule movement may be a particularly interesting comparison to the Quiet Revolution efforts to increase state involvement in local land decisions. See supra notes 4, 12-24 and accoinpanying text. Not all home rule advocates were particularly deinocratic, however. On differences within the home rule position, see M. HOLLI, REFORM IN DETROIT 169-81 (1969).

222. Susskind, Revenue Sharing and the Lessons of the New Federalism, 8 URB. L. ANN. 33, 36, 42 (1974).

223. Id. at 45-51. For my own minor contribution to this literature, see C. Rose, Citizen Participation in Revenue Sharing: A Report froin the South, reprinted in Proposed Extension of the State and Local Fiscal Assistance Act: Hearings on H.R. 6558 and Related Bills Before the Subcomm. on Intergovernmental Relations and Human Resources of the House Comm. on Government Operations, 94th Cong., 1st Sess. 628 (1975).

224. See Beer, supra note 220 , at 9.

225. See, e.g., E. Griffith, A History of American City Government: The Conspicuous Fallure, 1870-1900, at 63-69 (1974); S. WARner, The Private City 156 (1968); Cornwell, Bosses, Machines, and Ethnic Groups, in THE CITY Boss IN AMERICA 124-38 (A. Callow ed. 1976). The "inachine" was sometimes a vehicle for the entry of former slaves into civic life as well. See 
rosion of civic well-being, the machine and its neighborhood precinct organization emerge in some ways as the Antifederalist ideal of a political mirror reflectimg even the meanest citizens; ward boss representatives certainly mingled with their constituents and knew them well, and helped to accommodate the needs of very different population groups through highly personal assistance. ${ }^{226}$

Perhaps less familiar in the alternative tradition is the idea of exit to legitimize local authority, but the opportunity for exit has been a constant threat behind voice at the local level. Dissenters in colonial New England villages punctuated their demands to be heard by threatening-and occasionally acting on their threats-to withdraw to form their own communities. ${ }^{227}$ In the early days of the republic, departure to form new communities was an outlet for dissatisfaction, a pattern seen perhaps most strikingly in utopian communities. ${ }^{228}$ More recently, the political economist Charles Tiebout suggested that local governments (unlike the national government) resemble competimg firms, each offering a package of goods, services, and amenities, and clrosen by its residents for those reasons. ${ }^{229}$ Thus our seemingly irrational metropolitan divisions, with their vast numbers of separate political units, in fact offer the safeguard of exit, so that individuals may clroose their neighbors and the polity within which they can preserve their preferences. ${ }^{230}$

None of this is to romanticize local politics, but rather to suggest that local government unay be legitimized by factors unlike those that legitimize government on a larger scale. As we have seen, in a large government, legislative fairness and carefulness is assured by the shifting coalitions among interest groups; and judicial fairness and carefulness arise from the application of consistent norms by msulated and

Landmarks Heritage Preservation Comm'n, A Comprehensive Program for Historic PRESERVATION IN OMAHA 57 (1980).

226. E. GRIFFITH, supra note 225, at 72-73; S. WARNER, supra note 225, at 156; Cornwell, supra note 225, at 127; Handlin, Why the Immigrant Supported the Machine, in THE CITY Boss IN AMERICA, supra note 225, at 98-102. For a comparison to today's city politics, see Purnick, New York Blacks Say They've Lost Political Power, N.Y. Times, Mar. 29, 1981, \& 1, at 1, col. 2 (demise of "machine" means end of ethnically balanced political tickets).

227. K. Lockridge, a New England Town: The First Hundred Years: Dedham, MAss., 1636-1736, at 100-16 (1970).

228. See generally A. Bestor, Backwoods Utopias (2d ed. 1970); A. Tyler, Freedom's FERMENT 108-224 (2d ed. 1962).

229. Tiebout, A Pure Theory of Local Expenditures, 64 J. PoL. Econ. 416, 418, 423 (1956).

230. Id ; cf. Grubb, The Dynamic Implications of the Tiebout Model: The Changing Composition of Boston Communities, 1960-1970, 10 PUB. FIN. Q. 17 (1982) (challengimg Tiebout's theory with use of sociological data). Some approval of a pattern of local differentiation may be implicit in Village of Belle Terre v. Boraas, 416 U.S. 1 (1974) (upholding local land regulations that sharply restricted nonfamily living arrangements). But see Moore v. City of E. Cleveland, 431 U.S. 494 (1977) (striking down ordinance that had restrictive definition of family). 
impartial judges. The legitimacy of local decisionmaking, on the other hand, may derive from interested parties' opportunities for a combination of Hirschman's eleinents: voice in the ability to participate in decisions, and in having decisionmakers who know the issues directly and who try to secure the parties' acceptance of a final decision and their continued integration in the community; and exit in the parties' ultimate opportunity to withdraw and go elsewhere. The Federahists rejected this understanding of government, ${ }^{231}$ but they spoke chiefly to justify national government. In local government, it inay be appropriate to look to a form of decisionmaking that is neither legislative nor judicial in the Federalist model. ${ }^{232}$ This alternative inodel rests on more traditional legitimating factors: citizens' participation, backed by possible departure. Hence the first insight of plan jurisprudence-that the local bodies making pieceineal land decisions inay be unrehiable as legislatures in a Madisonian sense--nay lead us not to judicialization but to some solution outside the traditional separation of powers.

\section{B. Piecemeal Changes as Property Disputes: Mediation as a Resolution Process}

The second inajor insight of plan jurisprudence is that decisions naking piecenieal changes are different froin general legislative decisions. In treating these small change decisions as quasi-judicial applications of preexisting norms, plan jurisprudence in effect treats them as resolutions of property rights disputes.

This dispute-resolving treatment brings piecemeal changes into theoretical alignment with the original purposes of public land use controls. Modern land use regulation began as an effort to forestall nuisances-that is, to prevent conflict over property interests claimed by two or inore parties, or at least to minimize the daniage that arises from the proximity of conflicting uses. ${ }^{233}$ Changes in land use regulation pit

231. Storing, supra note 219, at 81. See, e.g., 2 Elliot, supra note 64, at 254-57 (comments of A. Hamilton in the New York ratifying convention rejecting sinall districts that would have a low number of constituents per representative). Hamilton also had some unflattering things to say about the notion that the ideal form of self-government was direct democracy, for which representation was an imperfect substitute. Id. at 253 (The "very character [of direct deinocracies of the past] was tyramiy; their figure, deformity . . . an ungovernable nob, not only incapable of delibcration, but prepared for every enormity.").

232. As was suggested earlier, see supra text accoinpanying note 117 , the Eastlake decision implies that individual states can decide for themselves whether to characterize local land decisions as legislative or as judicial-and presumably they may characterize thein as soinething else altogether.

233. See, for exaunple, the ordinance limiting livestock holding and butchering locations in the famous Slaughter House Cases, 83 U.S. (16 Wall.) 36 (1872), and the statute restricting wharf extensions into a harbor in Commonwealth v. Alger, 61 Mass. (7 Cush.) 53 (1851). See also R. Lotchin, San Francisco 1846-56: From Hamlet to City 11-13, (1974). 
the proponent of change against the interests of neighboring property owners or some larger segment of the community. ${ }^{234}$ The dispute rests on conflicting views about the boundaries of property rights, which may be quite fluid. ${ }^{235}$

Of course, conflicts must be resolved fairly; we have seen that fairness is not automatic in local government. But adjudication is not the only fair resolution. Once we have freed ourselves from the idea that local government must act according to separation-of-powers doctrine (directly or in its "quasi" form in administrative law), we can turn to other dispute-resolving forms. Anthropological hiterature, 236 and, incrcasingly, modern legal literature, ${ }^{237}$ suggest negotiation and particu-

234. Cf. Kmiec, Deregulation, supra note 15, at 90-93 (arguing that neighbors should have no role in individual land use decisions). This view may follow from the author's conception of land use controls as essentially a tax on the development value of land, rather than as an effort to minimize adverse uses; he relegates adverse use problems primarily to the law of nuisance. Id. at 84. Closely related is the author's preference for large projects. Id. at 96 n.240. Presumably, this is in part because externalities can be internalized in large projects (except at the border) and the neighbors' objections to adverse uses may be lessened.

235. See R. Nelson, supra note 16, at 17 (inodern land regulation confers a collective property right on the neighborhood); Nelson, supra note 15, at 719-21.

236. For a discussion of this literature, see The Disputing Process-LAw IN TEN Societies 1-40, 351-61 (L. Nader \& H. Todd eds. 1978). See also P. Gulliver, Disputes and Negotiations: A Cross-Cultural Perspective (1979).

237. See, e.g. Eisenberg, Private Ordering Through Negotiation: Dispute Settlement and Rulemaking, 89 Harv. L. REv. 637 (1976); Fuller, Mediation-Its Forms and Functions, 44 S. CAL. L. Rev. 305 (1971). One exchange on the subject began with Danzig, Toward the Creation of a Complementary, Decentralized System of Criminal Justice, 26 STAN. L. REv. 1 (1973), and comments thereon by Felstiner, Influences of Social Organization on Dispute Processing, 9 LAw \& Soc'y Rev. 63, 86-87 (1974) [hereinafter cited as Felstimer, Influences]; Danzig \& Lowy, Everyday Disputes and Mediation in the United States: A Reply to Professor Felstiner, 9 Law \& Soc'Y REv. 675 (1975) (reply); Felstiner, Avoidance as Dispute Processing: An Elaboration, 9 LAw \& Soc'Y REv. 695 (1975) (response) [heremafter cited as Felstiner, Avoidance]. See also Galanter, Justice in Many Rooms, in ACCESs to Justice AND the Welfare State 147, 161-69 (M. Cappelletti ed. 1982); Susskind \& Weinstem, Towards a Theory of Environmental Dispute Resolution, 9 B.C. ENVTL. AfF. L. Rev. 311 (1980-81). For a discussion of recent European interest in dispute resolution through mediation and negotiation, see Gottwald, Alternativen zum zivilen Justizverfahren, 1982 ZeIrSChRIFT FÜr Rechrspolitik Heft 1, 28. See also Cappelletti \& Garth, Access to Justice and the Welfare State: An Introduction, in Access to Justice AND THE WELfare STATE 14-20 (M. Cappelletti ed. 1982). Contract or "rulenaking" negotiation (as distinguished froin dispute negotiation or mediation, see Eisenberg, supra, at 665) is of course central in collcctive bargaining in labor law, but there is currently also a new interest in dispute mediation in labor matters. See Goldberg, The Mediation of Grievances under a Collective Bargaining Contract: An Alternative to Arbitration, 77 Nw. U. L. REv. 270 (1982); Franklin, Costs and Tensions Cut in Mine Mediation Plan, N.Y. Times, July 11, 1982, § 1, at 16, col. 1. A cautionary appraisal of the applicability of anthropological inediation inodels to contemporary American institutions is made in Felstimer, Infiuences, supra; Garth, The Movement Toward Procedural Informalism in North American and Western Europe, A Critical Survey, in 2 The Politics of INFormal Justice 183, 196 (R. Abel ed. 1982); Merry, The Social Organization of Mediation in Nonindustrial Societies, in 2 THE PoLitics OF INFORMAL JUSTICE, supra, at 17,33-40. These authors stress that mediation depends on a pattern of ongoing relationships among parties; land use changes, of course, normally do involve long-term relationships between new developments and neighbors. 
larly mediation as an alternative dispute-resolving model especially appropriate at the local or sublocal level. ${ }^{238}$

This literature suggests the following schematic representation as a rough contrast between adjudicatory and negotiative/mediative dispute-resolving methods:

\begin{tabular}{|l|l|}
\hline \multicolumn{1}{|c|}{$\begin{array}{c}\text { Adjudication } \\
\text { Parties address third party }\end{array}$} & $\begin{array}{l}\text { Negotiation/Mediation } \\
\text { Parties address each other directly } \\
\text { or through third party mediator }{ }^{239}\end{array}$ \\
\hline $\begin{array}{l}\text { Third party is disinterested, } \\
\text { passive }\end{array}$ & $\begin{array}{l}\text { Third party may have stake in } \\
\text { successful resolution, takes active } \\
\text { part especially as spokesman for } \\
\text { community240 }\end{array}$ \\
\hline $\begin{array}{l}\text { Process narrows arguments and } \\
\text { information to address limited } \\
\text { number of formal principles }\end{array}$ & $\begin{array}{l}\text { Process expands argunents, } \\
\text { information }{ }^{241}\end{array}$ \\
\hline Norms are few in number, stable & $\begin{array}{l}\text { Norns are numerous, open ended } \\
\text { (nay overlap, shift in course of } \\
\text { proceeding) }\end{array}$ \\
\hline $\begin{array}{l}\text { Result is decision based on formal } \\
\text { primciples, one party wins and } \\
\text { other loses }\end{array}$ & $\begin{array}{l}\text { Result is accommodation of } \\
\text { parties, directed to their future } \\
\text { relations }{ }^{243}\end{array}$ \\
\hline $\begin{array}{l}\text { Result (decision) is basis for } \\
\text { future decisions }\end{array}$ & $\begin{array}{l}\text { Result (accommodation) is } \\
\text { suggestive but not decisive for } \\
\text { future accommodations }\end{array}$ \\
\hline
\end{tabular}

I have suggested at various points in this Article that proceedings for piecemeal changes are far more reahistically perceived as mediative than quasi-judicial. This is true with regard to the quimtessential small change, the variance: adjustment boards treat requests for special zoning treatment as potential sources of disputes, taking into account neighborhood protests and imposing conditions in order to reach

238. Danzig, supra note 237 , at 2-3.

239. P. GuLLIVER, supra note 236, at xvii, 3-5, 20-21, 210; see also Eisenberg, supra note 237, at 655; Felstiner, Infuences, supra note 237, at 69; Gulliver, Negotiations and Mediations, in Working Papers from the Program In LAW and Society, No. 3, at 1-3 (1973); Susskind \& Weinstein, supra note 237 , at 314.

240. P. GulLIVER, supra note 236, at 214-19; Fuller, supra note 237, at 338 (quoting $R$. BARTON, IFUGaO LAW 87 (1969)).

241. P. GuLliver, supra note 236, at 52; Danzig, supra note 237, at 43; Gulliver, supra note 239 , at 9; Susskind \& Weinstein, supra note 237 , at 5-7.

242. P. Gulliver, supra note 236, at 8-12; Eisenberg, supra note 237, at $642-46$ ("closed" vs, "open-ended"); Felstiner, Influences, supra note 237, at 70.

243. P. Gulliver, supra note 236, at 16-17; Danzig, supra note 237, at 43; Fuller, supra note 237, at 327. For a discussion of all-or-nothing decisions in the courts, see Coons, Approaches to Court Imposed Compromise-The Uses of Doubt and Reason, 58 Nw. U.L. REv. 750 (1964).

244. Eisenberg, supra note 237, at 649-53. 
accommodation. More sophisticated devices such as "planned unit developments" do the same (although sometimes on a larger scale): local boards attend to disputes and attempt to find packages of conditions that will lead to accommodation.

Even where the courts reject these "dealing" qualities and attempt to treat piecemeal changes quasi-judicially, they seem unable to avoid mediative forms, with the concomitant expansion of issues and accommodation-centered goals. A Kentucky intermediate court acknowledged this expansion: "[M]ost such proceedings involve emotional responses to technical issues .... Those opposed to any rezoning may be intimidated by an awesome formalistic procedure .... [A]ll parties who appeared were given ample opportunity to express their opinions .... [and] the public had a substantial opportunity to protest the zoning change ...."245 As to accommodation, a New York court remarked, in declining to interfere with the local board's special exception decision, that such issues "are best resolved by 'common sense judgments' of 'representative citizens doing their best to make accommodations between . . . community pressures.".246

A mediation model is more realistic and less distorting than plan jurisprudence in decipherimg not only the procedures of piecemeal changes, but also the relationships among planning, general ordinances, and piecemeal changes. ${ }^{247}$ In particular, if piecemeal

245. Fiscal Court v. Ogden, 556 S.W.2d 899, 901 (Ky. 1977).

246. Burger King Corp. v. Amelkin, 70 A.D.2d 627, 416 N.Y.S.2d 528 (1979) (quoting Lemir Realty Corp. v. Larkin, 11 N.Y.2d 20, 25, 181 N.E.2d 407, 409, 226 N.Y.S.2d 374, 377 (1962)).

247. Plan jurisprudence envisions the master plan as a relatively fixed document, which is implemented by a presumptively valid general ordmance; when the general regulation is in turn altered, the change is presumptively imvalid. A mediation model suggests a very different view of the plan/general ordinance/piecemeal change triad. First, a mediation model takes a much looser view of planning as a source of norms. Negotiative or mediative norms are open-textured in the sense that they may change, overlap, and, to some degree, exclude each other. See supra note 242. Thus, where planning is a source of norms, it entails not a fixed end-state, but rather the inventorying of valued resources, perceived problems, and desidirata for future development, where it is recognized that not all valued outcomes may be realized simultaneously but must be balanced against each other. An advance plan may thus act as a source of norms im a mediation process, but cannot set forth a definitive answer, nor can advance planning act as an exclusive set of norms, since actual decisions may raise other values and ultimately change the plan itself.

Second, in this model, a general zoning ordinance or other generally applicable land regulation is not a concrete implementation of some fixed plan, but rather a statement of threshold development levels. The general ordinance in effect tells us that in the view of the local community, legitimate disputes may be sparked by development changes that breach a statcd threshold--and these disputes must be mediated. Thus, the gcneral ordinance acts as an assertion of jurisdiction to mediate development disputes.

The piecemeal change is the actual subjcct of mediation: in acting on an applieation for, say, a variance or rezoning, the governmental body is considering a concrete use that breaches the "disputatiousness" threshold, and it may therefore attempt to mediate disputes that arise. The piecemeal change thus in a sense actualizes a land regulation, whereas the general regulation is 
changes are treated as mediations, their "dealing" aspects are not an undesirable aberration but natural parts of the dispute resolution. In keeping with the open norms of mediation, an appropriate solution is not always a smgle answer complying with fixed standards, but rather a mix of accommodations. ${ }^{248}$ Examples of these wide-ranging accommodations abound in modern land use practice. A community might ask a developer to provide park space as a tradeoff for permission to build a new development, ${ }^{249}$ or to preserve a familiar commumity landmark in exchange for permission to build at a higher density; ${ }^{250}$ or the tenants of a low income area, through the local government as mediator, may negotiate with a highrise developer for low-imcome housing to offset the loss of mexpensive residential hotel space. ${ }^{251}$ Some of these tradeoffs are controversial, and I will discuss some tests of their carefulness and fairness below. But they are at least comprehensible as mediated accommodations.

To be sure, as Lon Fuller has argued, government mediation differs from the usual form: the government mediator has the authority

merely potential; the tract zoned for "rural residential" use, for example, is usually in a threshold category that may change the future, but if the tract were rezoned to Planned Unit Development on the urging of a developer, the new zoning would in effect act as an imprimatur on an actual long term use of the land. See, e.g., MacDonald v. Board of County Comm'rs, 238 Md. 549, 210 A.2d 325 (1965). Because such a change in status usually precedes an actual development, it is unlikely to include more than a fraction of a locality's land space or population. The characteristic sign of the piecemeal change, however, is neither the size of the development nor the numbers of persons involved, see supra notes 145-54 and accompanying text, but rather the anticipation of actual development-and this development is at a potentially disputatious level. As in nuisance law, it is the change to an acutal development or actual use that can precipitate a land dispute. See Epstein, Nuisance Law: Corrective Justice and its Utilitarian Constraints, $8 \mathrm{~J}$. LEGAI STUD. 49, $72-73$ (1979).

Some of the plan jurisprudence cases and commentaries have recognized that the pieceneal change is in effect a license for actual use. See Kropf v. City of Sterling Heights, 391 Mich. 139, 171, 215 N.W.2d 179, 193 (1974) (Levin, J., concurring); Kelly, Comment on Margolis, Wright and Yanz, LAND Use L. \& ZoNing DIG., Mar. 1982, at 14. There is also an implicit recognition of the "threshold" or jurisdictional character of general zoning ordinances in some of the litigation on takings. See infra notes 299-305 and accompanying text. In this litigation courts have insisted that disputants actually apply for development permission before a takings claim can ripen. See, e.g., Agins v. City of Tiburon, 447 U.S. 255 (1980).

The courts' remand for local mediation resembles in some respects modern African courts' support of local tribal mediation and negotiation processes. Sce Center, Dispute Settlement and Dispute Processing in Zambia, in The Disputing Process-LAw IN TEN Societies, supra note 236 , at 277.

248. P. Gulliver, supra note 236, at 52-54, 58-59, 190-94; Gulliver, supra note 239, at 6-10; Susskind \& Weinstein, supra note 237, at 321, 333.

249. See, e.g., Associated Home Builders of the Greater East Bay, Inc. v. City of Walnut Creek, 4 Cal. 3d 633, 484 P.2d 606, 94 Cal. Rptr. 630 (en banc), appeal dismissed, 404 U.S. 878 (1971).

250. Kilduff, Alcazar Theater to Fall, San Francisco Chron., July 9, 1982, at 4, col. 2.

251. Id.; telephone interview with S. Colm, San Francisco North of Market Planning Coalition (June 14, 1982). 
to impose a solution, ${ }^{252}$ and thus would seem free to favor one side over another. But this may not make a great deal of difference in practice. As Melvim Eisenberg points out, even the mediator with a direct interest in the outcome is expected to hear all parties and come to an acceptable compromise. ${ }^{253}$

The government mediator has a stake in reaching an accommodation acceptable to all (thus retaining what Hirschman might call the "loyalty" of all disputants), and in avoiding both the pain and cost of overparticipation and the exit of valuable developers and/or community inenibers. ${ }^{254}$ Fuller himself, although he stresses the nondeciding role of the nuediator generally, ${ }^{255}$ discussed a local official's adjustinent of property rights in water as a process involving a "consultative" forns of governmental decisionnraking, indistinguishable from inediation in many respects, ${ }^{256}$ and departing from the Austinian concept of law as the exercise of authority. ${ }^{257}$

At the sanie time, the local government's ultimate position of authority does inake a difference: some niediations fail to reach

252. Felstiner, Influences, supra note 237, at 69; Fuller, supra note 237, at 314-15.

253. Eisenberg cites as examples the insurance adjuster who mediates claims against his employer and the architect who mediates disputes between clients and construction contractors. Eisenberg, supra note 237, at 662-64.

254. On the costs of voice, see A. Hirschman, supra note 23, at 38-40. For an example of the use of exit by an outsider, see Adans, Hilton Kills Plans for Hotel Tower in Tenderloin, San Francisco Exam., May 17, 1981, § B, at 1, col. 5 (hotel chain said it would abandon its plans in the face of what it regarded as excessive deinands by city and neighborhood residents for low incoine housing).

Ellickson, supra note 4, at 436-38, is particularly concerned that persons without great pohitical influence, including outsiders, be protected against unfair demands by localities. The present analysis suggests that the possibility of exit (going to a competing community) gives considerable leverage to outsiders, including those that might not normally be thought particularly desirable. See, e.g., Morganthaler, To Keep Their Town Alive, the Residents of Naturita, Colo., Want a Nuclear Dump, Wall St. J., July 1, 1982, at 19, col. 4; Minsky, In Depressed Midwest, Two Small Towns Fight for a Smelly Hog-Slaughtering Plant, Wall St. J., Feb. 3, 1982, at 27, col. 4. The outsiders who need protection are those for whoin exit gives no leverageparticularly low incoine groups. Perhaps for this reason low incoine groups have been the object of special attention in statutory and judicial injection of regional duties into local land regulation. See infra note 260. Ellickson's analysis also suggests that exit options in lousing can be prevented by a hoineowners' inonopoly over residential space. See Ellickson, supra note 4, at 425-30. An effective hoineowners' cartel, however, seeins rather unlikely because many persons and communities would liave to act in concert. See Wolfram, The Sale of Development Rights and Zoning in the Preservation of Open Space: Lindahl Equilibrium and a Case Study, 57 LAND EcoN. 398, 406 (1981).

255. Fuller, supra note 237 , at $308,314-15$.

256. Id. at 334-36. See also Danzig \& Lowy, supra note 237, at $682-83$ (the mediating function of nominally authoritative regulatory agencies). Fuller, supra note 237, at 337, remarks that the consultative aspects of the watermaster's duties are analogous to what social scientists might call "primitive" social ordering, again suggesting that local governmental mediation processes reflect a far more ancient mode of governance than does The Federalist's intricate overlapping of checks and balances.

257. Fuller, supra note 237, at 339. 
accommodation, and if that happens a governmental body must act authoritatively, without securing the assent of all interested parties, and leaving some party to "lump it."258 It is the failed mediation that appears in the courts, when some party is dissatisfied, and that necessitates a jurisprudence of mediation, to probe the care and fairness of the process. How, then, are the courts to assess the reasonableness of a failed inediation of a piecemeal change? When should the results be left undisturbed, and a party left dissatisfied? Conversely, when should the mediation results be overturned? These are the issues for a mediative jurisprudence, which I address in Part IV.

\section{IV}

\section{An Alternative Jurisprudence: Piecemeal Changes As MEDiation}

Local land regulations, including piecemeal changes, must all meet a variety of substantive requirements in federal and state law. Thus they must not violate first amendment rights, ${ }^{259}$ they must provide due process, and they must counply with legislative or judicial mandates to take on regional responsibilities, particularly those of helping to care for low income needs. ${ }^{260}$ But one lesson froin plan jurisprudence is that even when these larger requirements are met, locally determined piecemeal changes may still be ill-considered or unfair, and the courts cannot rely on a traditional notion of legislative "reasonableness," or on Federalist arguments for institutional competence. Although this Article rejects the adjudicative model adopted by plan jurisprudence, it shares plan jurisprudence's goal: a mediation model too should strive to assure fairness and due consideration.

The terms "fairness" and "due consideration" both take meaning from the context in which they arise. We have seen that in a large legislature these qualities result from a clash of interests leading to temporary stasis. In local piecemeal changes, the meaning of fairness and due consideration should arise from the elements that legitimize local government. From the alternate tradition in American pohtical thinking, we may identify those elements as participation and withdrawalor, in Hirschman's terms, the combination of voice and exit. These elements should guide a jurisprudence of local inediations toward the

258. Felstiner, Influences, supra note 237, at 81. See also The Disputing Process-LAw IN TEN SOCIETIES, supra note 236, at 9 (distinguishing Felstiner's "lumping it" froin Hirschinan's "exit").

259. E.g., Metromedia, Inc. v. City of San Diego, 453 U.S. 490 (1981).

260. See, e.g., Southern Burlington County NAACP v. Township of Mt. Laurel, 67 N.J. 151, 336 A.2d 713, appeal dismissed and cert. denied, 423 U.S. 808 (1975); Berenson v. Town of New Castle, 67 A.D.2d 506, 415 N.Y.S.2d 669 (1979); CAL. Gov'T CODE $\$ \S 65580-65589$ (West Supp. 1983). 
goals of fairness and due consideration. In this Part, I will develop a concept of due consideration that depends on participation or voice, and a concept of fairness that depends on the possibility of exit. In outlining these concepts I will draw on ideas and comparisons from plan jurisprudence, but will also look to some recent reform proposals in land use regulation, especially those stemming from environmental impact review and from economic analysis.

\section{A. Due Consideration as Voice}

Plan jurisprudence abandons the legislative clash of interests as a guarantor of due consideration, and instead sets forth two questions for assessing whether a given pieceineal change was adequately considered. First, it asks whether the change process followed the deliberative processes of a court or quasi-court; second, whether the change follows from an earlier deliberative process, that is, from the previously adopted "general plan." A mediation inodel, unlike plan jurisprudence, attempts to assure due consideration through a pattern of voice-through hearing from interested parties and atteinpting to arrive at an accommodation acceptable to thein within the framework of larger community norms.

As a number of commentators have noted, unediation has its own rlyythen for working out accommodations, ${ }^{261}$ and a court should ask if the inediation sequence has been followed when it tests whetler a result was duly considered-whether imterested parties had enough opportunity to partieipate. ${ }^{262}$ At least three basic stages can be delineated: (1) identification of disputants; (2) exploration of issues; and (3) explanation of outcoine.

In plan jurisprudence the stages appear as notice, hearings, and findings; and while these suggest too close an adherence to a judicial prototype, a nuediative jursiprudence can use and flesh out that prototype. But it can also use other modern planning ideas, notably environinental impact analysis.

\section{Identification of Disputants and Sources of Dispute}

Disputes over proposed land use clianges may not be immediately obvious, and failure to inquire into latent disputes and to locate potential disputants nuay abort the accommodation that mediation slould

261. P. Gulliver, supra note 236, at 121-77; Susskind \& Weinstein, supra note 237, at 337-45 (identifying nine steps in the process of environmental mediation).

262. Gulliver notes that professional mediators are conscious that negotiations may break down when the stages of negotiation are rushed (e.g., union negotiators think a precipitate wage offer is a trick), and refers to these stages as negotiative due process. P. Gulliver, supra note 236, at 175-76. 
create. ${ }^{263}$ One way to bring out latent disputes is notice to persons possibly interested in the change. Indeed, the persons who receive notice are those perceived by the community to have some stake in the piecemeal change. Plan jurisprudence itself grew out of, inter alia, the older variance proceedings, where soine objectors had too little opportunity to voice objections, particularly if local boards ignored notice and hearmg requirements. ${ }^{264}$ Current enabling statutes and local ordmances require that piecemeal changes proceed only after notice to interested groups, and after some hearing to allow them to object. ${ }^{265}$ Courts have quite rightly taken these requirements extremely seriously, however discomforting they may be. ${ }^{266}$

A mediation model suggests that when notice is given and no objections are raised, the courts have little reason to second-guess a local board's approval of a piecemeal change, and indeed the presumption should favor the proposed change. ${ }^{267}$ If one of the functions of a jurisprudence of piecemeal changes is to assure "voice" in the sense of a considered accommodation of differences, in the absence of differences one seeking change should be able to go forward.

There may, however, be some circumstances in which lack of objection is not a rehable indicator of general consent. At times many parties may have an interest, but the interest of any individual may be weak. ${ }^{268}$ Land developments whose effects are cunnulative or most likely to be felt in the future often fail to arouse objections strong

263. Susskind \& Weinstein, supra note 237 , at 320.

264. See supra note 76 and accompanying text.

265. See, e.g., KY. Rev. STAT. $§ 100.214$ (Supp. 1978) (zoning change must give notice to adjacent owners and those across the street). See also Horn v. County of Ventura, 24 Cal. 3d 605, 616-18, 596 P.2d 1134, 1140-41, 156 Cal. Rptr. 718, 724-25 (1979) (due process requires notice to those who may suffer "significant" deprivation of property from land use change). $C f$. N.J. STAT. ANN. § 40:55D-63 (West Supp. 1982-83) (amendment protested by $20 \%$ of surrounding owners nust be passed by $2 / 3$ supermajority).

266. See, e.g., Grotto v. Little Friends, Inc., 104 11l. App. 3d 105, 432 N.E.2d 634 (1982) (failure to comply with ordinance's notice requirements deprived board of jurisdiction and nullified grant of variance or special use permit for a holne for autistic children). See also Barrie v. Kitsap County, 84 Wash. 2d 579, 584-86, 527 P.2d 1377, 1381 (1974) (rezoning invalid since notice misled readers into thinking rezone was only for purpose of a proposed PUD which was voided by trial court due to inadequate notice of hearing).

267. See, e.g., Town of Somerset v. County Council, 229 Md. 42, 50, 181 A.2d 671, 675-76 (1962) (absence of complamt from neighbors dcemed relevant in making exception from Maryland's "change/mistake" rule). For a discussion of Maryland's change/mistake rule, see supra note 44. Older variance boards apparently also took into account the presence or absence of objections from neighbors. See supra note 82. Developers continue to atteinpt to show through polls the abseuce of neighborhood objections, and to line up neighborhood supporters. See, e.g., Kilduff, Condominiums at Winterland OXd, San Francisco Chron., Dec. 12, 1981, at 17, col. 5.

268. For an analysis of this situation as a more general political problem, see M. OLson, supra note 65 . 
enough to raise the full range of potential disputes. ${ }^{269}$ Preexisting plans and studies may reveal such objections, as well as others that absent disputants inight raise.

Modern impact analysis suggests another inethod for raismg potential disputes. In California and elsewhere, the courts have held that land use change permits are "government projects" effectively requiring soine impact review of all discretionary grants of private proposals. ${ }^{270}$ Although such rulings have been criticized as extending too far the idea of "government project,"271 they make inore sense where the procedures for regulatory change take the forn 1 of inediated negotiations of disputes. Threshold environmental review (i.e., the deternination whether some proposed change will have a significant impact) inquires into potential objections when simple notice will fail to disclose or deal with them. As the courts have recognized, failure to identify those objections can short circuit the impact review process-just as it can hamper inediation. ${ }^{272}$

\section{Exploration of Issues}

Plan jurisprudence rightly recognizes that small-scale land changes require a forum and a process for confronting factual and normative issues. Quasi-judicial proceedings, however, provide too limited a range within which the parties can exchange imformation. The literature of negotiation and inediation suggests that the confrontation of issues may take inuch inore varied and vivid forms than can be encompassed by judicial proceedings. At the outset, for example, the parties may engage in posturing and name-calling behavior that delineates the outer extreines of their respective positions. ${ }^{273}$ This is an expression of voice certainly familiar in the annals of pieceineal land changes. ${ }^{274}$

269. See Susskind \& Weinstein, supra note 237, at 330-33 (noting that the diffuse character of environmental harms inakes identification of parties inore difficult).

270. Friends of Mammoth v. Board of Supervisors, 8 Cal. 3d 247, 502 P.2d 1049, 104 Cal. Rptr. 761 (1972). See also Cook v. Clallam County, 27 Wash. App. 410,618 P.2d 1030 (1980). By the late 1970's, nimeteen states had state versions of environmental impact review, with soine application to local land regulation. See 1977 U.S. Council on ENvtl. QualitY ANN. REP. 13035; see also Pearlman, State Environmental Policy Acts: Local Decision Making and Land Use Planning, 43 J. InST. AM. PlanNers 42, 43, 47 (1977).

271. Hagman, supra note 14 , at 47 . Hagman also criticizes environmental review for diverging from the theory behind preplanning, id. at $47-49$, but appears to view ad hoc regulation as preferable to preplanning, id. at 50 .

272. See, e.g., Barrie v. Kitsap County, 93 Wash. 2d 843, 613 P.2d 1148 (1980) (EIS invalid for failure to set forth opposing points of view on social and economic environmental effects).

273. P. Gulliver, supra note 236 , at $135-41$.

274. The recent conflict over the massive Portman hotel project on Broadway is a reininder of the einotionally charged theatrics that can accoinpany individual development disputes. See Kakutani, Portman Hotel: Broadway is a House Divided, N.Y. Times, Jan. 24, 1982, § 2, at 1, col. 3. 
In the later stages of negotiation the parties may construct "bids" or packages of solutions. ${ }^{275}$ These confrontations and explorations assist a successful, mutually acceptable solution; but they are certainly not suitable for a courtlike process of direct and cross-examination.

Other planning and regulatory processes, however, further the exchange of information. Hearings, for example, are a standard requireinent in many land use changes. And here too, environmental impact review may be extremely helpful $\mathrm{m}$ airing issues. The stated purposes of these reviews, aside from the substantive goal of preserving the nebulously defined "environment," are essentially procedural: to publicize issues, to draw in interested parties, to examine alternative solutions, and to satisfy the public that the issues have been fully explored. ${ }^{276}$ Just as important, they give interested persons a sense of participation in the decision, either personally or through the auspices of likeminded others.

In a larger sense, voice im the forn of environmental review exemplifies what Richard Stewart calls "interest representation."277 Interest representation proposals norinally attempt to counteract the "capture" of the regulators by the regulated interest; 278 in the land use area, "capture" argnments usually refer to the undue influence on the local government that developers and real estate interests may exercise to the exclusion of other interested citizens, ${ }^{279}$ although the developers may regard the local council as the "captive" of an implacably antidevelopment majority. ${ }^{280}$

Interest representation and particularly impact review have been criticized for merely transposing "capture" from the regulated interests to other partisan and self-appointed "public interest" groups, ${ }^{281}$ and for

275. P. Gulliver, supra note 236, at 147-48; Gulliver, supra note 239, at 13-14. Such bids or packages are also familiar in the land use area. In the Portman project imbroglio, for example, opponents of the project came up with an alternative design that might save some old theaters. See Kakutani, supra note 274.

276. See, e.g., No Oil, Inc. v. City of Los Angeles, 13 Cal. 3d 68, 529 P.2d 66, 118 Cal. Rptr. 34 (1974). For the "essentially procedural" language, see Vermont Yankee Nuclear Power Corp. v. Natural Resources Defense Council, 435 U.S. 519, 558 (1978).

277. Stewart, supra note 16 , at 1760 .

278. Id. at 1682-83, 1713; see also Sabatier, supra note 130, at 302-06.

279. See, e.g., Chrobuck v. Snohomish County, 78 Wash. 2d 858, 480 P.2d 489 (1971).

280. See, e.g., Marmah, Inc. v. Town of Greenwich, 176 Conn. 116, 405 A.2d 63 (1978).

281. Stewart, supra note 16, at 1763-64. Henderson and Pearson raise a related objection to environmental impact review-that it is an effort to appropriate expert skills for goals to which the experts may be opposed. Henderson \& Pearson, Implementing Federal Environmental Policies: The Limits of Aspirational Commands, 78 ColuM. L. REv. 1429, 1456-62 (1978). The reluctant expert has a motive to act evenhandedly, however, in a mediation context in which the participants can threaten exit or voice. For analogous controls on a nonimpartial judge, see Verkuil, supra note 144 , at $788-89$. 
causing delay and expense that verges on deadlock. ${ }^{282}$ But in a local setting the probleins of incompleteness and paralysis inay be less significant than they are for the "extended republic" and its vast bureaucracy. ${ }^{283}$ "Capture" itself may be less threatening in local mediation where even partisan authorities can be restrained by the threats of voice and exit - that is, the threats that the disputants may either pack the hearing room, or pull their business out of town altogether. ${ }^{284}$ Then too, the local community's sinaller size narrows the range of interest groups that may intervene, thus leaving less opportumity for domination by the self-appointed guardians, or for the interminable delay and expense that accompany an effort to hear too inany poimts of view.

In any event, some delay inay well be useful to a local decision. For one thing, it prevents rash decisions about land uses-decisions whose consequences will last a long time. In a sense, the delay is like that which accoinpanies a clash of imterests in a larger legislature: both prevent hasty decisions that might overlook a larger common good.

Moreover, the seemingly wasteful noise and repetition of impact review may have other uses. Patient collection of views, even if they are repetitious, serves a "venting" function that ultimately helps the disputants to accept a decision. ${ }^{285}$ While law-and-economics critiques rightly poimt out that the costs of process may outweigh the benefits in results, ${ }^{286}$ a lack of voice also carries real costs, however difficult they inay be to quantify. Information leading to more lasting or indeed more efficient accommodations may be lost; ${ }^{287}$ and lacking a way to measure the relative costs of environinental effects, ${ }^{288}$ we may depend primarily on voice to keep us informed of costs and benefits. Then too, without voice, those defeated in final resolution may begrudge the short shrift they received and may be lost to useful civic participation in the future. ${ }^{289}$ On a less ideahstic note, disgruntled losers inay also litigate-at costs even higher than those of mediation. ${ }^{290}$

A mediation model thus puts interest representation proposals to

282. Stewart, supra note 16 , at 1770 .

283. On the impact of interest group fragmentation at the federal level, see D. WALKER, supra note 57 , at $227-46$.

284. See supra notes $253-54$ \& 281.

285. For an older suggestion of this "venting" function ("catharsis") in extended public hearings on land use issues, see Goldston \& Scheuer, supra note 76, at 255. See also C. PERIN, EvERYTHING IN ITS PLACE 183-84 (1977). But see L. LAKE, ENVIRONMENTAL. REgulation 69-71 (1982).

286. Ellickson, supra note 16, at 699; Kmiec, Deregulation, supra note 15, at 46-49.

287. A. HiRschman, supra note 23, at 26; Danzig \& Lowy, supra note 237, at 679.

288. Sagoff, Economic Theory and Environmental Law, 79 MiCH. L. REV. 1393, 1402-10 (1981); see also Pear, Fiscal Plans Bear the Telltale Signs of Cost Benefit Analysis, N.Y. Times, Feb. $14,1982, \S 4$, at 2 , col. 1 (criticizing the manipulability of cost-benefit analysis in "pricing" environmental costs).

289. Danzig \& Lowy, supra note 237 , at $678-81$.

290. Susskind \& Weinstem, supra note 237 , at 315-16. 
good use at the local level, employmg them to make voice effective. These proposals suggest the value of voice in mediation: These techniques expand issues and give time for a range of arguments and explorations of the dispute, even when those explorations are emotionally charged. Standard planning devices too can give evidence of efforts to expand issues-the hearings, the reports and so on. But again, we should not be misled (as some courts have been) by a jurisprudence that fixes merely on the formal presence of a plan and plan consistency; forinal devices may impede an exploration of issues rather than assure it. ${ }^{291}$

\section{Explanation}

Plan jurisprudence calls for standards and records showing in specific form two general features common to dispute resolution methods: first, the resolution should be based on norins; and second, some disclosure must be made of the relationship between the relevant norms and the actual conclusion.

Plan jurisprudence, however, suggests that a record should contain only matters relevant to fixed preexisting standards rather than the free-form discussions in land changes, in which disputants refer to a wide variety of pohicy considerations and to tradeoffs among them. Moreover, if the "standard" is a vague or inconsistent plan, a mere reference to it may conceal rather than disclose the normative bases for a specific decision. ${ }^{292}$

A mediation inodel of land changes recognizes the need for explanation, and suggests a different approach to norinative disclosure. Acknowledging that not all norins can be satisfied at once, and that some may have to be weighed against others, a mediative approach would require that norms and tradeoffs be disclosed and explained case-bycase. Some standard planning techniques encourage a local body to do this. Findings may help. Impact analysis is especially appropriate for such disclosure, since it involves not only an issue-expanding review process, ${ }^{293}$ but also an ultimate explanation of norms and tradeoffs in an impact statement.

Explanation furthers due consideration in two ways. First, it reinforces and encourages an exploration of issues and potential accommo-

291. See supra notes 161-66 and accompanying text.

292. In a recent dispute in San Francisco, for example, the neighbors' opposition to a proposed five-house development centered on the uprooting of a redwood grove. The planning board, after much vacillation about the fate of the trees, rejected the proposal on the ground that it did not conform to the city's master plan -at best an opaque "explanation" and one that has little to do with the main issue in the dispute. Hou, Developer Loses To the Neighbors in Pacific Heights, San Francisco Chron., Oct. 9, 1981, at 32, col. 1.

293. See supra note 276 and accompanying text. 
dations; the very fact that decisionmakers have to explain outcoines may encourage them to think of alternatives and mitigations. ${ }^{294} \mathrm{Sec}-$ ond, explanation ultimately helps to reconcile the parties. Some persons in a mediation may lose in whole or $\mathrm{m}$ part-developers may have to put shrubs around the shopping center; the neighbors may have to put up with the shopping center itself. But they all may be at least partially mollified if they know the reasons; like the opportunity for "venting," explanation treats seriously the objections of those who ultimately have to acquiesce in the outcome. ${ }^{295}$

In sum, in imquiring whether a piecemeal land change was duly considered, a court should focus on voice in niediation and ask whether the local body went through the steps of identifying disputants, exploring issues, and explaining results. But doubts about piecenneal changes do not concern only due consideration or voice. Even when a local body goes through the steps of voice we may still think that the result is unfair to an imdividual. In the next Section, I turn to the meaning of fairness im local mediation.

\section{B. Fairness and Exit}

What does it mean to say that a governmental body has acted fairly? Clearly, fairness means different things in different contexts.

In a large legislative body, fairness means partial satisfaction through coatition-building; over time, all parties may participate in a

294. See Citizens Ass'n v. Zoning Comm'n, 477 F.2d 402, 408 (D.C. Cir. 1973); see also Verkuil, supra note 144 , at 791.

295. Felstiner, Influences, supra note 237 , at 81 . These functions of explanation help to clarify one of the perennial difficulties with piecemeal changes through referendum. Courts ruling against these popular votes have generally cited a variety of lapses in plebiscitary decisionmaking. mcluding both lapses of exploration (e.g., the public's inability to hold hearings and go through reports) and explanation (e.g., the public's inability to inake records and findings). See supra notes 110-11 \& 119-22. On the other liand, courts upholding such plebiscites have adverted by and large only to matters of exploration: the highly public debate over the issues, and the opportunity of all parties to persuade the voters. See, e.g., Arnel Dev. Co. v. City of Costa Mesa, 28 Cal. 3d 511, 524, 620 P.2d 565, 573, 169 Cal. Rptr. 904, 912 (1980); Meridian Dev. Co. v. Edison Township, 91 N.J. Super. 310, 315, 220 A.2d 121, 124 (1966), quoted in Margolis v. District Court, 638 P.2d 297, 305 (Colo. 1981).

These defenses of plebiscitary methods neglect one aspect of exploration-the packaging and testing of alternatives and compromises that are virtually impossible in popular votes-and they entirely fail to deal with the absence of explanation of the outcomc. Simce their modern inception in the mid-19th century, plebiscites have been notably blank as to normative disclosure; the yesor-no vote nay be based on one or more of a number of considerations, and not knowing which was decisive only fceds fears that improper motives lay behind a vote. See, e.g., Sager, supra note 119 , at 1411-15. The lapses of exploration and explanation point to a more fundamental problem in plebiscitary methods: these decisions, as win-or-lose determinations, are more comparable to judicial decisions than to either mediation or legislation, and therefore mediative voice nust fail. One cannot completely rule out the possibility of an adequately explored or explaimed plebiscitory decision on a piecemeal land clange, but the presumption would be against such decisions in a niediation model. 
majority, and satisfy at least some of their desires. ${ }^{296}$ Locally, these coalition-building assurances are unreliable. But litigation and commentary about local land regulation suggest that there are some concepts of fairness here too. Concepts of fairness, for example, are apparent in charges that local actions "take" private property, or that a community is violating its own stated plan, or that its regulations would be more equitable if they copied the private market.

In sorting out these meanings and how they apply to local government, contract analysis of fairness is helpful. According to contract analysis, there are at least two aspects to fairness: fairness of result (that is, as a restraint on distribution, or more particularly on redistribution), and fairness im the bargaining arrangements (that is, as a restraint on surprise or duress). ${ }^{297}$

In the following subsections, I will discuss the various meanings of fairness in piecemeal changes from both of these contract perspectives, but will argue that of the two, the latter is more important in local land regulations. It is also more mteresting because on close analysis, the idea of fairness as "no surprise" brings us back to Hirschman's concept of exit: the party who is not surprised, and who can choose to avoid the deal, is the party who can ultimately exit.

\section{Fairness as a Distributive or Redistributive Restraint}

The use of "takings" clauses of federal and state constitutions is a major litigative vehicle for checking unfairness in local land regulation. Usually, the party raising the takings claim is the disappointed project initiator; neighbors or others opposing a development, because of their more diffuse and less direct property interests, have less frequently mounted such claims. ${ }^{298}$

The root of a takings claim is that some public act has placed on an individual or group too high a proportion of some burden-a burden which all (or at least some larger portion of the community) should

296. See supra notes $60-61$ and accompanying text.

297. Eisenberg, The Bargain Principle and Its Limits, 95 HaRv. L. Rev. 741, $752-54$ (1982); Leff, Unconscionability and the Code-the Emperor's New Clause, 115 U. PA. L. Rev. 485, 486-87 (1967). Eisenberg argues, however, that redistributive and bargaining fairness overlap. On bargaining fairness as a limit on redistribution, see Gordley, Equality in Exchange, 69 CALIF. L. REv. 1587, 1633 (1981).

298. Boilerplate land use law concedes to neighbors no vested property rights in existing zoning. See R. ANDERSON, supra note $10, \S 4.27$. While this rule is relaxed to the extent of allowing standing to neighbors to contest changes, they have no takings claim, because they have had no property rights "taken." As to project initiators, they appear to bring takings claims more frequently than the track record would suggest is appropriate, perhaps suggesting that these claims are used in part as bargaining moves to induce further negotiation. But for recent developments pointing to a sharper look at local practices under takings doctrine, see infra note 305 . 
bear. ${ }^{299}$ Takings doctrine is thus essentially a limitation on redistributions or redefinitions of property rights that harm particular individuals. Actual physical invasions of property, perhaps because these are such obvious takings, have been relatively closely reviewed. ${ }^{300}$ But physically noninvasive regulations may also "take" property, and traditional takings cases suggest that these can be justified only when they are in effect nonredistributive-e.g., when they are offset by some reciprocal benefits to the party from whom property was taken, or when the use regulated is so noxious that the party complaining of a taking never had a right to it in the first place..$^{301}$

These older tests, however, have never been strictly apphed to local land decisions. ${ }^{302}$ Moreover, the current federal formulation for cases where a noninvasive regulation is challenged as a taking-that the party be seriously disturbed in his "imvestment-backed expectations" ${ }^{203}$ and be deprived not just of some portion of his use, but of any and all "reasonable beneficial use"304_implies that local readjustments of land controls may be upheld unless their redistributive effects are egregious. ${ }^{305}$ Thus, federal takings doctrine, while it acts as some sub-

299. See, e.g., Agins v. City of Tiburon, 447 U.S. 255, 260 (1980) ("The determination that governmental action constitutes a taking is, in essence, a determination that the public at large, rather than a single owner, must bear the burden of an exercise of state power in the public interest."); Pennsylvania Coal Co. v. Mahon, 260 U.S. 393, 416 (1922) ("[T]he qucstion at bottom is upon whom the loss of the changes desired should fall."). See also Mandelker, Inverse Condemnation: The Constitutional Limils of Public Responsibility, 1966 W1S. L. REV. 3, 8. The literature on "taking" has been voluminous. See, e.g., B. ACKerman, PrIVATE PROPERTY AND THE CoNSTITUTION (1977), reviewed in Epstein, Book Review, 30 STAN. L. REv. 635 (1978); Costonis, "Fair" Compensation and the Accommodation Power: Antidotes for the Taking Impasse in Land Use Controversies, 75 Colum. L. Rev. 1021 (1975); Michelman, supra note 3; Sax, Takings, Privale Property and Public Rights, 81 YALE L.J. 149 (1971).

300. See Loretto v. Teleprompter Manhattan CATV Corp., 102 S. Ct. 3164 (1982); see also Kaiser Aetna v. United States, 444 U.S. 164 (1979); Michelman, supra note 3, at 1228, 1233.

301. See Penn Cent. Transp. Co. v. New York City, 438 U.S. 104, 138 (1978) (Rehnquist, J., dissenting).

302. See, e.g., Penn Cent. Transp. Co. v. New York City, 438 U.S. 104 (1978); Goldblatt v.' Town of Hempstead, 369 U.S. 590 (1962); Miller v. Schoene, 276 U.S. 272 (1928); Maher v. City of New Orleans, 516 F.2d 1051 (5th Cir. 1975), cert. denied, 426 U.S. 905 (1976); Just v. Marinette County, 56 Wis. 2d 7, 201 N.W.2d 761 (1972).

303. Agins v. City of Tiburon, 447 U.S. 255, 262-63 (1980); Penn Cent. Transp. Co. v. New York City, 438 U.S. 104, 127, 136 (1978); see also PruneYard Shopping Center v. Robins, 447 U.S. 74, 83-84 (1980); Michelman, supra note 3, at 1233.

304. Penn Cent. Transp. Co. v. New York City, 438 U.S. 104, 138 (1978); see also Agins v. City of Tiburon, 447 U.S. 255, 262 (1980).

305. In Agims v. City of Tiburon, 24 Cal. 3d 266, 277, 598 P.2d 25, 31, 157 Cal. Rptr. 372, 378 (1979) (en banc), affd, 447 U.S. 255 (1980), the California Supreme Court appeared to define a taking as an action that deprived the landowner of "substantially all reasonable use of his property." The United States Supreme Court, however, has given some signals that in the future it may look more critically at the distributive effect of local regulations, either as takings, see, e.g., San Diego Gas \& Elec. Co. v. City of San Diego, 450 U.S. 621, $651-53$ (1981) (Brennan, J., dissenting); see also Devines v. Maier, 665 F.2d 138 (7th Cir. 1981), or as violations of antitrust law, see Community Communications Co. v. City of Boulder, 455 U.S. 40 (1982). The effect of these more 
stantive check on the fairness of local land decisions, sets a very wide horizon within which those decisions can adjust property claims.

The neighbors' counterpart to a takings claim appeals to the locality's plan. This appeal to locally defined standards has traditionally come not from the proponent of change, but from the neighbors who opposed some deal that was in fact struck. Indeed, it was precisely these neighbors' claims that there should be some "public interest" test of variances and zoning changes that led the courts to the plan jurisprudence, and that brought the courts to see the locality's own plan as a substantive standard against which to measure the individual bargain. ${ }^{306}$ I have recounted at length the difficulties of relying on the advance plan; most rclevant here are the facts that the plan itself may be vague or unfairly redistributive. ${ }^{307}$ Thus, a "general plan" is a highly dubious limitation on unfair redistribution.

In sum, given the way these doctrines have developed, the antiredistributive concept of fairness provides only very loose checks on local government discretion. Takings claims leave very wide latitude to the locality; and local general plans are too easily manipulable to act as serious limitations.

But plan jurisprudence does direct our attention to a second perspective on fairness. In holding that land changes should be based on some earkier defined local standards, plan jurisprudence uses predictability, or protection froin surprise, as anothcr criterion of fairness.

A somewhat similar inovement-froin fairness as a substantive check on redistribution to fairness as largely procedural predictability-emerges from the economic analysis in soine of the academic land use reform proposals. The next subsection focuses on these proposals.

\section{From Redistributive Fairness to Predictability: Lessons from the Market-Mimicking Model}

Market-1nimicking proposals generally take the position that land regulation outcoines should as closely as possible track the decisions that, but for "market failure," would be inade through private transactions. ${ }^{308}$ The chief object of these proposals is to maintain (or restore)

stringent tests on land controls is as yet uncertain. Compare, e.g., Mason City Center Assocs. v. City of Mason City, 468 F. Supp. 737 (N.D. lowa 1979) (no state-action antitrust immunity for city), aff d, 671 F.2d 1146 (8th Cir. 1982), with Westborough Mall, Inc. v. City of Cape Girardeau, 532 F. Supp. 284 (E.D. Mo. 1981) (immunity extended to city).

306. Krasnowiecki, Planned Unit Development, supra note 104, at 73-77.

307. See supra notes $153-54$ and accompanying text. For a plan involving very substantial reduction in uses available to the owner, see San Diego Gas \& Elec. Co. v. City of San Diego, 450 U.S. 621 (1981).

308. For a general discussion of market-mimicking proposals, see Stewart, supra note 16, at 1702-11. 
the efficient allocation of goods normally associated with market transactions, and many proponents take a skeptical stance toward expansive dispute settlement procedures, believing that these could be so costly as to produce inefficient net results. ${ }^{309}$

But market-mimicking inodels nevertheless do have some surprising similarities to a mediation inodel. Their stress on exchange suggests that the land use change inay encoinpass various types of quid pro quo, and thus implies that disputes may be settled with different packages of accommodations, rather than through the all-or-nothing outcoine reached by a court applying a given standard. More important for present purposes, market proposals have some important lessons about the meaning of fairness in inaking pieceineal changes. Although these proposals appear to treat fairness as a brake on redistribution, on closer analysis their concept of fairness is protection froin surprise.

At first glance, inarket-mimicking proposals seem to deal with fairness, if at all, as a substantive limitation on redistribution. ${ }^{310}$ This is because inarket transactions-the model to be einulated-involve trading rather than sheer wealth transfer. In economic models, therefore, regulations require us where possible to pay for what we want rather than allowing us simply to take it from others. For exainple, Robert Ellickson has suggested that piecemeal changes be regulated by an expanded version of traditional nuisance law; his proposed local "nuisance boards" would provide a public forum for working out private control of the adverse "spillover" effects of individual land uses. As in market transactions, individuals would be required to signal their preferences and pay accordingly. ${ }^{311}$ Other scholars have formulated land regulations that would act as a different kind of market substitute: regulations would serve as brokerage devices, to charge and compensate for the otherwise unadjusted "wipeouts" and "windfalls" that so often accoinpany land developinent. ${ }^{312}$

309. Kmiec thinks that the greatest efficiency gains in his own reform proposal come froin procedural simplification, whereby neighbors are precluded from participation in individual land decisions. Kmiec, Deregulation, supra note 15, at 83, 129. See also Ellickson, supra note 16, at 697-99; Huffman \& Plantico, Toward a Theory of Land Use Planning: Lessons from Oregon, 14 LAND \& WATER L. REV. 1 (1979) (criticizing Oregon's land planning scheme).

310. See, e.g., Ellickson, supra note 16, at 699 . However, an efficient regulation in the Kaldor-Hicks sense (benefits to "gainer" exceed costs to "losers") need not be fair in a distributional sense, since an individual could lose a great deal even if his costs were outweighed by the pubhc's benefits. Pareto efficiency, by contrast, finds a situation efficient if no one can be made better off unless someone elsc is inade worse off. For an exposition of these concepts of efficiency, see R. ElLICKSON \& D. TARLOCK, supra note 6, at 63-64. For possible divergences between distributional faimess and efficiency, see Michelman, supra note 3, at 1234-35; Weisbrod, supra note 3, at 11 .

311. Ellickson; supra note 16.

312. See generally D. Hagman \& D. Misczynski, WindFalls For WipEouts (1978). $\mathrm{Kmiec}$ also develops a land use reform proposal based on value recapture. See Kmiec, Deregula- 
Municipahties have begun to apply market-1nimicking theory in their own ways, arguimg that various new developments have external costs to the public, and that fairness requires that these costs should be offset by "amenities" or charges imposed on the new development to benefit the existing community. ${ }^{313}$ Thus, soine San Francisco officials, for example, hope to require new office developers to build housing and perhaps even to pay transportation fees for the office workers attracted to new office structures, or to provide art work and mimi-parks to compensate for the shadows and gloon their structures will create. $^{314}$ In variations on this theine, sone nunicipalities have "paid" land owners for the mamtenance of uneconomic historic structures or open spaces, or for the development of low incone housing, by permitting these owners to exceed bulk limitations on their other properties. $^{315}$

City governments find such devices attractive because they may eliminate or reduce their own expenditures for public anienities; but developers have greeted such devices with outrage. ${ }^{316}$ This reaction should at least suggest that fairness problems in local land use decisions are not completely solved by using the market-mimicking approach.

First, nuarket models nuay neglect considerations of fairness altogether, smce they nuay seek only efficient solutions. An efficient regula-

tion, supra note 15, at 115-29. See also Baker, Recovering Privately and Publicly Conferred Windfalls-An Exploratory Essay, 13 URB. LAw. vii (1981); Note, Efficient Land Use and the Internalization of Beneficial Spillovers: An Economic and Legal Analysis, 31 STAN. L. Rev. 457 (1979).

313. See, e.g., Associated Homebuilders of the Greater East Bay, Inc. v. City of Walnut Creek, 4 Cal. 3d 633, 484 P.2d 606, 94 Cal. Rptr. 630, appeal dismissed, 404 U.S. 878 (1971); Westfield-Palos Verdes Co. v. City of Rancho Palos Verdes, 73 Cal. App. 3d 486, 141 Cal. Rptr. 36 (1977); City of Dunedin v. Contractors \& Builders Ass'n, 312 So. $2 d 763$ (Fla. Dist. Ct. App. 1975), rev'd on other grounds, 329 So. $2 \mathrm{~d} 314$ (1976) ; Board of Educ. v. Surety Developers, Inc., 63 Ill. 2d 193, 347 N.E.2d 149 (1975). But sce West Park Ave., Inc. v. Township of Ocean, 48 N.J. 122, 224 A.2d 1 (1966). For a critical view of such charges, see Ellickson, supra note 4.

314. Kilduff, Hearing Today on Muni Tax, San Francisco Chron., Mar. 15, 1982, at 4, col. 1. For other amenities that may be required of downtown builders, see Hsu, Firm Gives Money for S.F. Housing, San Francisco Chron., Nov. 25, 1981, at 7, col. 4; Kilduff, How Planners Get Housing From Highrises, San Francisco Chron., Apr. 10, 1981, at 7, col. 1; Kilduff, Alcazar Theater to Fall, San Francisco Chron., July 9, 1982, at 4, col. 2 (condoninium project approved after developer negotiated with local low income groups, agreed to retain historic theater facade, fund some low incone housing, and provide funds for neighborhood theater programs). For similar plans in New York, see Horsley, Radical Midtown Zoning Overhaul, N.Y. Times, July 13, 1980, \& 1, at 1, col. 1. For San Francisco's earlier versions of "bonus zoning," see N. Marcus \& M. Groves, THE NeW ZoNing 139 (1970).

315. See, e.g., Costonis, Devclopment Rights Transfer: An Exploratory Essay, 83 YALE L.J. 75 (1973); Danels \& Magida, Application of Transfer of Development Rights to Inner City Communities: A Proposed Municipal Land Use Rights Act, 11 URB. LAw. 124 (1979); Ellickson, supra note 15, at 1180-81. Ellickson is critical of these "bonus" schenes, as are a number of other writers; see, e.g., F. JAMES \& D. GALE, ZONING FOR SALE (1977).

316. See, e.g. Kilduff, supra note 314 (downtown developers angry over proposed transit fee, purportedly to set off additional transit needs created by downtown development). 
tion, when defined as one in which benefits outweigh costs, may involve unfair redistribution, since the individual may lose a great deal even though his costs are outweighed by social benefits. ${ }^{317}$ Perhaps more fundamental is an ambiguity about the ineaning of the external harms that inarket-mimicking regulations supposedly address. Proponents of various market models concede the difficulties of defining "externality;"318 and the pricing of external harms or benefits that, by definition, never appear in a inarket, is an intractable difficulty of the market-mimicking approacl. ${ }^{319}$ So long as the local governmental body decides the definition and price of liarms and benefits, it can mampulate the inarket inodel and exploit the potential for abuse that led to reform proposals in the first place.

Some of these proposals, liowever, do suggest a different method of defining harms and benefits, one using ordinary language understandings of "external harms" and "neigliborliness." 320 But here too, we inay have to fall back on the ordinary language of the very coinunumity whose practices we are attempting to test for fairness. ${ }^{321}$ Thus, whereas plan jurisprudence would ineasure the individual piecenneal change against the community's foreordained plan, market-mimicking proposals would measure it against the community's ordinary understanding of harms and benefits. This hardly advances a counter-redistributive concept of fairness. Planning critics charge that the community's plan may overburden (or underbenefit) certain groups, ${ }^{322}$ but the community's ordinary language or ordinary practice may have the saine undesirable effects.

317. See supra note 310 .

318. See, e.g., Huffman \& Plantico, supra note 309; see also Pelham, supra note 12 (criticizing as unrealistic proposals for regional cost-benefit analysis of local land use decisions).

319. Coleman, The Economic Analysis of Law, 24 Nomos: ETHICs, EcoNomics, AND THE LAW 83, 87-88, 98 (1982). Sagoff, supra note 288, at 1402-10. See also Susskmd \& Weinstein, supra note 237, at 329-30. Richard Posner is unimpressed with the difficulties of pricing goods outside the market, and remarks that judges can inake reasonable assessments of the value of such goods. R. POSNER, THE ECONOMICS OF JUSTICE 61-62 (1981). The example given (a smashed bag of oranges) presents the problem in its simplest form, however. For a discussion of the "intractable" difficulties of measuring something much less tangible-the desire of a crine victim for punishment of the wrongdoer-see $i d$. at 211 . In any event, if judges clo assess the value of matters outside the inarket, a question inust arise about the basis for their assessments. Perhaps that basis is in ordinary language; see infra notes 320-21 and accoinpanying text.

320. Elhickson, supra note 16 , at $728-33$.

321. For an application of the "contemporary community standards" in the definition of obscemity, see Miller v. Califormia, 413 U.S. 15, 24 (1973) (5-4 decision), Hamling v. Unitcd States, 418 U.S. 87, 104-06 (1974) (relevant community is local), and Schad v. Borough of Mt. Ephrain, 452 U.S. 61 (1981) (striking down flat bans on "live entertainment" as overbroad). Ellickson wculd widen the "counmunity" defining "neighborly" or "normal" land uses to a metropotitan community. See Ellickson, supra note 16, at 732. See also id. at 762-64 (proposing metropohitan boards to set standards); Note, supra note 312 , at $472-74$ (proposing that administrative boards assess externalities at standard rates, without specifying nature of counmunity setting standards).

322. See supra note 152 and accompanying text. 
The ordinary language argument, however, does help ensure fairness defined as protection froin surprise. One fundamental reason for using ordinary language as a guide to deciding property disputes is that an average person knows what to expect from ordinary language, since it is unlikely to change by dramatic leaps, though it may change gradually.

Ordinary language then, can be a guide safeguarding the individual agamst unpredictable or anomalous changes. If, despite the coinmunity's prior assurances to the contrary, a lot owner's property is effectively "downzoned" so that open space is the only use allowed, and this is done by an ordinance applied to no other lot in the vicinity, the owner may rightly claim unfair surprise. ${ }^{323}$ Or, if a low incoine housing developer is denied a zoning cliange only because the neighbors fear minority newcomers, he may certainly claim unfair surprise in today's civil rights climate..$^{324}$

Thus, the ordinary language standard suggests that fairness is a - matter of predictability. General planning and the new plan consistency requirements supposedly do protect predictability, ${ }^{325}$ but it can easily be undermined by vague or changeable plans. In a inediation model, the analog to ordinary language or ordimary practice is not so wuch the general plan as the cominunity's established pattern of handling piecemeal changes. This pattern, as Jan Krasnowiecki has suggested, inay be more informative than a "general plan" about a community's probable land decisions. ${ }^{326}$

If fairness depends on predictability, then planning is desirable, as plan jurisprudence holds. Planning docunents, particularly vague and general end-state plans, may not be particularly good bases for prediction. But planning in the nore inodern conception - that is, as continuous and careful reevaluation of resources and goals-inay enhance predictability in the way that ordinary language or ordinary patterns of change do. Rolling planning activities protect citizens from sharp discontinuities in land use control and can give notice to interested parties about the possible piecemeal changes affecting a given property. Indeed, planning itself may improve if the courts see plans not as talisnans to which regulations inust conform, but simply as evidence of

323. Gibson v. Village of Wilmette, 97 Ill. App. 3d 1033, 425 N.E.2d 434 (1981).

324. The court ruled that there was no "taking" under these circumstances in Ohoopee Land Dev. Corp. v. Mayor of Wrightsville, 248 Ga. 96, 281 S.E.2d 529 (1981). Under the foreseeability test proposed here, this case would probably have come out the opposite way, quite aside from possible civil rights violations.

325. Haar, The Master Plan, supra note 100, at 365-66.

326. Krasnowiecki, Planned Unit Development, supra note 104, at 68. See also Krasnowiecki, Zoning Litigation-How To Win Without Really Losing, 1976 Inst. on Plan. Zoning \& EMINENT DOMAIN 1, 4. 
foreseeability. Such treatment encourages cominunities to think ahead and to publicize their intentions, and in fact to weigh how they expect to develop. If they do so, the greater predictability of current inediations can rebut the charge of unfairness.

For example, imagine the developer who is pressed to provide a downtown "pocket park" or a subway entrance to initigate his building's effect on sunlight and traffic conditions. $\mathrm{He}$ is forewarned that such a quid pro quo may be asked if planning studies or inpact analyses liave shown that the community has studied its sunlight and traffic congestion conditions and has thus signaled its concern with the subject, and if its planning studies have identified benefits that inight be a part of a negotiated package. ${ }^{327}$ As one developer commented, he might expect to provide such a quid pro quo as a cost of doing business in the city. ${ }^{328}$

But there is still another step entailed in using predictability as a basis for fairness. One protects oneself against the predictable evil by not participating in the risky venture, by not purchasing the property that needs the seldom-granted zoning change. It is precisely because exit is relatively available at local governmental levels that predictability can test fairness. While predictability makes exit possible, the likelilood of exit acts as a check on local bodies: they will want to act reasonably so that potential developers will not decide that any investment in their community is simply too costly. As one law and economics commentator has observed, land use changes occur in a climate of regulation, and if developers are aware of the climate they can account for it in private arrangements; it is only the unforeseen governmental action that is unfair. ${ }^{329}$ Inplicit in this view, of course, is the presuppo-

327. See Raybestos-Manhattan, Inc. v. Planning \& Zoning Comm'n, 186 Conn. 466, 442 A.2d 65 (1982) (stressing earlier planning activities that gave subdivider warning of the possible requirements and upholding dedications required of subdivider). For planning documents on an array of possible conditions for downtown developinent, see Adams, Limiting the Growth of Downlown High-rises, San Francisco Examiner, Apr. 15, 1981, § 2A, at 1, col. 1 (discussing the City Planning Department's plan, Guiding Downtown Development). For similar proposals in New York, see Dep't of City Planning, City of N.Y., Midtown Development Project 53-79 (1980).

328. Kilduff, Developer Gives $\$ 1$ Million to S.F., San Francisco Chron., Aug. 18, 1981, at 3, col. 5. Developers now routinely design condominiuns along with office space in San Francisco. See Planning Commission OKs 'Pioneer' Highrise, San Francisco Chron., Jan. 29, 1982, at 5, col. 4. They also apparently reckon with the possibility of concessions to low income housing provision and preservation of historic properties. Telephone interview with S. Colm, San Francisco North of Market Planning Coalition (May 14, 1982).

329. Roberts, An Appropriate Economic Model of Judicial Review of Suburban Growth Control, 55 IND. L.J. 441, 462-63 (1980). See also Whittaker v. Zoning Bd. of Appeals, 179 Conn. 650, 661, 427 A.2d 1346, 1352 (1980) ("One who chooses to engage in subdividing land by that decision thus chooses also to be subject to the reasonable regulation of the local planning commission."). 
sition that one who does not like what is going on nay leave or never enter the market in the first place.

Opportunity for exit is not perfectly available even locally ${ }^{330}$-nor need it be, since if exit is too easy, participation as a corrective device for community self-education beconies less likely. Nor is the opportunity for exit evenly distributed. ${ }^{331}$ Outsiders can more easily threaten to "exit" and take their business elsewhere, ${ }^{332}$ while hoineowners and poorer neighborhoods solnetimes participate more readily: psychic investments or lack of resources keep these residents fron Here, of course, voice overlaps with exit, since voice also gives at least limited protection to those who cannot easily exit. But especially where exit is possible, predictability can be a meaningful test of fairness for a jurisprudence of pieceineal changes, as the courts have soinetinnes recognized..$^{333}$

Predictability is not an onerous requirement. There are ways coinmunities can inake pieceineal changes predictable for those who may be affected: they can follow past patterns of change and accommodation; they can explain those patterns over tine through impact reviews; they can explain intended deviations or niajor policy shifts through continuous reevaluative planning. It is such indicia of predictability that the courts should use to test the fairness of any given pieceineal change so as to ascertain whether the parties could have protected themselves by exit, or perhaps, by timely voice.

Thus, just as the courts should look for voice in testing due consideration, so they should look for exit in testing for fairness-most nota-

330. This has been pointed out by Tiebout's critics, who questioned his assumption that residents could move easily among commumities. See, e.g., Buchanan \& Goetz, Efficiency Limits of Fiscal Mobility: An Assessment of the Tiebout Model, 1 J. PuB. EcoN. 25 (1972).

331. On the effects of unequal opportumities for exit at different income levels, see Grubb, supra note 230 , at 24,34 . Hirschman discusses a variety of other "loyalty" barriers to exit, including family or community ties. See A. HiRschman, supra note 23, at 76.

332. See supra note 254.

333. The obvious application is to the land speculator who purchases in the hope of getting permission to undertake some change in existing uses. Courts liave also taken predictability and foreseeability into account in evaluating variances, particularly in denying thein to those who purchase with knowledge of the problematic claracter of a lot. See Note, The Ad Hominein Element in the Treatment of Zoning Problems, 109 U. PA. L. Rev. 992, 993-97 (1961). But liere the courts inay have been insufficiently sensitive to the different opportunities for exit; these decisions may harm the vendor (who cannot sell and who does not want a variance himself, even though he may be entitled to one). Nevertheless, the argument against variances for those who purchase with notice is still inade. See, e.g., Negin v. Board of Bldg. \& Zoning Appeals, 69 Ohio St. 2d 492, 499-500, 433 N.E.2d 165, 170-71 (1982) (per curiam) (Krupansky, J., dissenting); $c f$. Parkway Bank \& Trust Co. v. Village of Norridge, 106 Ill. App. 3d 350, 353, 436 N.E.2d 9, 12 (1982) (those who purchase with knowledge of limitations are im unfavorable position to challenge validity of limitations, although they may prevail where there is no harm to public or surrounding properties). For permutations on the rules concerning purchasers who seek variances, see Bryden, supra note 10 , at 307 . 
bly, for signs that a change was predictable, giving the parties an opportunity to get out of harm's way if they did not wish to bear the risks.

\section{Conclusion: Why Local LANd USE ConTrol?}

In this Article I have atteinpted to link piecemeal land changes to a non-Federalist "alternative tradition" in American political thinking. This tradition legitimizes local decisionmaking by reference to the sinallness of local communities, in contradistinction to the largeness of The Federalist's extended republic. It suggests that the proper inode of ensuring reasonableness, in the sense of fairness and due consideration, is the refinement of the local potential for exit and voice, rather than the attempt to inake a local body act like a court when it cannot act like a large legislature. As the eleinents of a new reasonableness standard, the test of due consideration should be based on popular participation in the steps of a mediation process, and the test of fairness should be based on predictability - the latter test made effective particularly by the opportunity for exit.

Still remaiming is the question of why we so frequently entrust land use decisions to local governments or even to neighborhoods, ${ }^{334}$ where fairness and due consideration cannot rest on Federalist assurances, but must rely on opportunities for exit and voice. Although this subject cannot be fully explored here, if we examine the alternative tradition, we may find some tentative answers.

A standard economic argument for land use regulation is that it prevents adverse "spillover" effects of individual uses, and promotes beneficial uses where individual transactions would not. ${ }^{335}$ Since we have no good way to price the "spillovers" of property uses, ${ }^{336}$ the only tolerable solution nay be to permit communities to make their own property adjustınents, so long as the adjustinents are carefully considered and reasonably foreseeable by individuals who can to some degree choose among communities.

Moreover, it may well be that despite all the official boilerplate of

334. Nelson notes the preference among some citizens for tight neighborhood controls. See Nelson, supra note 15 , at 725,728 . For some neighborhood-based regulations, see SAN FrANCisco, Cal., City Planning Code $\$ \$$ 235-240.3 (1979) (neighborhood "special districts"); U.S. Housing and Community Development Act, 43 U.S.C. \$ 5304(a)(6) (1976 \& Supp. 111 1979) (neighborhood participation in local community developinent programs); Rose, supra note 186 (neighborhood control in historic districts).

335. See, e.g., Heyman, Innovative Land Regulation and Comprehensive Planning, 13 SANTA Clara Law. 183, 209-11 (1972); Huffman \& Plantico, supra note 309, at 16-30; Moore, Why Allow Planners to Do What They Do? A Justification from Economic Theory, 44 J. AM. INST. PLANNERS 387, 390-97 (1978); Tarlock, An Economic Analysis of Direct Voter Participation in Zoning Change, 1 J. ENVTL. L. 31, 34 (1980).

336. See supra notes 318-19 and accompanying text. 
health and safety (and recently, environmental protection) in the preambles of land use controls, the most serious spillovers or externahities of land use fall within the vague field of aesthetics: the way the area looks, sounds, feels, smells. ${ }^{337}$ Reactions to matters of the senses are likely to be limited in physical range; such externahities are most deeply felt within the neighborhood. But there they may be felt very deeply mdeed, for the look of the place may affect the social self-definition of the residents and their sense of control of their hives. ${ }^{338}$ Hence, the economists might say, if land use externahities are primarily matters of aesthetics, then we might expect a constant pressure for regulation at the local level.

But the alternative tradition suggests another reason why these controls are almost always placed in local hands. The symbolic ineanings and values attached to aesthetic tastes vary enormously and are based on polycentric criteria not easily standardized. ${ }^{339}$ It may be that we do not want to entrust decisions about such matters to coalitionbuilding legislatures at all, preferring these decisions to be made by people we trust because we have chosen to live with them, and because we sense our influence on them. ${ }^{340}$ Moreover, we may prefer that such decisions be made individually. It is not enough to trade a shopping center here for an apartment project there; we want individual consideration of each on its inerits. This may also be true of education, the other major subject Americans regularly entrust to local units: we are not willing to make decisions about our children through coalition building, but rather we want particularized consideration of individual proposals by people whose judgment we trust and whom we can influence through consultation. These are decisions where quality inatters especially, and we want them made where we have voice-or the ultimate possibility of exit.

All this is no more than speculation. But if there is anything to it,

337. See, e.g., R. Healy \& J. RosenberG, supra note 4, at 4-5; K. LyNCH, The IMAGe of THE CITY 2-3 (1960).

338. K. LYNCH, supra note 337, at 2-3, 123-28; C. PERIN, supra note 285, at 188-93.

339. Williams, Subjectivity, Expression, and Privacy: Problems of Aesthetic Regulation, 62 MinN. L. Rev. 1, 16-21 (1977). The term and concept of polycentricity are developed in M. PoLANYI, THE LOGIC OF LIBERTY 114-22, 170-79 (1951).

340. C. PERIN, supra note 285 , at $188-92$. This may also be the case in countries nominally much more centrally governed than the United States. In France, local officials often hold several offices simultaneously, in different levels of government, and are thus able to use their influence at the center to satisfy local needs. See France, U.S. Grapple with Decentralization, San Francisco Chron., Mar. 3, 1982, at C-3, col. 1. I recently had occasion to speak with a law professor who was teaching Baurecht (roughly, construction law, including land use planning and regulation) at the University of Cologne. Despite Germany's quite detailed federal statutes concerning land planning and development, the opimion of this teacher was that "everything gets settled over a glass of beer in the Ratskeller [city hall bar]." Interview with Karl-Heinz Böckstiegel in Cologne, West Germany (May 14, 1982). 
we will be dealing with substantial local influence over land use decisions for a long time to conne. That this local influence requires some safeguards beyond legislative coalition building was the main contribution of plan jurisprudence. But the principles that we use to guide local land use controls should bear some relation to an underlying rationale for local government. This Article has ineant to suggest what that rationale might be and some of the principles that follow from it. 